\title{
Geografia Virreinal del Peiú: La Audiencia de Lima en el siglo XVIII
}

\author{
(Continucición) \\ DESCRIPCION DE LAS PROVINCIAAS DEL OBISPADO \\ DE HUAMANGA (24)
}

El Osispsodo de Huamangla, fundado en 1609, comprende ocho Provincias que son: la de su nombre, Huanta, Angaraes, Castrovirreyna, Lucanas, Parinacochas, Vilcashuaman y Andahuaylas. De la primera es Capital la Ciudad de Huamanga (25), fundada en nueve de Enero de 1539 por Don Francisco Pizarro con el nombre de San Juan de la Frontera, por hacer írente a los Indios de la Montaña. Después tomó el de San Juan de la Victoria, por una que se ganó en aquel paraje. Está situada en $12^{\circ} 54^{\prime}$ de latitud austral, en un dilatado terreno de temperamento benigno, y sano, pues mi el frío ni el calor molestan en tiempo alguno y viene a ser todo el año una deliciosa Primavera. Sus edificios son de cal y piedra con cubiertas de Maderas de los Andes, que están poco distantes, en que abundan los cedros. Las Calles anchas, las Plazas Cuadradas y las entrcdas a fa Ciudad muy alegres $y$ vistosas por la abundahciag de Huertas ly Arboledas." Corre un arroyo grande inmediato a la Ciudad, de buena agua, y a un cuarto de legua un Río, que cesagua en el de la Pangora, y éste en el de la Sal, que finalmente entra en el antiguo Marañón. Tiene esta Ciudad Cabildo Seperior, compuesto de dos Alcaldes Ordinarios, Regidores, Alferez Rea! y demás Oficios que preside un Corregidor. Entre sus Vecinos, que llegan a 2,503 almas, se cuentan algunas familias distincuidas por su antigua ncbleza. Su Catedral de tres naves es espaciosa y bien adornada. Además del Obispo, tiene tres Dignidades: Deán, Arcediano y Chantre; dos Canongías, que por los años de 1686 mandó su Majestad fuesen de Oposición: una Magistral y otra penitenciaria; y dos Raciones. Tiene unido a dicha Iglesia el Colegio Real de San Cristóbal con

(24) El Conocimiento de los Tiempos. Año 1767,27 pp. s.f.

(v. pp. 9).

(25) Aciual ciudad de Ayacucho. 
el privilegio de conferir grados mayores, con título de Universidad; aunque por no acturase sus Cátedras, se ven precisadcs los Vecinos a enviar a sus hijos a otras Universidades del Reino para instruírse. Aunque en otros tiempos se extendía la jurisdicción del Corregidor de esta Ciudad a las Provincias inmediatas, hoy es muy limitada, pues en sus contornos sólo tiene dos Pueblos. Confina por el Norte y Nordeste con la Provincia de Huanta; por el Sur con la de Vilcashuamán; y por el Oeste con la de Castrovirreyna. Comprende cuatro Curatos; dos en la Ciudad, uno de Españoles y otro de Indios; aquél en la Catedral, y éste de Santa Ana. Lo manejan los Prebendados desde su erección, poniendo Sacerdotes para la Administración de Sacramentos. El III, que pertenece a la Ciudad, es el de Santa María Magdalena. Se compone su feligresía de Indios nativos, que aunque viven en diferentes barrios reconocen a este Cura. Tiene dos anexos que son: Chiara y Santa Bárbara de Neque, a tres leguas de la Capital. El IV es el Curato de Anco, distante 20 leguas, debiéndolas atravesar para llegar a él por la Provincia de Huanta. Compónese de cinco Pueblos que son: Anco, Anchihuay, Rapi, Chinquinrilca y Chungay. Los referidos Pueblos, aunque en temple frío, gozan de frutos de la Montaña de los Andes, por tener sus habitadores algunas haciendas en ellos, con los cuales confina este Curato por el Este. Allí cultivan Coca, Cañas de Azúcar, Maíz y algunas hortalizas; su terreno es fertilísimo, pero lo es también de insectos molestos: de Culebras, Víboras, Alacranes, lo que es común a toda la Montaña. De ella sacan los frutos, que hemos referído en otras partes, como Plátanos, Paltas, Chirimoyas, Huayabas, Piñas de exquisito gusto, Naranjas, Limones, etc. Este Curato se llamó en ofro fiempo de Mayocmarca, del pueblo principal oue estaba en el Valle de este nombre, dentro de la Montaña. Plún subsistía a fines del siglo pasado. Dícese que sus habitantes se retiraron a los otros pueblos, ahuyentados de los Tigres. Tienen todo este Curato 1,200 almas que con las de los tres referidos hacen 3,700. Hay en la Ciudad cinco Conventos: Santo Domingo, San Francisco, La Merced, la Compañía y San Juan de Dios con Hospital. Hay también dos Monasterios de Monjas: Santa Clara y Santa Teresa. Tres Hospicios: de San Agustín, San Francisco de Paula y de la Buena Muerte. Al Norte de ésta se halla la

\section{PROVINCIA DE HUANTA.-}

Confina por el Nordeste y Norte con la Provincia de Jauja; por el Nordeste y Este con las Montañas de los Andes; por el Sur y Sudoeste 
parte con la de Angaraes, parte con la jurisdicción de Huamanga y Castrovirreyna; por el Sudeste toca a la de Andahuaylas. y Vilcashuáman Le dan de largo desde la Cruz de Tayacaja, confín de la Provincia de Jauja, hasta la de Andanuaylas 60 leguas, Noroeste-Sudeste y 40 de ancho. La situación de esta provincia es por la mayor parte en altos o medias Punas, en que hay algún frío. Lo restante en quebradas templadas y aún calientes; pero es bien escasa de pampas o llanuras. Cultívase en ella todo género de frutos y semillas, como también Cañaverales de Azúcar. Hacia aquella parte que confina con la Montaña, se coge bastante Coca y las Frutas y efectos mismos que se han dicho en el Curato de Anco de Huamanga, por donde sigue hacia al Sur. Hay en esta Provincia crías de todo género de ganados, aunque no en la mayor abundancia. Hacia la montaña hay varias haciendas pertenecientes a los Curatos de San Pedro de Huanta y de San Juan de Tambos en donde se coge la Coca, cuya cosecha se hace tres veces al año. Los Andes de Osór y quebradas de Saniihurylas son de Canta. Las quebradas de Tamboconga y Buenalerma de Tambo. Llega al año la Coca que fructúan a 8,300 arrobəs, de a 32 libras, que se llevan a Huancavelica y otro Minerales, y se vende a ocho pesos la arroba. Este es el principal género de comercio de esta Proyincia. En los Bosques y Selvas de la montaña hay muchas particularidades de que, como he dicho, se ha dado noticia en otras partes, como son: Sangre de Drago, Canela, Azeyte de Niaría, Miel de Fubejas, quetseChallan en los lTroncos de los Arboles, algunos tan gruesós que Thocpuedeh abarcarlososeis ni ocho hombres. También crían las Abeias debajo de tierra. Hay Tigres de piel más hermosa quie los de Europa, Gatos monteses, Osos, Erizos, Jabalíes, Vacas y Cáballos moritaraces, Pavos, Palomas, Perdices; un árbol llamado Pilco cuya sombra causa una hinchiazón universal del cuerpo, de que mueren los que llegan a ellos, y finalmente muchas yerbas raras que pueden servir de ocupación a la Botánica. En esta Provincia apenas hay una u otra mina de plata de poca entidad. Hay una de plomo y un abundante mineral de Sal, que se lleva a los minerales de las Provincias inmediatas para beneficiar la plata. Entre los Ríos que hay en esta Provincia, el mayor es el que baja por la de Jauja. Nace en la de Tarma, de la läguna nombrada Chinchaycocha. Todavía conserva el nombre de Marañón, que se le dió al principio de la conquista, aunque en la lengua de los Indios conserva el de Angoyaco. Divide esta Provincia de la de Angaráes, y haciendo una inflexión desde el Sudoeste al Este forma una Península, que llaman Isla de Tayacaja. Después, engrosado con las aguas de los Ríos de las Provincias vecinas y de otras 
distantes, entra er la montaña y desagua muy caudaloso en el Maraán del P. Fritz y Condamine con el nombre de Ucayali, a más de 150 la guas de esta Provincia. Cría muchos y muy grandes peces, que pescan los Indios gentiles a flechazos. Para pasar de la Provincia de Angaráes a ésta tiene un puente firme, por donde va el carnino real del Cuzco; llámase el puente Iscuchaca; y oiro de Criznejas en el otro lado de la isla en el Puéblo de Máyoc. Los hábitantes de esta Proviricia llegan a 10,000 de todis edarles y sexos.

Comprende esta 12 Curatos. El I es el de San Pedro de Huanta, Capital de esta Provincia. Estít a seis lezuas de la Ciuded de Huamanga, hasta cerca de la cual llega la jurisdicción de esta Provincia. Para pusar a aquella hay un puenle de maromas de moderra constricición en el Río que llaraan de la Pangora. Tiene este Curato dos anexos que scn: Vivovivo y Cano. El II es el de San Antonio de Luricocha. T:ene dos anexos que son: Seque y Huayllay. El III es el de San Juan de Tambos. Tiene tres anexos que son: San Juan de Chilcas, San Migun y San Salvador de Osno. El IV es el de San Juan de Huama iguilla $T_{1}$ ne tres anexos, que son: San Marcos de Cihua, Pacayasa y 1 íacachacra. El $V$ es el de Quinua. Tiene dos anexos que son: Huaychao y Vinchos. El VI es el de Tambillo. Tiene dos anexos que son: Necineluayocindor y Acccro. El VII es el de Ticllas. Tiene seis anexos que son: Vinchos de la Sal, Socos, Paccha, Piccha, Santiago y San Peatr de la Sal. El VIII es el de Máyod. bTiene cuattodadexos que Son: Ch ni:mpa, Ayari, Paucarbambilla y Iogroja.P Fl $\mathrm{H}$ es el de Paucarbamba. Tiene cinco anexos que son: Hunchos, Santa Clara de Cosme. Cotay, Santiago de Tucuma y Anco. El X es el de Colcabamba. Tiene tres arrexcs que son: Ocoro y Tocllacuri, y en la ceja de la moniaña, a la otra parte del Río Angoyaco otro pequeño pueblo nombrado Anchac. El XI es el de San Pedro de Pampas. Tiene dos anexos que son: Huallua y Acostambo. El XII es el de Huaribamba. Tiene ocho anexos que son: Salcabamba, Santiago de Picchos, Roccha, Tongos, lla, Ayaycocha y, en la ceja de la montaña, Surcobamba y Huachucolpa. Estos cinco Curatos últimos están en la Isla de Tayacaja. Esta Provincia se llamó en otro tiempo Azángaro de Huamanga. Al Sur sigue la

\section{PPOVINCIA DE ANGARAES.-}

Esla Provincia está como enclavada en la de Castrovirreyria desde el Sudoeste hasia el Nordeste, así como ella abraza la Isla de Tayacaja de la de Huania. Toca por el Oeste un poco a la Provinzia de Yauyos, 
quə se introduce entre la de Castrovirreyna y de Jaujz, con quien tamtlén sonfina algo por el Noroeste. Tiene 24 leguas $d \ni$ inicso de Este a Oeste y 12 de ancho, con bastante iregularidad en su figura. i-1 Capitei de esta Provincia fué el Pueblo de Acobamba; pero por estar el Gobernacini y gente principal en la Villa de Huancavelica, se repizta por Capital ésta, residiendo en aquella un Teniente. Su temperamento es por la r:ayor parte frío, a excepción de una u otra quebrada que snn algo ternpiadas. Con todo, considerada en general no es escasa de Trigo, Maíz y demás semillas, pues sólo en la jurisdicción del Curato de ^ropbamka se cogen regularmente 25,000 fanegadas de Trigo al año, de que se atas!ece dicha Villa. Cultívanse también, en los parajes templa dos, Cañaverales de Azúcar y algunas frutas y verduras. Cuídase tam. bien una especie de Heno, que llaman Ichu, el cual sirve de leña para los hurnos en que se seca el Azogue. Esta yerva deja no poco provechc, purque la pagan bien los mineros. Críanse ganados de todo géne:c y Carnercs de la tierra que sirven para acarrear los metales del Coric a los hornos. En el Pueblo de Pallalla es tradición que hay mira de Carbón, que por no usarse en este Reino está olvidada. En el Distrito del de Jucamarca hay algunas minas de plata que se trabajan aunoue con poca utilidad; y cerca de Huancavelica las hay también, pere de poca ley. También hay de Cobre puro. A un lado de la Estarcicia del Pueblo de Acobamba, se ven unas piedras a manera de Pirám:des; y en algunàs, lábrádos unös assientos como Canapees, que ha maltratado el tiempo. Allí están de antes de la Conquista. Hállanse tanibion en esta Provincia varias Tierras, que sirven para pintar, como sor, la Sombra, que llaman de Huancavelica, Oropimente, Ocre, Almayre Cinabrio y otras de otros colores. Los Ríos que la bañan son el Angoyaco, de cuyo origen hemos dado razón en las descripciones de otras Provincias, el cual divide esta Provincia de la Isla de Tayacaja, He:'cneciente a la de Huanta. El de Vilcabamba, pequeño, que la divide de la Jauja; el de Lircay; el de la Sal; todos los cuales entran en ei $r$ n oyaco o Marañón. En los mayores se cogen Bagres y Pejerreyes. El de la Sal divide el Curato de Julcamarca de la jurisdicción de Huanta. La Capital de esta Provincia, como se ha dicho, es Huancavel:-a. Esta Villa, nombrada en otro tiempo Villarica de Oropesa, es un iugar de los más considerables del Perú, por hallarse en ella la mina te Azogue, que es el alma de todos los minerales del Reyno. De cubrióse en 1563, y se registró a primero de Enero del de 64 . Se iı:ndó esta Villa a cinco de Agosto de 1572 por Don Francisco de Toleào, hijo de los Condes de Oropesa, Virrey de estos Reynos. Está si- 
fuztia a 12" 48 $24^{\prime \prime}$ de latitud austral, distante del mar por donde mejics 40 leguas. Su posición es en una media quebrada que hace la ccrdillera; por lo cual su temperamente es bien frio, su cielo inconstante todo el año, llueve unos dias y otros hiela, y aún uno y otro en un mismo día, a veces con tempestades, granizo y rayos. Sus fábricas son de una piedra más o menos porosa, en que se congela el agua caliente de unos manantiales que hay en su contorno. Baña a esta Villa un arroyo, en tiempos de lluvias es bien caudaloso, porque se le agregan otros que descienden del Cerro inmediato. Para comunicarse unos barrios con otros hay varios Puentes, una de ellos de canteria con tres arcos, otra de dos piedras, sin labrar, unidas. Pesiden en esta Villa un Gobernador, que es Superintenclente de la mina, dos Oficiales Reales, Allguacil mayor y un Regidor Procurador de la Villa. La Mina no se trabaja de cuenta de Su Majestad sino por un gremio de Mineros, que entregan todo el Azogue que sacan en la Real Caxa, abonándoles el Rey un determinado precio por cada quintal. El número de Mineros es de 40 , que no está siempre completo, porque por los muchos meta. les que se han sacado en estos 200 años y la profundidad de las labores, ha ido en decadencia la mina y consiguientemente sus utilidades. Hay en los contornos de la Villa 124 hornos de beneficiar Azogue, y la boca dista de ella como una legua.

Comprende la Provincia seis Curatos: cuatro pertenecientes a la Villa y los restantes en 10 demás de la Provincial $S E I$ I y principal es el de San Antonio, en csuggurisdicción lhayonnucha (Clerecía. Tiene al otro lado del Río un anexo, nombrado San Cristóbal. El II es el de San Sebastián. Tiene dos anexos que son: La Asunción y Sacsamarca. El III es el de Santa Ana, con un anexo nombrado Huaylacucho. Aquí se labran todas las basijas de barro vidriado, que sirven para la extracción del Azogue. El IV es el Curato del Cerro de Santa Bárbara, que es el del mineral. Tiene dos anexos. El uno en el brocal de la mina, nombrado San Francisco; y el otro en su contorno, nombrado Chacllatacana. Como esta Villa es de bastante comercio, llegan los habitadores a 8,000 , siendo un poco menos los de lo restante de la Provincia. El V Curato es el de Acobamba. Tiene cuatro anexos que son: Espiritucaja, Todos Santos, Andabamba y Pucará. El VI es el de Acoria, tiene cinco anexos, que son: Huando, Palca, Añancusi, Pallalla y Chitpaca. El VII es el de Conaica. Tiene cuatro anexos que son: el de Puente del Iscusliaca, Cuenca, Moya, Vilcabamba y Acobambilla. Cerca de Cuenca hay un manantial de agua caliente. El VIII es el de Lircay. Tiene seis anexos que son: Huayllays, Ucchuhuayllay, Callanmar- 


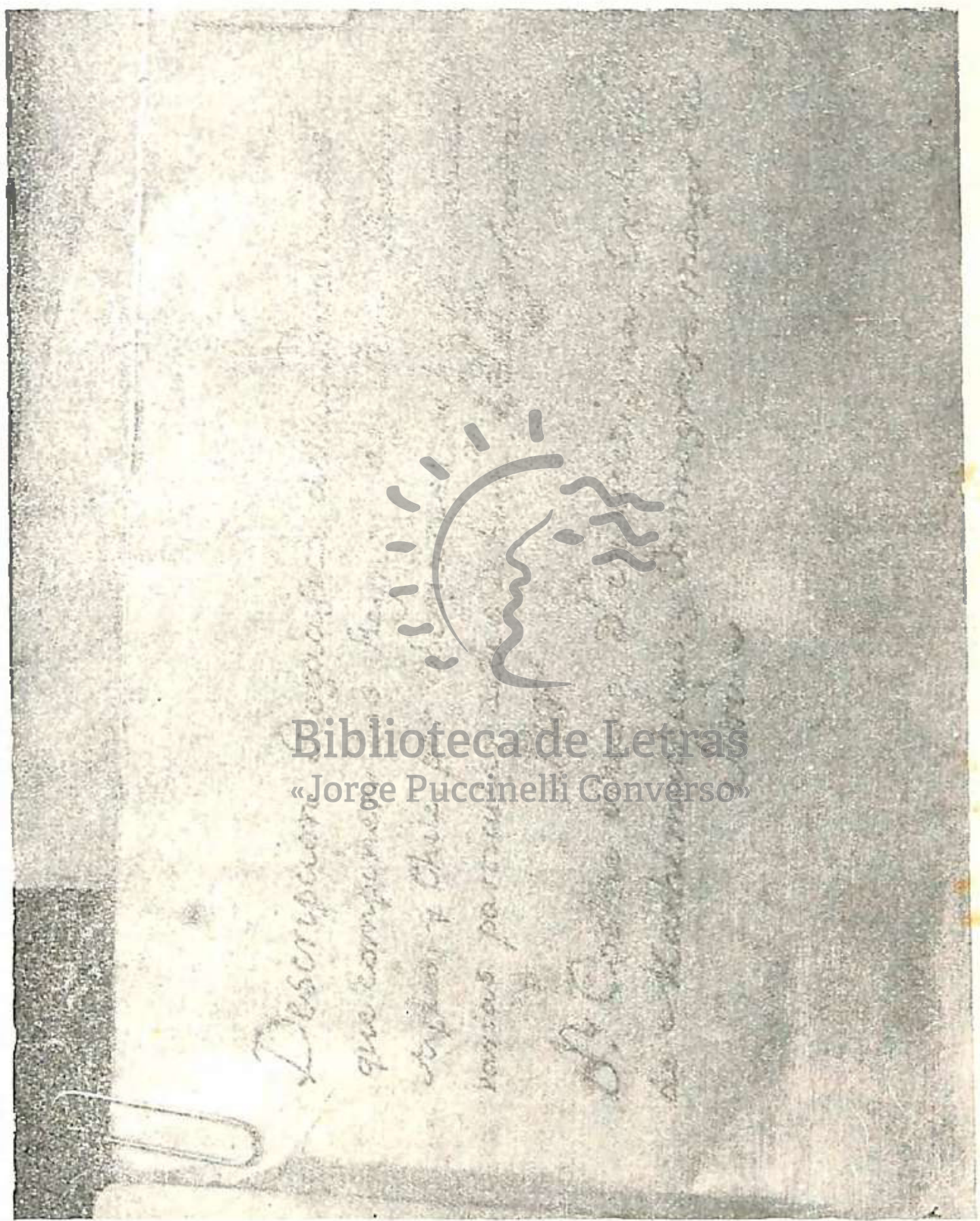

Pertada del manuscito de don Cosme Bueno (copia del siglo XVIII, existe en la MENIORIA PRADOI, 


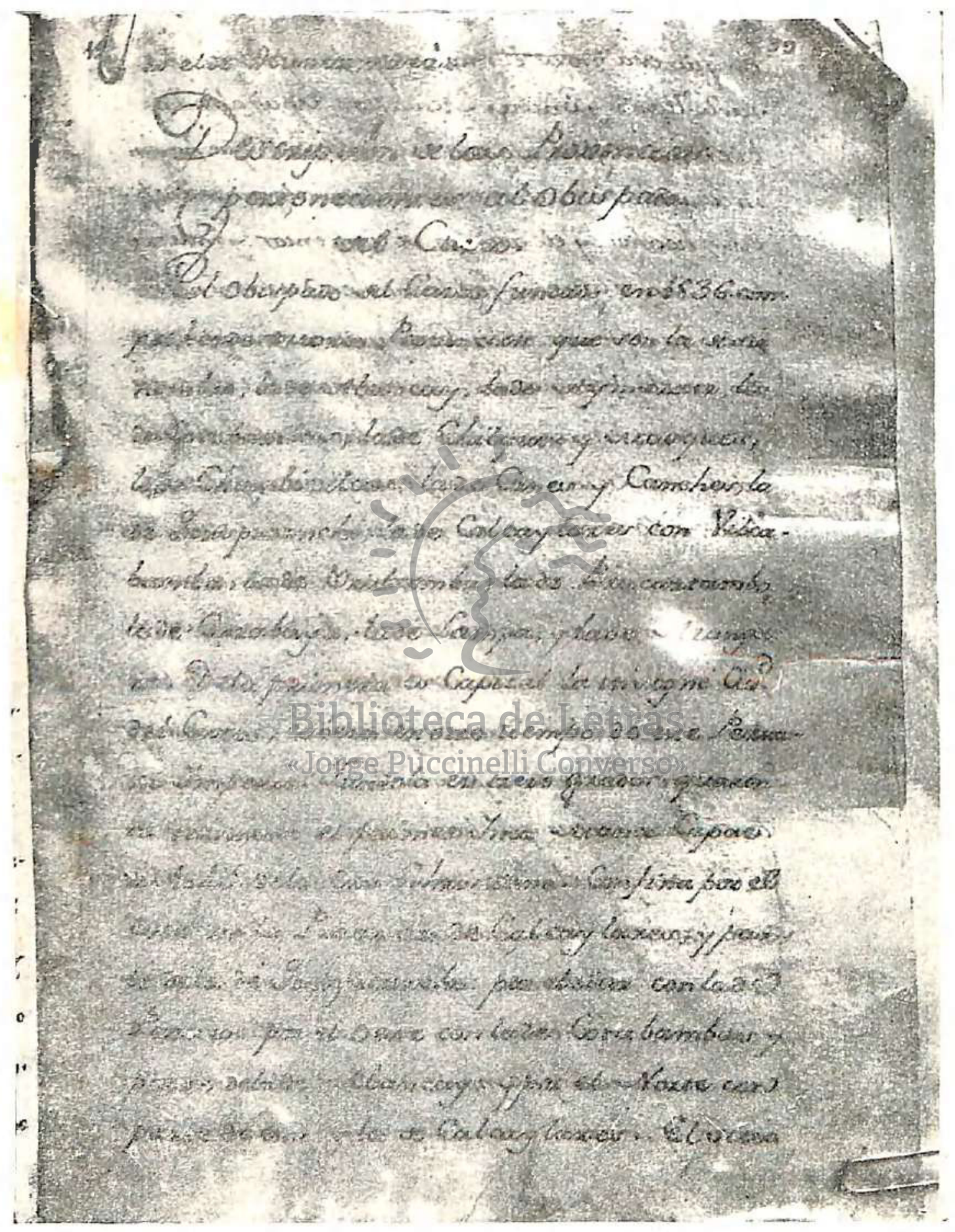

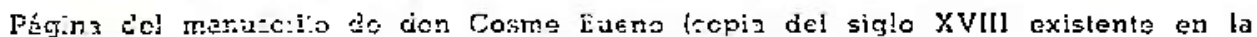
M MOEIA PRADO). 
ca, Huancahuanca, Huachocollpa y Anchonga. En Huayllay hay un Crucifijo muy milagroso y muy venerado de todas aquellas comarcas. El IX es el de Julcamarca. Tiene cinco anexos que son: Congalla, Pata, Antarpanco, Llillinca e Incahuasi. Estos dos últimos Pueblos pertenecen à la jurisdicción Real de la Provincia de Castrovirreyna. En el de Pata se han aplicado los Indios a la Carpintería y trabajan Mesas, Cujas, Escaños, Sillas, etc., que venden en esta Provincia y las vecinas. También en el distrito de este Curato hay un pueblecito nombrado Toyca, que pertenere a la de Huanta. A la parte del Sudoeste sigue la

\section{PROVINCIA DE CASTROVIRREYNA.-}

Confina por el Noroeste con la de Cañete; por el Norte con la de Yauyos; por el Nordeste con la de Angaráes, y algo con la jurisdicción de Huamanga y Huanta; por el Este con la de Vilcashuaman; por el Sudeste con la de Iucanas; por el Sur, Sudoeste y Oeste con la de Ica. Es fragosa y estéril, y por esto apenas llegan sus habitantes a 6,900, siendo así que de Poniente a Levante tiene 22 leguas, y de 35 a 40 de Norte a Sur. No hay en ella minas descubiertas, ni más caminos que los que cada uno se abre por donde le permiten las nieves y las corrientes de muchos arroyos, que precipitados se encuentran a cada pa so, especialmente en tiempo de aguas, que es desde Octubre a Mar. zo. Los frutos de estalProvindiason Trigo, Cebada, SMaíz y Papas. En una u otra quebrada, menos fría se dan algunas frutas, aunque no de toda especie. Lo que no abunda poco son ganados por la abundancia de pastos. Hay también Llamas o Carneros de la tierra, Vicuñas, de que se aprovecha la lana, y Huanacos. Riéganla algunos Ríos, de los cuales unos bajan por las Provincias de la Costa al Mar del Sur, y otros por el otro lado de la Cordillera se encaminan a las Provincias Orientales y van a parar por fin siss aguas por el Marañón al otro Mar en que desagua este río. El de Cañete toma aguas de esta Provincia, y nace en ella el de Chincha. De una laguna nombrada Orcococha toma origen el río Pisco. También sale de esta Provincia el de Ica. De otra laguna, nombrada Choclococha, sale el Río Calcamayo, que entra en la Provincia de Vilcashuaman. Estas lagunas, aún con ser grandes y navegables, no crían pescacio alguno por el sumo frío de los parajes en que se hallan.

Comprende esta Provincia seis Curatos. El I es el de la Provincia de Castrovirreyna, capital de la Provincia. Tiene una Parroquia dedicada a San Roque, y tres Pueblos anexos que son: Cinto, Sacsaquero y 
Huacahuaca, y dos Haciendas con Iglesias, nombradás Huallanto y Huallanga. El Ii Curato está en la Cordillera de Pilpicheca, y por eso éste se concce mejor por Curato de los Cerros. Este Curato tiene tres anexos que son: Cargcnacho, Santa Ana y Acostamba. Hacia esta parte se hallan los Fueblos de litllirta e Incrinuasi, que auncuo son de esta Provincia pertenecen en lo espiritual al Curato de Julcamarca de la de Angaráes: Asimismo se hallan los Pueblos de Vilcapalca y Atunsulla, que del mismo modo son del Curato de Totos y Paras de la de Vilcashuaman. El III Curato es el de Córdova. Tiene ccho anexos que son: Ocohamha, Ayanarca, Ocoyo, Lamari, Pacomarca, Querco, Laramarca y Quirahuara. El IV es el de Huaytará. Tiene siete anexos que son: Tambillo, Ayavi, Tambo, Capillas, Sangayayco, Andaymarca y Santiago. F,! $V \Leftarrow s \in$ l de Huachos. Tiene dos anexos que son: Chiris y Cocas, y la estencia de Paurange con Iglesia. El VI es el de Arma. Tiene seis anexos que son: Cotas, Huanactambo, Huanaco, Cacrillo, Yanac y Tantará. Los tres primeros pertenecen a la jurisdicción de la Provincia de Yauyos. Demás de estos pueblos tiene esta Provincia en su jurisdicción otros, que son anezos del Curato de Chupamarca de la de Yauyos y son: Huácar, Chavín, y dos Estancias: Huanca y Huañupisa. También el Curato de Víñac, que es de la de Yauyos, tiene estos cuatro anexos que son: Huangasca, Tana, Ongos y Claca. Poro se debe advertir que los que no son de esta Provincia y van de letra cursiva pertenecen al Obispado de thuamangas A la parte del Sudeste de esta está situadádeluccinelli Converso"

\section{LA PROVINCIA DE LUCANAS.-}

Confina con el Norte y Noroeste de Castrovirreyna; por el Este y Sudeste con la de Parinacochas; por el Nordeste con la de Vilcashuaman y Andahuaylas; por el Sudoeste y Oeste con la de Camaná. Ie dan 60 leguas de largo, 30 de ancho y por algunas partes 12 . Su situación es entre los empinados Cerros de cordillera con muy pocos llanos y ésos cortísimos. Su temperamento, como todos los de Sierra, frío todo el año. $Y$ así sus frutos se reducen a Papas Ocas, Cebada, Trigo, Maíz, y en algunas quebradas Semillas y verduras; especialmente en las que miran a la parle de Camaná, en que se cultivan algunos árboles frutales: Duraznos, Higueras, Manzanos y otros, pero de modo que a excepción de la carne, necesitan entrar víveres de otras Provincias para la subsistencia de la gente que trabaja en sus minerales. Aun el ganado no abunda como en otras. Junto al Puéblo 
de Larray del Curato de Scras, hay un manantial de agua caliente, muy medicinal. Su calor es excesivo. No hay en ellas más Haciendas ce consideración que las de moler metales de plata. Por razón de ésta, tiene algún comercio con las otras; pues si faltaran las minas descaeciera la gente y aun las inmediatas no tuvieran fácilmente donde exponer sus afectos. A excepción de algunos ärroyos, no tiene esta Provincia más de un Río grande, el cual se incorpora con el de Vilcashuaman. Cćgense en él algunos Bagres. Lo que da todo el ser a esta Provincia son las Minas de plata, las cuales se hallan cerca del Pueblo de San Juan, anexo del Curato de Lucanas. Diez son las principales veias, que están descubiertas y trabajadas, unas hasta la profundidad de 50 estados, otras de 60 y algunas de 80 . El beneficio de estos metales se hace con Azogue y Sal, ayudándolo con Alcaparrosa, gue en este Reyro llaman Colpa. Ista keneficio lo descubrió Don Lorenzo de la Torre, dueño que fué de las principales vetas. El cual se ha establecido en muchas otras Minas del Reyno, en que los metales son de la misma o de poco diferente naturaleza. Lo que frucifican o producen cada año son de 20 a 25 marcos de Plata. La veta que más no excede de ocho marcos por cajón, y la que menos cuatro. Produjeran mucho más si hubiera gente correspondiente para el trabajo, pero la Provincia tiene pocos Indjos proporcionados para él. En toda ella incluso les Españoles y Mestizos, que son muchos por causa de las Minas, apenas pasantsushabiadorestae 90,000 de todas edades y sexos.

Comprende esta Provincia 14 Curatos. El I es ell de Lucemas. Tiene cinco anexos que son: San Juan, San Cristóbal, el asiento de Viseca, el de Acola y el de Utec. El II es el de Otoca. Tiene tres anexos que son: Uruaysa, Palco y la Concepción. El III es el de Laramate. Tiene cuatro anexos que son: Ocoña, Llauca, Carhuacucho $y$ Huacas. El IV es el de Cayza; tiene cinco anexos que son: Santa Lucía, Uychuyłambo, Huallhua, Tamboquemado y Uschuymarca. El V es el de Pucquio. Tiene cinco anexos que son: San Andrés, Chilquez, Santa Cruz, Sar Pedro y Santa Ana. E! VI es el de Parayfancos. Tiene tres anexos que son: Chavina, Para y Concepción de Caja. El VII es el de Cabana. Tiene tres anexos que son: Sondondo, Andamarcas y Huaycahuacha. El VIII es el de Abucara. Este Pueblo era en otro tiempo Capital de esta Provincia, y aun le daba el nombre. Tiene tres anexos que son: Ishua, Chacralla y Pampamarcia. El IX es el de Soras, con un anexo nombrado Carcay. El X es el de Huacaña. Tiene tres anexos que son: Choschama, Morocolla y Tintay. El XI es el do 
Payco. Tiene dos anexos que son: Paucará y Matará. El XII es el de Quercbamba. Tiene tres anexos que son: Poma, Quixe y Chilcayo. El XIII es el de Cahuanca. Tiene dos anexos que son: Belén y Chalcos. El XIV es el de Chipau. Tiene dos anexos que son: Queca y Moyobamba. Al Sudeste sigue la

\section{PROVINCIA DE PARINACOCHAS.-}

Confina por el riorte con la de Aymaráos; por el Noroeste con la de Andahuaylas; por el Nordeste con la de Vilesshuaman; por el Este ccn la de Chumbivilcas; por el Sur con la de Condesuyos de Arequipa; y por el Oeste con lä de Lucanas. 'Tiene de largo NordesteSudcesie 35 leguas y 22 por el contrario rumbo, con irreguralidad bestarie como tocias las de la Sierra. Ella es toda en Serranía, en que se experimenia intenso frío a excepción de algunas quebradas en que por lo beniguo del temperamento hay todo el año Peras y todas las frutas del Reyno menos Chirimoyas, esto especialmente en el Pueblo de Pausa. En lo demás se coge Trigo, Maiz, Cebada, Habas en abundancia y algunas otras semillas. Por la abundancia de pastos hay bastante Ganado, en especial de Lana, de que tejen ropas que llaman Chulpas, Cumbes y Llicllas, de hermosos matices, para lo cual cultivan muchos plantíos de grana, que llaman Magno. Críanse en los cerros muchos Huanacos, que sitven comogumentos para conducir cargas no muy pesadas, comojlas de los dichos telidos y otros. En el Curato de Pullo hay varias minas de oro, que se beneficia por Azogue. Su ley es varia, por lo que no es fácil computar su utilidad. Lo que hay de cierto es que son muchas las labores yn se emplea mucha gente; y así es considerable $e l$ beneficio, aunque en pequeñas cantidades. En el Pueblo de Chaypi se veneraba de tiempo inmemcrial una milagrosa Imagen de Nuestra Señora del Rosario, cuyo templo habiéndose quemado pocos años hace, perdiéndose por esta desgracia aquel venerable Simulacro, se ha puesto otro bellísimo en que vinculan su mayor consuelo aquellos fieles. Es dávida del Marqués de Selva Alegre. Presidente que fué de Quito. A su fiesta concurre mucha gente de varias Provinclas. En el Chumbi hay otro Santuario muy célebre de Nuestra Señora de la A. sunción, que en lienzo manifiesta ser de pincel muy diestro. Dícese que fué dádiva de un Papa a un Curi de este Pueblo, que hizo viaje a Roma. En el Curato de Lampa y en el de Coracora, hay manantiales de agua caliente. Cerca del Pueblo de Huarhua se halla un cerro de Sal, de que se abastecen varios Minerales de Plata de otras Provincias. Hary en esta 
Provincia una laguna de siete leguas de circuito sobre una de ancho. Críase en 'ella una especie de pájaros blancos y colorados, que en lengua del país se llaman Paniura, de cuya voz corrompida y de Cocha que es laguna, viene Parinacochas, nombre də esta Provincia. Muchos de sus habitantes, tanto Indios como Mestizos, tienen el ejercicio de A-ieros. Llevan de la Provincia de Camaná al Cusco y otras partes Vino, Aguardiente, Aií, Aceitunas, Pescado seco y Camarones, en cambio de Cecina, Sebo, Papas, Chuño, y Ropas, de las que se dijeron arriba. Los habitantes de esta provincia llegan a 11,300.

Comprende 14 Curatos. El I es el de Coracora, sin anexo alguno. El Il es el de Chumbi, con un anexo nombrado Ácos. El III es el de Puito, con un anexo nombrado Chaypi. El IV $E s$ el de Pararca, con un anexo nombrado Quilcata. El V es el de Pausa, con un anexo Caciri. En Pausa han tenido su asistencia los Corregidores, y así deje tenerse por la Cipital de la Provincia. Aquí hay un Cerro muy alto, que dicen encierra muchai riqueza. El VI es el de Lampa. Tiene tres anexos que son: Huataca, Cascará y Rybacazco. El VII es el de Pacca con tres pueblos: Ampi, Pausa y Opahuacho. No hay en este Giralo Puejlo llamado Pacca. Húbolo en otro tiempo, hoy el principal es Huanacmarca. El VIII es el de Colta, con un anexo nombrado Alpabamba. El IX es el de Oyolo. El X es el de Corculla. El XI es el de Zayla. Tiene un anexo en la Provincia inmediata de Condesuyos de Ârequipa. El XII es el de Charcana, con un anexo nombrado Andamarca. Tuvo esle Curato dos anexos más, que son: Belinga y Quechualla, Dos Cuafes pertenecen alapresente al Curato de Salamanca de la Provincia de Condesuyes de Areguipa. El XIII es el de Pampamarca. Tiene dos anexos que son: Huarhua y Mongruy. EI XIV es el de Huaynacotas, con un anexo nombrado Tauritma. Por la parte del Nordeste sigue la

\section{PROVINCIA DE VILCASHUAMAN.}

Confina por el Norte con la Provincia de Huanta y jurisdicción de Huamanga, hasta cuyas goteras llega su jurisdicción; por el Noroeste con la de Castrovirreina; por el Sudoeste con la de Lucanas; por el Este y Nordeste con la de Andahuarylas. Su figura es la de una quebrada larga de 24 leguas Sudoeste-Nordeste y 18 de ancho. Corre por ella un Río, nombrado allí Calcamayo, que a la salida es caudaloso por juntársele muchos arroyos, que de una y otra parte le bajan de las Punas. Este Río nace en la laguna de Choclococha en la Provincia de Castrovirreina. En algunas partes se pescan Bagres, especialmente al llegar a la Provincia 


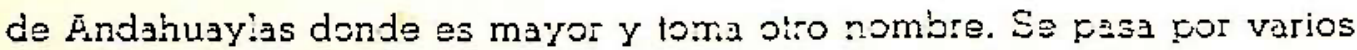
puentes de criznejas, hethas de uni esperie de mimijres, como son muchas del Peyno. Toma el nombre esta Provincia de un Cerro o tierra muy alta, llamada así, donde hay vestigios bien c'aros de una gran Plaza de Armas, cercada por los antisuos habitadores de este Reyno, de piedras de Sillería, y enfrente unas ruiras de un templo dedicado al Sol, obra toda que podría dudarse fuese de Indios, y da a presumir sea de otra nación anterior, sobre que no falta quien piense flieron Gigantes, por ser hechos estas obras, de cuyo gériero hày otras en el Reyno, de piedras de enorme magnitud y traidas, segúr parece de parajes muy distartes, que el moverlas y colocarlas de! modo que se ven parece impo sible a los Indios rue se hallaron al tiempo de la Concruista. Dedicóse después este templo a San Juan Rautista, clordes estí el Pueblo de Vilcas. A una legua de éste, a! fin de un pequeño Valle de mejor temple, que llaman Pamacochà, se reconocen las ruinas de los Palacios del In:Ca, ce.ia misma materia, y en sus cercanías hay también vestigo: de caserios, que a lo que se discurre servian de alojarniento a la familia y Cacique de su séquito. El temperamento de esta Provincia es templado e. su mayor parte y muy sano, aunque en las partes bajas vecinas al al Río es bien caliente. En estos parajes se dan Cañas de Azúcar, Plátanos y demás frutas $Y$ verduras que se dan en la Costa, como también Ají y Algodón. En los demás, a proporción de los ternples que gozan, se cultivan de tocios los dernás trutos y semillas, Trigo, Maíz, Papas y menestras. Hay de todol géneró decGanados másores y menores. De las lanas destos y de las que se traen de otras pattes, se fabrica mucha ropa de la tierra: Pañetes, Fayetas, Sayales etc., en algunos Obrages que hey en esta Provincia. Hay también Vicuñas. En otro tiempo se trabajajaron algunas minas de plata. Hoy no se conoce alguna. Tiene esta Provincia un Santuario en Huambalpa de una devotísima Imagen de la Concepción de Nuestra Señora, a cuya fiesta concurre mucha gente de otras Provincias. Aunque como dijimos, el temperamento de la Provincia es sano, mueren con todo muchos Indios en los parajes calientes, particularmente en los meses de Noviembre a Marzo, en que se padecen calenturas acesionales, que llaman Chucchu, por falta de dieta y curación. Por esto apenas sus habitantes pasan de 5,000.

Comprende esta Provincia 10 Curatcs. El I es el de Vilcas. Tiene cinco anexos que son: Huambalpa, Acomarca, Huanmarca, Cicha y Huarcay. El II es el de Vischongo. Tiene cuatro anexos que san: la Concepción, Chacamarca, Chumbes y Ocros. El III es el de Zancos. Tiene dos anexos que son: Lucanamarca y Sacsamarca. El IV es el de Canaria, 
con un anezo nombrado P̈pongo. El V es el de Hualla. Tiene cuatro anexos que son: Tiquihua, Cayara, Mayobamba y Cachi. El VI es el de Fuancapi, que en oiro tiempo se llamó de Colca. Tiene tres anexos que son: Colca, Quilla y Pitahua. El VIİ es el de Huancarailla. Tiene siete Pueblos, pero casi despoblados. El VIII es el de Chuschi. Tiene cinco anexos que scn: Sarhua, Auquilla, Tomanga, Canchacancha y Huaroaya. El iY es el de Totos. Tiene cuatro anexos que son: Paras, Espiti, Vilicancho y Cocas. Fi $X$ es ei de Cancjallo, Capital de la Provincia por residir en este Pueblo el Corragidor. Tiene tres anexos que son: Putica, Huancarucma y Pomabamba. Por el Noroeste parte al Este sigue a la:

FROVINCIA DE ANDAHLAYL.RS

Confina por el Nordeste con la de Abancay; por el Este con la de Aymarcies; por el Sudoeste con la de Parinacochas; por el Sur con la do Lucanas; por el Oeste con la de Vilcashuaman; y por el Noroeste con la Ceja de la Montaña de los Andes, por donde no hay memoria que hayan hecho irrupción en esta Provinciá los Indios infieles que habitan en lo interior de aquellos montes. Son sus bosques muy cerrados. Tiene de largo del Noroeste al Sur 24 leguas y 15 de ancho. Pasa por alla el camino real de Lima al Cuzco. No hay más Río considerable que el que baja por la Provincia de Vilcashuaman, el cual divide en partes a los dos. Llámase en este Río de Pampas. Corre a incorporarse con el de Angoyaco $\circ$ antiguo Marañon. Tiene um puente de triznepas de 30 varas de largo y una y media de ancho, por donde pasan las cargas que se llevan de Lima al Cuzco y del Cuzco a Lima. Hay en" esta Provincia una laguna de 10 leguas de circunferencia, y su desague es un corto raudal que abastece al Pueblo de San Jerónimo. Fructifica esta Provincia Trigo, Maiz y demás semillas, como también casi todo género de frutas; y por tener parajes fríos y de Punas, se cultivan los frutos correspondientes a este temperamento. Pero de todo esto solo hay lo que basta para el consumo de la Provincia. El renglón único del Comercio es el de Azúcar. del cual se cogen de 30 a 40,000 arrobas en varias Haciendas, entre kas cuales se hallan la de Mozobamba, vínculo de los Marqueses de este Título. Lo más particular de esta Provincia es el célebre Santuario de Cocharcas, Pueblo anexo del Curato de Chincheros. Venérase allí una Imagen de Nuestra Señora de las más prodigiosas que tiene el fleyno, pues sus innumerables milagros han excitado tanto la devoción que la ha erigido un magnífico Templo, adornado de ricas y sobresalientes alhajas, extendiéndose tanto que de lejanas tierras vienen a solicitar su 
protección y a darle gracias de los beneficios recibidos. Su principal festividad se celebra el día ocho de septiembre, a que concurre innumerable gente y se celebra una feria que dura 12 días. Los habitantes de esta Provincia llegan a 12,000.

Comprehende 10 Curatos. El I es el de Andahuaylas. El II es el de San Jerónimo, con un anexo nombrado Andarapa. El III es el de Talavera, con un anexo nombrado Cascabamba. El IV es el de Chincheros. Tiene siete anexos que son: Jripa, Casabamba, Cayera, Cocharcas Uchucbamba, Uracmarca y Maray. El $\mathrm{V}$ es el de Ongoy. Tiene dos anexos que son: Ocobamba y Piscobamba. El VI es el de Huancaray. Tiene dos anexos que son: San Juan Evangelista y Turpo. El VII es el de Cachi, con un anexo nombrado Chulisana. El VIII es el de Huayana. Tiene dos anexos que son: Chacrapampa y Cheara. El IX es el de Pampachiri. Tiene dos anezos nombrados Pomacocha y Unamarca. El $\mathrm{X}$ es el de Huncamará.

DESCRIPCION DE LAS PROVINCIAS PERTENECIENTES AL OBISPADO DE AREQUIPA (26).

El Obispado de Arequipa, fundado en 1609 comprende seis Provincias que son: la de su nombre, la de Camaná, de Condesuyos, de Collahuas, de Moquegua y la de Árica. De la primera es Capital la Ciudad de Arequipa, cuya fundación se efectuó en 1539 de orden de Don Francisco Pizarro, enleltúgar en quehoyase halla. Está en $17^{\circ}$ $25^{\prime}$ de latitud al Sur Jy en $306^{\circ}$ C $25^{\prime}$ de longitud suesto el primer Meridiano en la Isla del Ferro. Su temperamerito, aunque llueve en ella, es notablemente seco pero benigno, y sus aires muy sanos, como asimismo todo su Territorio y Jurisdicción, que es de extensión bien corta. Sus Casas son hermosas, fabricadas regularmente de piedra con cubiertas de bóveda, sin viviendas altas por recelos de Temblores. Ha sido varias veces arruinada por éstos, como en los años de 1600 y 1604 , en que se reventó el Volcán Omate, distante de la Ciudad 20 leguas, sito en la Provincia de Moquegua. También ha padecido otros estragos por Temblores en los años de 1784 que se arruinó toda.

Está situada esta ciudad a la falda de un alto Monte, que se eleva entre otros que la rodean hacia la parte de la Sierra y que, aunque cubierto todo tiempo de nieve, vomitó llamas antes de la Conquista. Ba-

(26) El Conocimiento de los Tiempos. Año 1765, 28 pp. s.f. 
ña la Ciudad un Río nombrado Chili, de cual se sacan Acequias para regar sus contornos y cultivar sus Campiñas. Tiene su origen de la Provincia de Lampa y entra en el Mar del Sur, habiendo regado antes un ameno valle nombrado Vitor. Es gobernacia pór un Corregidor que preside: al Cabildo secular, compuesto de dos Alcaldes ordinarios, Alférez reàl, Alguácil māyor, Regidores y demás oficios respectivos. La Iglesia Catedral tiene cinco dignidades: Deán, Arcediano, Chantre, Maestre-Escuela, Tesorero, dos Canongías de oposición: magistral y doctoral, una de merced y dos raciones. Se regulan al presente los habitantes a 40,000, incluso los de cinco leguas en contorno de la Ciudad, habiéndose en estos tiempos aumentando sus habitadores. Hay siete Conventos de Religiosos y tres de Monjas. Aquellos son: de Santo Domingo, de San Francisco, de San Agustín, de la Merced, de la Compañía de Jesús, de San Juan de Dios y, a la otra parte del Río, el de Recoletos Franciscanos. Hay tamibién un Hospicio de Padres de la Buenamuerre. Loss de Monjas son: de Santa Catalina de Sena, de Santa Teresa y de Santa Rosa; tiene también un Colegio Seminario, una Casa de Mujeres Recogidas y un Beaterio de Indias y dos Casas de ejercicios: una para hombres y otra para mujeres, de moderna fundación. La Provincia confina, por la parte del Norte con la de Collahuas, por el Este con la de Lampa, por el Sudeste con la de Moquegua y la de Arica, por el Oeste con el Mar del Sur, y por el Noroeste con la de Camaná. Tiene de largo Noroeste-Sudoeste 16 leguas y de ancho, por donde más, d2 Hálladse ensu Costa dos Caletas que son la de Islay y la de Chule, y un Puerto poco seguro, nombrado Arantac, en 16" 53" "Los frutos de este Corregimiento, con que-comercia con otras Provincias, se reducen a Vinos, de que se cogen en el Valle de Vitor más de 170,000 botijas al año. Los demás no son escasos, como Trigo, Maíz, Papas y Azúcar, aunque anda algo escasa la Carne. Los Ríos que la riegan son: el de Tambo, que bajando de la Provincia de Chucuito y corriendo para la Costa, riega el valle de Tambo, y el nombrado Chili, al que se incorporan algunos arroyos. Uno de ellos se forma de la agua que continuamente destila del hueco de una grande peña, la cual por fuera es sumamente árida. En la Ciudad hay muchas familias notables y algunas descendiente de los primeros Conquistadores de este Reino y de los fundadores de esta Ciudad. Para remediar en parte la grande sequedad del temperamento, es regada la Ciudad de muchas Acequias y Fuentes, entre las cuales es muy hermosa la de la Plaza, que es dz bronce, como también lo es el Puente de piedra de seis arcos, por lo sóiido, elevado y espacioso por donde se pasa el Río al Norte de la Ciudad. 
Comprende en la jurisdicción de este Corregimiento 11 Curatos. Dos en la Catedral, a los cuales pertenecen todos los Españoles de los contornos de la Ciudad. El III es el de Santa Marta de Indios en la misma Ciudad, los cuales tiene Cabildo separado con Regidores y Alcaldes, que se eligen anualmente. El IV es el de Chihuata, de temperamento frío. Llega su jurirdicción hasia una laguna, de donde se saca mucha sal, de que se provee la Provincia y se lleva a otras partes para el beneficio de los metales de plata. El V es el de Characato, en cuya Iglesia, que es hermosa, se venera particularmente una portentosa imagen de Nuestra Señora de la Purificación o Candelaria. El VI es el de Paucarpata. El VII es el de Tiabaya. El VIII es el de Yanahuara. El IX es el de Cayma. El X. es el del valle de Vitor. El XI es el del valle de Tambo. A la parte del Noroeste está situada la:

\section{PROVINCIA DE CAMANA.}

Confina esta con la Provincia de lca por el Noroeste y Norte; con la de Lucanas por el Nordeste; por el Este con las de Parinacocha y Condesuyos; por el Sudoeste con la de Collahuas; y por el Oeste con el Mar del Sur. Tiene de largo Noroeste-Sudoeste 25 leguas, y por donde más 14 de ancho Este-Oeste. Compónese de muchos Valles, de los cuales los más terminan en la Costa. Sus nombres son: Majes, Camaná, Quilca, Ocoña, Atico, Chaparra, Chala, Yauca y Acari. Al Sur, antes del de Majes, está el de Sihuas, que tiene 10 leguas de largo. Las cinco hacia el mar son de la Jurisdicción (Ridal del estanprovibeia; pero por lo que mira a la eclesiástica, pertenece todo al Curato de Sihuas de la Provincia del Collahuas. En estos Valles se coge cantidad de Ají, Vinos, Aguardientes en abundancia, especialmente en el de Majes, Aceite en copia, muchos Higos y algunas semillas, todo lo cual se comercia con las Provincias comarcanas de la Sierra. Su temperamento es como el de Lima. Hacia la parte de la Sierra llueve algo, y por esta parte se hallan muchas Minas de Oro, que por la dureza de los metales, grandes costos y escasa ley dan poca utilidad. Hállanse Minas de Alcaparrosa, y en un Cerro muy alto, nombrado Huatiapa, Minas de Cristal de varios colores. Todos estos Valles son regados por riachuelos que bajan de la Sierra, de los cuales algunos se hacen caudalosos por los meses que llueve en ella, que son Enero, Febrero y Marzo. Los demás del año escasea el agua, a excepción de algunos, que la tienen siempre abundante como el Majes y Ocoña. En estos hay abundancia de Pejerreyes, Lisas y Camarones, especialmente en el primero, en el cual se cría un animalejo 
de figura de Gato, que se alimenta de los Pejerreyes que pesca. Es Provincia pobre y mucha gente miserable se alimenta en lugar de Pan, con Higos pasados en algunos de sus Valles. En su Costa hay algunas Caletas, como son la de Atiquipa, la de Ocoña, la de Camaná y la de Quilca. Cógese en ellas bastante Pescado, que parte de él se conduce a la Sierra. Hay también algunas pequeñas Islas, donde se saca Huano que sirve para aumentar la fertilidad de la tierra.

Comprende esta Provincia siete Curatos. El I es el de Camaná, que es la Capital. Esta es una Villa a dos leguas del Mar, situada en un paraje cieleitable a la vista por la fertilidad, amenidad y colocación de sus tierras, regadas por las aguas del Río de Majes, que entra al Mar por aquella parte, formándose un hermoso soto, en que hay variedad de Pájaros. En otro tiempo fué algo considerable. Hoy su vecindario apenas llega a 1,500 almas, por haberse avecindado sus principales familias en Arequipa. Tiene un anexo, que es el Pueblo de Quilca, Puerto o por mejor decir Caleta, a que siguen otras que sirven de pesquerías en sus contornos. Hay allí cerca, Minas de Talco, de cuyo efecto hacen comercio sus habitadores. El II Curato es el de Aplao. El III es el de Huan. carqui. Estos dos están en el Valle de Majes, uno a un lado y otro ai otro del Río, sin Pueblos en forma, porque una y otra ribera se compone de Pagos o Haciendas separadas, en las cuales se cogen más de 90,000 botijas de Vino, que la mayor parte se reduce a Aguardiente. El IV es el del Pueblo de Ocoña. El Vtes el de 'arayelín hacia la Sierra, de que es anexo el Valle de Atico. El VI es el de Chala, de que son anexos el Valle de Chaparrá cónun mifieral rivmbradorehumillo, el Pueblo de Tocotay y el de Atiquipa. En la jurisdicción de este Pueblo hay unas grandes Lomas o colinas fertilísimas, que llaman de Atiquipa, en cuyos pastos se mantiene un crecido número de Ganado mayor y menor, como también mular y muchos Borricos, géneros todos de comercio. El VII Curato es el de Acarí, en cuyo valle a un lado hay elevado cerro, nombrado Sahuacarí, compuesto de piedras muy grandes y copia de arena, en el cual en ciertos tiempos; especialmente en los meses de Noviembre, Diciembre y Enero, se oye un ruido grande y contínuo, que causa admiración. En su falda hay dos viejas fortalezas del tiempo de la gentilidad. Son anexos de este Curato los Pueblos y Valles de Yauca y Jaquí. Ail Este está situada la

\section{PROVINCIA DE CONDESUYOS DE AREQUIPA}

Confina esta Provincia por el Norte con la de Parinacochas, por el Este con la de Chumbivilcas, por Sudoeste con la de Canas y Canchis, 
por el Sur con la cie Collahuas. Su temperamento es universalmenle frío, aun en aqueilos pueblos que menos altos están a la falda de la Cordillera. Es Provincia muy quebrada y de malisimos caminos. Ј̈u Capital, aun con distar solo cuatro leguas de la Provincia de Camaná, es bien desacasible. Con todo se coge Lasianie Trigo, Maiz y ciras semillas en los lugares bajos, y aun alcgunas frutas como: Uvas, Peras, Fresas y Manzanas, etc., con algunas Flores. También en algunos parajes se coge Grama, que alli llaman Mac.10. la cuál venden los Indios a cambio de Bayetas de la sierra y Coca. Donde abunda más es er: el Pueblo de Chinuas. Como no la cultivan ni benefician no es tan fina como en oiras paites; pero con todo eso se emplea en tintes de Lanas. Cercá de Orcopampa se hallan unos baños de agua caliente, que aseguran ser útiles para Gálico y Lepra. Hay algunas Minas de oro, que se trabajaron en otro tiempo, hoy, por su corta ley, y mucha profundidad y dureza no se trabajan como antes; aunque no dejan de sacarse algunos castellanos de una u otra, como son la de Arirahua, Quiquimbro, Arauro y Ainacolca, en que apenas se costea el trabajo. El oro es de 19 a 29 quilates, dando por cajón de tres a cuatro onzas. Trabújanse a fuerza de acero y pólvora, y los metales se muelen en trapiches. La ocupación de los naturales de la mayor parte de esta Provincia es de llevar los electos del Valle de Majes de la de Camaná, que son principalmente Vinos y Aguardientes, a varias Provincias de la Sierra, en el cultivo de sus sementeras y algunos en la labu: de Minas. Riegan esta Provincia algunos arroyos y riachuelcs, que $1 \mathrm{ci}$ más se incorporan a dos fíos graffdes, el unolde race en la Provincia da Chumbivilcas y sale al Mar por el Valle de Ocoña de la de Camaná, y el otro que le entra de la de Collahuas y pasando por el Valle de Majes desagua también en el Mar, a dos leguas de la Villa de Camaná.

Comprende esta Provincia nueve Curatos y un Pueblo perteneciente a otro de otra Provincia. El I es el Curato de Chuquibamba, Capital de esta Provincia. Tiene un anexo, nombrado San Pedro de Illamas. El II es el de Andaray. Tiene por anexos los Pueblos de Yanaquihua $\mathrm{y}$ el de Chorunga en su Valle y el de Alcapay, asiento de minas. El III es el de Salamanca. Tiene por anexos los Pueblos de Chichas, Quechualla, Belinga y el asiento de Arirahua. El IV es el de Andahua. Tiene por anexos el Pueblo de Chilcaymarca y el asiento de Huancarama y Orcopampa. El $V$ es el de Chachas, con un anexo nombrado Ayo. El VI es el de San Juan Crisóstomo de Choco. Tiene por anexos los Pueblos de Ucuchacas y Llanca. El VII es el de Viraco. Tiene dos anexos, nombrados Machahuay y Tipán. El VIII es el de Pampacolca. El IX es el 
de Cayarani, de nueva erección. Tiene dos anexos, que son el asiento de Arcata, donde se trabajan Minas de Plata que en otro tiempo dieron un crecido número de marcos y el Pueblo de San Roque de Umachulco, que pertenecía al Curato de Andaray. Además de estos Pueblos hay en la jurisdiccićn real de esta Provincia uno, nombrado Sayna, que es anexo del curato de Zayla de la Provincia de Parinacochas. Hacia la parte del Sur cae la

\section{PROVINCIA DE COLIAHUAS Y ASIENTO DE CAYLLOMA.}

Confina por el Nordeste con la Provincia de Chumbivilcas, por el Este con la de Canas y Canchis alias Tinta, por el Sudoeste con la de Lampa, por el Sur con la de Arequipa, y por el Oeste con la de Camaná. Tiene de largo Sudoeste-Noroeste 52 leguas y de ancho 16. Su temperamento es frío por estar situado en la Cordillera, a excepción de la parte que confina con la de Camaná que es bien templada, especialmente en las cinco leguas que entra su jurisdícción en el valle de Sihuas, cuyas otras cinco hasta el mar son de la de Camaná. Sus frutos son varios. Los de dicho valle son Vinos, Aguardientes, Trigo, Maíz, Legumbres y Frutas, principalmente Higos, de los cuales pasados se alimenta la gente pobre. Los frutos de los demás de lar Provincia son como los de las otras en igual temperamento y situación, y éstos escasos. Pero hay copia de Ganados mayor y mènori carneros de la tierta, Vicuñas y algunos animales monteses. Sus caminos son bien peligrosos, por ser su terreno sumamente desigual. Lo más de ella es una quebrada, por la que se despeña, más bien que corre, un Río de bastante agua, que toma su orígen dentro de la Provincia, a poca distancia de la de Lampa, en un paraje nombrado Patacapuquio, que quiere decir cien ojos de agua. A las cinco leguas de su origen tiene un puente natural de una sola peña de ocho varas de largo y cuatro de ancho. Aun con ser muy profundo el cauce de este Río por allí, suele rebalsar el agua por encima en tiempo de lluvias. Desde la mitad de la Provincia, cerca del Pueblo de Huambo, tuerce su curso y entra a la Provincia de Condesuyos de Arequipa, desde donde prosigue al Mar por el Valle de Majes de la de Camaná. Hay también otros riachuelos, cuyas aguas entran en este río, y otras van a juntarse al Apurímac. Entre los cuales es notable el que riega el valle de Sihuas, a donde baja por una quebrada diversa de la grande. Este nace, o por mejor decir brota como un penacho grande de la cima de un pequeño cerro que tendrá de cinco a seis estados de alto y ciento y cincuenta varas de circuito. En sus cercanías no se ven señales de hume- 
dad por estar rodeado de peñas. Parece una cascada hecha por el arte para diversión y recreo. Hay en esta Provincia muchas Minas de Plata de que en otro tiempo se sacó mucha riqueza, pues llegaban a 80 y 100 Marcos por Cajón. Han escaseado mucho por la gran profundidad en que hoy se hallan, pues hay alguna que tiene 200 estados; pero todavía se trabajan con bastante utilidad. El Cerro principal de estas Minas, que dió ocasión a la fundación del Pueblo y asiento de Caylloma, está a dos leguas de este asiento, cuya distancia es de subida. En sus contornos hay muchas vetas que se trabajan, y otras que han dado en agua. Hállanse también Minas de Oro, Estaño, Plomo, Cobre y Azufre, que no se trabajan porque no costean el trabajo. Este Mineral es uno de los más antiguos del Reino; y se cree será de larga duración, porque hay apariencias de que hay muchas vetas por descubrir. Los Metales se muelen en Trapiches con el agua de un arroyo, que nace a cuatro leguas de este asiento. $Y$ para que no falte agua, hay en las cercanías una laguna nombrada Vilafro, de una legua de circuito, de la cual en tiempo de se cas, que es por los meses de Agosto, Setiembre y Octubre, por medio de compuertas se deja salir el agua necesaria para las moliendas. En tiempo de lluvias la cierran para que se llene y sirva cuando se necesite.

Comprende esta Provincia 15 Curatos. En el Pueblo y asiento de Caylloma, que hoy es Capital de la Provincia por razón de las minas inmediatas, hay dos Curas respectivosa dos-Parroquias: una de Españoles y otra de Indios. Hay otra Iglesia, que llaman del Hospital porque

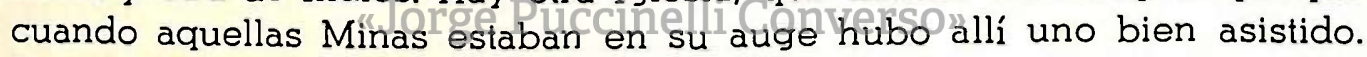
El terreno comarcado a este asiento es muy estéril, pues ni aun pastos produce para ganados por estar en medio de dos Cerros sumamente áridos y fríos. Venérase en la Iglesia de los Españoles de este Pueblo una Cruz de cristal opaco y ceniciento muy perfecia, del tamaño de un geme, que con otras dos (de las cuales es tradición que una se remitió a España y otra se quebró) fué hallado el día dos de Mayo, a los principios del descubrimiento de este Mineral, en la profundidad de 40 estados de una Mina a un tiro que dió un barretero. Estaban en forma de Calvario, siendo esta la mayor. La Caja real de este Pueblo se erigió sólo para los quintos; sin incluír otro ramo en ella. El III Curato es el de Tisco. El IV es el de Callalli. El V es el de Sÿbayo. El VI es el de Tuti. El VII es el de Chibay, con un anexo nombrado Canocota. El VIII es el de Coporaque. El IX de Lari. El X el de Madrigal, con un anexo nombrado Tapay. El XI es el de Yanqui, que era Capital de la Provincia antes del descubrimiento del Mineral de Caylloma. El XII es el de Achoma. 
Cerca de este Pueblo hay un Volcán nombrado Ambato y también Sahuancuna, que arroja humo y llamas que se ven claramente de noche. El XIII es el de Maca, con un anexo nombrado Ichupampa. El XIV es el de Chabanaconde. Tiene dos anexos, que son Pinchollo y Huambo. En este Curato se halla una laguna nombrada Mocorca, de tres leguas de circuito, en donde se cría un pescado, que comen los Indios y llaman Ispi. También hay un arroyo, del cual para el cultivo de las tierras se sacan algunas A-cequias, en las cuales cría el agua unos costrones como piedras pomas que con el tiempo se endurecen mucho. Se ven obligados los Lábradores a limpiarlas dos veces al año, porque de no se ciegan y se impide el curso del agua. Se observa que las tierras se van esterilizando y que dichas aguas bebidas son nocivas a la salud. El XV Curato es el de Llauta. Tiene cuatro anexos, que son: Huanca, Murco, Taya y Yura. Junto a este último, cosa de una legua, hay un Cerro de piedra de Cal que se beneficia allí en hornos y se conduce a la Ciudad de Arequipa, hasta donde cuentan siete leguas. El XVI Curato es el de Sihuas, con un anexo nombrado Hucán. Este Valle, que sale al mar por la Provincia de Camaná, tiene 10 leguas; las cinco últimas solo pertenecen a la jurisdicción real de dicha Provincia, pero todo el Valle pertenece a este Curato. Hacia la parte del Sur sin confinar con esta, cae la:

\section{PROVINCIA DE MOQUEGUA Ca de Letras}

Esta confina pótel Nortel connalprovincia dequampa, por el Nordeste con la de Paucarcolla o Puno, por el Este con la de Chucuito, por el Sur y Sudoeste con la de Arica, y' por el Oeste con la de Arequipa. Su temperamento es por la mayor parte frío, por estar esta Provincia situada en los altos y faldas de la Cordillera, cuyos Cerros están siempre cubiertos de Nieve. Hacia la parte baja, por donde confina con la de Arica y algo con la de Arequipa, es de buen temple y también algunos Valles que forman la vertientes de la Cordillera, en uno de los cuales está situada su Capital. Tiene muchos Volcanes en la Cordillera, que casi continuamente respiran fuego; y el año 1600 reventó uno, nombrado de Omate, que inundó casi toda la Provincia de ceniza, dejando muchas tierras que antes se sembraban inútiles para este efecto, cuyo estrago llegó hasta la de Arequipa, en donde padeció mucho su Capital y muchos Pueblos con espantosas ruinas. Hay en esta Provincia algunas Minas de Plata que se trabajan, pero de poco provecho. Sus frutos son: mucho Maíz, que se lleva a las Provincias vecinas, y vinos, que la mayor parte 
se reducen a aguardientes y llevan a las de la Sierra. De este fruto se cogen en el Valle de la Villa de Moquegua cerca de 60,000 arrobas. Produce también esta Provincia alguna Azúcar, Trigos y otras semillas. Hay bastante Ganado mayor y menor y los demás frutos y animales de Sierra. Riéganla varios arroyos que bajan de la Cordillera y de muchos de estos se forman los ríos. El uno algo caudaloso baja al Mar por el Valle de Tambo de la jurisdicción de Arequipa. Sus aguas son malas por entrarle hacia su origen algunos arroyos de agua caliente y muy fétida. El otro es menor y se forma principalmente de tres arroyos, que pasan por la Capital de la Provincia y sus inmeditaciones, y después de regar las mejores tierras de ella entra al mar por el Puerto de llo, perteneciente a la de Arica.

Comprende esta Provincia seis Curatos. El I es el de la Villa de Moquegua, que es su capital, fundada en un Valle muy ameno con el nombre de Santa Catalina de Guadalcázar, en tiempo del Virrey Marqués de Guadalcázar, hacia los años de 1626, aunque en el gobiern.: anterior del Príncipe de Esquilache estaba su población sobre los cortos fragmentos de un Pueblo del tiempo de la gentilidad. Tiene Cabildo secular con facultad de elegir Alcalde y los demás oficios consejiles que preside el Corregidor. Por lo regulai etus oficios están en personas nobles, de que no carece esta Provincia, por haberse avecindado en ella algunas familias ilustres. En cuanto a lo militar, como sucede en casi todas las Proyincias de costa y vecinas a éstas', tiene varias Compañías urbanas con sus respectivos jefes, para en caso de guerra ocurrir a la defensa "delr puerto cdènllo,i quenaunque es de la jurisdicción de la Provincia de Arica dista poco de ésta o donde fuere necesario. Todo el vecindario de esta Villa, incluso el Valle, llega a 6,000 almas de todas edades sexos y castas. Tiene tres Conventos: de Santo Domingo, de la Compañía y de religiosos Bethlemitas, y un Hospicio de Religiosos Franciscanos de la Observancia, que están procurando hacer fundación de Convento. El II Curato es' el de Torata, en donde se venera una milagrosa imagen de Nuestra Señora de la Purificación, cuya devoción no solo se extiende a toda esta Provincia sino también a las inmediatas. Este Cura da pasto espiritual a unos Indios de un Valle inmediato, nombrado Tumilaca, que pertenece al Curato de Carumas. El III Curato es el de Carumas. El IV es el de Puquina. Tiene tres anexos que son: Coalaque, Omate y Quinistacas. $\mathrm{El} \mathrm{V}$ es el de Ubinas, Pueblo situado al otro lado de la Cordillera hacia el Este de esta Provincia. Su situación es a la falda de un gran Volcán, que respira continuamente fuego, del cual se observa que por 
el mes de Cctubre suele algunos años arrojar crecidos golpes de agua turbia y hedionda, por la misma boca por donde se reconoce el fuego. Pertenece a este Curato una Iglesia de bastante adorno y no de vulgar fábrica, que está en un paraje nombrado Ichuña, que es un Trapiche de moler metales de Plata de un Mineral inmediato, el cual, aunque hoy da pcca, pero las circunstancias del Templo manifiestan haber sido bastantemente rico. El VI Curato es el de Pocsi, hacia la parte de Arequipa. Tiene dos anexos que son: Mollebaya y Socay. Al Sudoeste de esta sigue la

\section{PROVINCIA DE ARICA.}

Confina ésta por el Norte con la de Moquegua; por el Noroeste con la juriscícción de Arequipa; por el Oeste con el Mar del Sur; por el Sur con la Provincia de Atacama; por el Sudeste con la de Lípez; y por el Este con la de Pacajes. Tiene de largo Noroeste-Sudeste 82 leguas y 16 de Este a Oeste. Esta Provincia, como casi todas las de esta Costa, se compone de Valles que empiezan en las quebradas y vertientes de la Cordillera y por la mayor parte finalizan en la playa del Mar del Sur. Los intermedios de Valle a Valle de ésta son áridos e infructíferos y solo sirven alguncs para pastos en aquellos meses que cae aquella corta llovizna que, como hemos dicho, llaman Garúa, que son desde Mayo a Setiembre. En los Valles, que por la mayor parte son fértiles, por Bnolaltarlescagud, ese cogenabastante Maíz, Trigo, frutas y semillas en abundancia. Gultíyase mucho Ají, que se comercia con las Provincias de la Sierra y no poco Aceite, Algodón y a!guna Azírcar. En este siglo pasado solía valer el Ají a esta Provincia cada año 200,C0C pesos. Hácense también abundantes cosechas' de Vino y Aguardiente. Es celebrado en orden a este efecto el del Valle de Locumba por su calidad. En los altos hacia la Cordillera se cría algun ganado mayor y menor y carneros de la tierra, con los frutos de su temperamento como son Papas y algún Trigo, especialmente en el Curato de Ilabaya, de que se abastece la inmediata Villa de Moquegua. Para fertilizar las tierras se valen también aquí los labradores del beneficio del Huano, que es el estiércol de unos pájaros nombrados Huanaes, el cual traen de una Isla inmediata a la Costa, nombrada Iquique, que está en $20^{\circ} 20^{\prime}$ de altura. Tiene esta Provincia muy pocos ríos, porque los arroyos que bajan de las vertientes son de poca agua. Solo se halla uno algo caudaloso en el Valle de lca, que es por donde confina esta Provincia con la de Atacama. Tiene su origen en lo más interior de la Cordillera al Este, hacia cuya parte se haya un Vol- 
cán en un cerro muy alto, de cuyas faldas salen algunos arroyos de agua caliente y fétida. Otro río hay algo menor que baja por el Valle de Locumba, que se compone de dos grandes arroyos que bajando por dos quebradas, en dirección casi contraria, se juntan formando una laguna muy profunda de cuatro leguas de largo y media de ancho. Al fin de ella, por la parte exterior que mira a la continuación de la quebrada, hay un grande agujero sin saberse si está en el plano o en el medio de la altura del agua de la laguna. Por él sale con ímpetu grande el agua que hace el río de Locumba, corriendo siempre casi en una misma caricidad. Lo más notable de esta Provincia son sus Minas. En los alıos del Curato de Pica hay vetas de Oro y de finísimo Cobre, que no se trabajan por lo rígido del temperamento. Por la parie de la Costa se hallan los Cerros de Chanavaya y Huantajaya, a dos leguas más o menos del Mar, y otros muy ricos de metales de Plata, de los cuales muchos no se trabajan por carecer de agua aquel terreno en muchas leguas. El de Huantajaya se cree que fué trabajado en tiempos antiguos. Cerca de estos tiempos, esto es ya avanzado el principio de este siglo, se empezó a trabajar de nuevo sin método, creyendo que no había vetas fijas sino bolsones de Plata, porque se encontraban a trechos unas piedras sueltas, que llaman de barra porque se sacan de ellas por fundición grandes cantidades de Plata. Pero posteriormente se ha visto que hay Vetas fijas:y que aquellas Papas son anuncio de veta cercana. Así se han establecido-labores, en forma deaque se ha sacado y saca mucha riqueza. JoY aeno tenen dal penalidadsde la falta de agua, pues es preciso llevar a beneficiar los metales a distancia de muchas leguas de despoblado, estas Minas enriquecieran mucho a sus dueños y fueran útiles al Reino, porque se aumentaran mucho sus labores. Tiene esta Provincia en su Costa varios Puertos. El de Loa, que es por donde confina con la de Atacama, está en $21^{\circ} 30^{\prime}$. El de Iquique, a cosa de dos leguas de Huantajaya y en donde hay pesquería de Tollo, que es el Bacalao de esta América y de Congrío, que se llevan a las Provincias de la Sierra, está $20^{\circ} 20^{\prime}$. El de Pisagua en $19^{\circ} 15^{\prime}$. El de Camaiones en $19^{\circ} 15^{\prime}$. El de Vítor en $18^{\circ} 40^{\prime}$. El de Arica en $18^{\circ} 25^{\prime}$. El de Pacocha. El de Ilo en 17\% 46'. El de Maestro Lorenzo y el de la Yerba-buena que es por donde que por donde confina con la jurisdicción de Arequipa, en $17^{\circ} 35^{\circ}$. Hay cuatro caletas que son: la de Laquiaca, la de Sama, la de Meca y la de Tancona. Estos Puertos no todos son seguros.

Comprende esta Provincia 11 Curatos. El I es el de la Ciudad de Arica, que es la Capital, situada a la orilla del Mar en $18^{\circ} 28^{\prime}$. Con 
un buen Puerto, algo a sotavento. Fué muy opulenta en tiempo que por alli se remitían a Lima los caudales de Potosí y otras Provincias. Con el orden de transportarse por tierra cichos caudales, cesó el trajín y comercio y enipszó a empobrecer. Con las ruinas que ha padecido con varios temblores, ha sido desamparada de sus principales vecinos, pasándose muchos, de lucidas y antiguas familias, al Pueblo de Tacna que dista 12 leguas, en paraje más acomodado y pingüe. Desde su erección tiene Cabildo con un Alcalde ordinario, Alférez real y demás oficios, que preside el Corregidor. Tiene Caja real, cuyos Ministros están divididos en la Ciudad y en Tacna para su mejor gobierno. Hay tres Conventos de religiosos: de San Francisco, de la Merced y de San Juan de Dios, pobres y muy maltratados. El II Curato es el de Tacna. Tiene cinco anexos que son: Pachia, Pallagua, Caplira, Toquella y Estique. El. II es el de Pica. Tiene dos anexos que son: Mati!la y Fuatacondo. El IV es el de Tarapacá. Tiene cuatro anexos que son: Huaviña, Camsana, Mamiña e Iquique. El $\mathrm{V}$ es el de Cibaya. Tiene tres anexos que son: Satoca, Mocha y Pachica. El V] es el de Camiña. Tiene tres anexos que son: Minimini, Pisagua y Sipisa. El VII es el de Copta. Tiene 16 anexos que son: Pachica, Esquin̄a, Timar, Tignabnar, Sacsama, Besien, Pachania, Socoroma, Puter, Parinacota, Choquelimpe, Huayaquiri, Sora, Poconchile, Libilca y Umagata. El VIII es e! de Tarata. Tiene cuatro anexos que son: Ticaco, Chaspaya, TarucachiByl MaureteElaIXles eleder Sema. El X es el de Ilabaya. Tiene dos anexos que son: Candarave Y Locumba. El XI es el de llo. Aunque esta Provincia pertenece a la Real Audiencia de Lima, la de la Plata tiene, por ley real, alguna jurisdicción sobre su Corregidor.

\section{DESCRIPCION}

\section{DE LAS PROVINCIAS PERTENECIENTES AL OBISPADO DEL CUZCO (27).}

El Obispado del Cuzco, fundado en 1536, comprende 14 Provincias que son: la de su nombre, la de Abancay, la de Aymarass, la de Cotabambas, la de Chilques y Masques o Paruro, la de Chumbivilcas, la de Canas y Canchis o Tinta, la de Quispicanchis, la de Calcailares con Vil-

(27) El Conocimiento de los Tiempos. Año 1768, 40 pp. s.f. 
cabamba, la de Urubamba, la de Paucartambo, la de Carabaya, la de Lampa y la de Azángaro. De la primera es Capital la insigne Ciudad del Cuzco, cabeza en otro tiempo de este peruano Imperio. Fúndola en $13^{\circ} 40^{\prime}$ el primer Inca Manco Cápac en 1403 de la Era Cri: Confina por el Este con la Provincia de Calcailares y parte de la de Ouispicanchis; por el Sur con la de Paruro; por el Oeste con la de Cotabambas y parte de la de Abancay; y por el Norte con parte de ésta, y la de Calcailares. El sitio en que está no es el más ventajoso, por no ser de suelo llano y unido. Acaso los Españoles hubieran elecjido alguno de los llanos, que hay inmediatos, pero el haber hallado algunos edificios, y el ahorro de cimientos y materiales para algunas fábricas, los determinó, entre los afanes de la conquista, a no pensar en nueva fundación. Su temperamento es algo vario e inconstante, por las frecuentes mutaciones de la atmósfera, pero regularmente frío. No obstante es medianamente sano. Después de Lima es esa la mayor Ciudad de nuestra América Meridional. El distrito de su Jurisdicción es corto, como se verá por la poca distancia de los Curatos, que están extramuros, aunque en otro tiempo se estendía a casi todas las Provincias que la rodean, hasta el año de 1565, en que el Presidente Lope García de Castro proveyó Corregidores en dichas Provincias. Tuvo Casa de moneda, que aún subsiste, pero sin ejercicio. Tiene Cabildo con dos Alcaldes, Alguacil mayor y demás oficios correspondientes, que preside un Corregidor. El Cabildo eelesiústico sel compone de cuatro Dignidades, seis Canongias y Pres Racioneso Entrestas Canongias hay dos de oficio, y por oposición: la penitenciaria y magistral. Tiene ocho Capellanes de coro. Su iglesia catedral de tres norves de suntuosa, y bellísima arquitectura, está magníficamente adornada con costosas alhajas de los ricos metales del Perú y de joyas y preseas de todo género de piedras preciosas. Corrió bajo la jurisdicción de esta Iglesia y sus prelados todo el reino del Perú. Venérase en ella un milagrnso Crucifijo, dádiva del señor Carlos $V$ que llaman de los Temblores, por haberlo jurado la Ciudad en el terremoto espantoso acaecido el día 31 de marzo de 1650 . También se venera allí una imagen de Nuestra Señora de la Concepción, que llaman la Linda, dádiva asimismo del dicho señor Emperador. Tiene esta Ciudad muy buenos edificios, que pueden competir con los de Europa, calles anchas y plazas desahogadas. Goza de bastante agua conducida por cañerías de cerca de una legua de distancia, de que se abastece la Ciudad, distribuída en varias fuentes, aunque no muy saludable. La menos mala es la que se toma del Hospital. Tiene un gran arroyo que atraviesa la Ciudad, llama- 
do de Huaianay, que se forma de las vertientes de la Ciudad y su Valle y otros menores aue se juntan con él. De sus antiguos monumentos el más notable es la fortaleza, que aunque deteriorada y maltratada por là inciuria de sus habitantes e injuria de los tiempos, deja con todo ver la grandeza de los incas sus dueños, y de su construcción han querido alyunos formar un problema de no difícil solución, porque siendo algunas de sus piedras de un monstruoso tamaño, que no bastan $i, 000$ hombres para moverlas, con las caras con que se juntan unas zon otras de superficies muy irregulares y de ningún modo trabajadas a escuadra, se unen con todo sin intervención de mezcla alguna por cuanto ajuste cabe, correspondiendo unas con otras en la misma desigual e irregular superficie. ¿Con qué máquinas, dicen, se subieron á aquel cerro? ¿Con qué instrumentos la labraron los indios, que no conacieron el hierro, ni el acero? y más siendo dichas piedras durísimas. Los indios que se encontraron en la Conquista eran muy rudos para el efecto. Estas dificultades hän hecho decir que o les ayudó el demonio, o que otra Nación gigantesca anterior de que se han hallado vestigios en huesos en varias partes del Reino, fué su constructora o que los Indios sabían el arte de hacer o de fundir las piedras. Pero la verdad es que para esto no se necesitó ingenio sino gente, ni más instrumentos que otras piedras más duras para labrar aquellas. El Cuzco es de mucho comercio y bien abundante de víveres regalados, de que la abstecen las Provincias comarcanas. Tiene cerca de 26,000 habitantes de todas Castas, en que es duplicado el número de Indios al de Españoles. Entre estos hay algunas familias de conocida y antigua nobleza. Los indios excedían en número a los de hoy antes de 1720, por cuyo tiempo una cruel peste hizo un formidable estrago en ellos. Ha padecido esta Ciudad como también todas las Provincias de la Sierra, muchos y fuertes Temblores, especialmente el año de 1650, a 31 de Marzo, en que se arruinó esta Ciudad sin que quedase edificio que no padeciese estrago. Hay en esta Ciudad nueve Conventos de Religiosos que son: Santo Domingo, fundado donde era el Templo del Sol, dos de San Francisco: Observantes y Recoletos, San Agustín, la Merced, dos que fueron de la Compañía que son: el Colegio principal, que a la parte del Oriente y a espaldas de aquel estaba el Noviciado. Este Colegio era de estudios con Universidad, donde se conferían grados mayores antes de su extinsión, que fué el año pasado de 1767, a los 196 años de su fundación en esta Ciudad; San Juan de Dios con Hospital, nombrado San Bartolomé; de Bethlemitas con Hospital, nombrado la Almudena; tres Colegios; el Seminario con el título de San An- 
tonio de Abad, el cual tiene Universidad en que se enseña y confieren todos grados; el Colegio de San Francisco de Borja, destinado a la enseñanza de híjos de Caciques, y de San Bernardo de gente noble. Hay también tres Monasterios de Monjas que son: el de Santa Catalina de Sena, fundado en el mismo sitio donde estaban las Vírgenes dedicadas al Sol en tiempo de los Incas, el de Carmelitas, el de Santa Clara, suieto a la Religión de San Francisco, y un Beaterio de Nazarenas, que están solicitando licencia de clausura. Hay un Hospital de Indios y otro de mugeres blancas. Son iodos estos Conventos por la mayor parte grandes y sus Iglesias muy adornadas y alhajadas, especialmente lo era la de la Compañía, en que se empleaban en el culto 6.000 marcos de plata labrada; la de la Mer ミd y San Francisco, en que se emplean 5,000 marcos en cada una. Las fiestas se celebran con la mayor solemnidad y magnificencia, siendo la procesión del Corpus en el Curco una de las más vistosas y célebres de toda la cristiandad por eil carro rico de plata, altares en las calles, arcos y las célebres y alegres darzas, en que los danzantes van vestidos de plata de martillo, y así los demás, siendo las Imágenes de los Santos, Patronos de las Parroquias, que salen en la procesión, en suntuosísimas andas de admirables y devotísimas hechuras.

Comprende ocho Curafos. El I es el de la Catedral, servido de tres Curas: dos para Españoles y otro para Indios y Esclavos, en Capilla o Iglesia de ir ș Oncvesaquedencminasel Sagrario. El II es el de Belén. El III es el de Sam Gristóbal El IV es el de Santa Ana. El V el de San Blas. El VI el de San Sebastian, siáado a dos cortas leguas de la Ciudad. El VI se llama del F'ospita', por haberse erigido en la Iglesia de ur Hospital de Indios, que ccare al cuidado re una Hermandad de Caballeros que se dedican a asistir a los enfermos. El VII es el de Santiago. El VIII es el San Jerónimo a tres leguas de la Ciudad.

Todavía hay vestigios de los caminos isubterráneos que de las casas o palacios de los incas salían para la fortaleza, labrados con unos como dientes enclavidos como rueda de reloj, pero que permitían el tránsito de un hombre de medio lado entre uno y otro diente hasta cierta distancia y luego podían caminar dos juntos, saliendo por peñasco labrado a mano con el mismo dificultoso artificio con que se entra; ceso repentino. pues sólo un hombre podía defenderse, en cualquier in'vasión, con la misma confianza que un ejército. A la parte del Oesta está situada la 


\section{PROVINCIA DE ABANCAY.}

Confina por el Fisie cor: la gran Ciudad del Cuzco, empezando su jurisdicción desde la Parroquia de Santa Ana de aquella Ciudad, por el Oeste con la Provincia de Andalıuaylas; por el Norte con la de la Calcailares, forriando por esta parte uina larga cadena de montañas nevadas; por el Sur con la de Cotabambas y Aymaraes por el Sudceste con la de Chilọues y Masques. Su extensión Este-Oeste es de 26 le. guas y 14 de ancho. El río de más consideración que la baña es el Apurímac, que se aparta de e!la al Noroeste penetrando, unido a otros. las montañas de los Andes hasta desaguar en el Marañón, se pasa por un Puente de sogas de 83 varas de largo y 3 de ancho, y es camino real de Lima al Cuzco y a ctras Provincias de la Sierra. Págase el pasaje a cuatro reales la carga de efectos de la tierra y 12 de los de Castilla. Cría algunos Bagres. A este Río se junta otro en esta Provincia, que llarran de Pachachaca, que nace de una laguna de la cordillera de Huando y en 30 leguas de curso se hace algo caudaloso. Pásase por un Puente de piedra de buena arquitectura. Es de un arco de 16 varas de diámetro. Fabricóse en 1654. Su temperamento es templado en casi toda ella y muy sano, a excepción de uno u otro valle, en que por io excesivo del calor $\mathrm{y}$ humedad se padecen tercianas. Produce su suelo Trigo, Maíz y demás semillas en abundancia y se cría no poco ganado vacủno. Peroel principal fruto es el Azúcar, la cual es muy blanca; alguna, sino excede, iguala a la que se refina en Europa. Esta se lleva a "vender al Cuzco y otras parles." También se labra alguna ropa de la tierra. El Valle de Jaquijahuana. célebre por las batallas que en el tuvieron los Indios con los Españoles, es fecundísimo de granos, frutas y hortalizas', y merece muy bien el nombre que le dan de granero del Cuzco. No deja de haber en aquellas serranías minas de plata, especialmente en el Cerro que llaman Sallcanta, pero no se trabajan por la poca afición que tienen estos habitantes al ejercicio de Minas. Al Nordeste del Pueblo de Cachora, anexo de Curahuasi, se tenia tradición que había un pueblo de la antigüedad con el nombre de Choquequirau. Llevados algunos de la curiosidad de verlo pocos años hace, pasaron al Río Apurímac en balsas, penetraron la montaña donde encontraron un lugar despoblado, fabricado de piedra de cantería, labrado en un sitio pantanoso, cubierto de bosques y muy caliente. Se reconocieron Casas y Palacios suntuosos. Y e.s uno de ellos alrededor ciel primer patio hallaron muchos instrumentos de moler metales. La incomodidad del lugar y el tiempo no dio 
lugar a mayor investigacion. En Chinchaypucquio se ven unas piedras tan grandes y bien figuradas, que a alguna distancia parecen Casas. Créeese haber rodado de los vecinos Cerros. Por el valle de Jaquihuana pasa el camino reál de Lima al Cuzco, por una calzada de piedra de cuatro varas de ancho y tres leguas de largo, obra de los Incas para hacerlo transitable. Los habitantes de esta Provincia son cerca de 12,000 .

Comprende nueve curatos. El I es el de Abancay, Capital de la Provincia. El il es el de Huanipaca. El IIl es el de Curahuasi Tie$n$ e dos anezos que scn: Cachora y Anilla. El IV es el Limatamibo con un anexo nombrado Mollepata. El $V$ es el de Pantipata. Tiene tres cmexos que son; Pibil. Chota e Ibin. El VI es el de Chinchry. pucquio, con un anexo nombrado Sumara. El VII es el de Surite. El VIII es el de Huaracondo. El IX es el de Anta, con un anexo nombrado Pocquiura. Al Sudeste de esta sigue la

\section{PROVINCIA DE AYMERAES.}

Confina por el Noroeste y Oeste con la de Andahuaylas del Obispado de Huamanga; por el Sur con la de Parinacochas del mismo Obis. pado; por el Sudeste con la de Chumbivilicas; y por el Este con la de Cotabambas. Tiene de largo Norte-Sur 40 leguas, y de Este-Oeste 26, entrándose por eBóestè en sa digura Ia Provincia de Cotabambas. E; una de las Provincias más frogosas del Reino llena de Sierras altas y nevadas todo el año, por lo cual su ternperamento es bien frío, a excepción de algunas quebradas en que se experimenta menos frío y en donde, en algunos pedazos cortos de läderas, se hacen algunas sementeras de granos y se cultivan algunos árboles frutales, como también se cultivan algunos cañoverales y se fabrica alguna Azúcar. Pasan po: ella tres riachulos, inútiles para riego por su profundidad, los cuales juntos forman el río de Pachachaca, que entra en la de Abancay y se junta allí con el Apurímac, el cual también atraviesa un pedazo de esta Provincia al Sudeste para entrar en la de Cotabambas. Para el paso de dichos ríos hay más de 40 puentes de sogas y palos, que necesitan renovarse casi todos los años. Hay en aquellas sierras inn'lmerables vetas de Oro y Plata, que por la pobreza y poco aliento de los habitantes no se trabajan sino una u otra, pero sin mucha saca. Hay también Minas de Azogue, que por no haber licencia no se trabajan. En otro tiempo se trabajaron con conocida utilidad algunas, que hoy están aguadas. En Hayllaripa hubo unos lavaderos de Oro muy ricos. 
Dieron mucho y todcrbia se sacan algunos tomines. En est: Provinci.i hay poco ganado ovejuno: y así no se fabrica ropa de la tierra, a excepción de una ezperie de sokrecames gruesas que llaman Chuces, teiidos de lana de colores mís o menos finos. Cógese en esta Provincia Alguna grana, que aquí llaman Macno. Fué Capital de estu Provinciu un Pueblo orande y bien Lorm:ario, nombrado Tintay, el cual existe todavía pero ciespociado cor falta de aq̣ua y por una gran peste, que acabó con casi todos los habitantes. Los de toda la Provincia llegan a is ó 16,000 .

Comprende 16 Curates. El I es el de Chaluanca, con un anexo rombrado Caraybamba. Fil Il es el de Pampamarca. Tiene dos anexos que son: Catarosi y Colca. El III es el de Mollobamba. Tiene tres anexos que son: Calcauzo, Vito y Silco. El IV es el de Sabayno, con un anexo nombrado Artilla. El $\mathrm{V}$ es el de Huaquirca, con un anexo nombrado Matará. El VI es el de Antabamba. El VII es el de Oropesa, con un anexo nombrado Totora, El VIII es el de Pachaconas. Tiene dos anexos que son: Ayahuaya y Huancaray. EI IX es el de Pocoanca. Tiene dos anexos que son: Pichihua y Amoca. El X es el de Yanaca, con un anexo nombrado Sarayca. El XI es el de Ancobamba con 5 anexos, nombrados: Pampayacta, Chapimarca, Subcunga, Tiaparo y Tapayrihua. El XII es el de Syrca. Tiene cuatro anexos que son: Huayrahuacho, Chacoche, Chaluanin y Pichirhua. El XIII es el de Lambrana, con 2 anexes que son Afancama y Caypi. EI XIV es el de Colcabamba. Tiene tresolafrexos̄l quiel soñ:Clucrenchacna y Caracara. El $X V$ es el de Soraya. Tiene tres anexos que son: Toraya, Capaya y Sañayca. El XVI es el de Chuquinga. Tiene 3 anexos que son: Payraca, Mutca y Huayllaripa. Además de estos Pueblos hay uno llamado Colpa, perteneciente al Curato de Pituhuanca de la Provincia Cotabambas, y otro nombrado Lucuchanga, que pertenece al Curato de Huancarama de la de Andahuaylas del Obispado de Huamanga. Sigue la

\section{PROVINCIA DE COTABAMBAS.}

Confina por el Norte con la de Abancay y con la Chilques y Masques o Paruro, por el Sudeste y Sur hasta el Sudoeste con la de Chumbivilcas; por el Oeste y Noroeste con la de Aymaraes. Tiene de Este-Oeste 25 leguas y de Norte-Sur 23. Su temperamento es generalmente frío como las Otras de Sierra, pues casi toda ella está llena de montes, cuyas cumbres casi todo el año están cubiertas de nieve. En las partes baias hay bastantes pastos donde se cría ganado vacuno, 
y se mantienen aiguriros Caballos y Mulas, como también algún ganado menor, aunque poco. Produce esta Provincia Trigo, algún Maíz, Legumbres y Papas $Y$ en las quebradas, por donde corre el río Apurímac que de aquí pasa a la vecina de Abancay, se cogen Plátanos y frutos de Costa como Higos, Sandías y otras. Hay también bastantes Magueyes, planias cuyas hojas o pencas son de la misma figura, aun. que más grande, de la Sabila. De estas hojas se hace una especie de Cáñamo, de que se hacen soças que llaman Cabulla, de que constan las gruesas maromas con que se hacen los Puentes, que hay en los ríos de esta Provincia, lo ciue también se ejecuta en otras. En una Estancia de ganado del distrito del Pueblo de Cullurqui hay una pobre Capilla de Santa Rosa, cerca de la cual hay dos piedras bien grandes, que heridas con pequeñas piedras suenan como las campanas de mejor metal y temple. Los Indios del Curato de Mamara fabrican baque tas, suelas y zapatos, de que hacen su comercio. Hay un manantial hacia el Pueblo Aquira, en cuyas aguas se cogen pequeños y sabrosos Băgres, en tanta copia que abastecen abundantemente toda la Provincia en cuaresma y días de abstinencia. Aunque hay memoria de haberse trabajado algunas Minas de plata y oro en esta Provincia por ahora no se trabaja alguna, siendo así que sus Cerros dan muestras no solo de uno y otro metal, pero también de cobres. En un corto espacio del río de Ocsabamba, hacia donde corre ei agua con gran rapidez, se hallan ojuelitas is de plata como afrechorque arrastran el agua de la peñolería de los inmediatos montes Los ríos más notables dz esta Provincia son el de Oropesa y el de Chalhuahuacho, que desaguan en el de Apurímac, que costea la Provincia desde el Este hasta el Noroeste. En todos ellos hay Puentes para comunicarse la Provincia. De los de Apurímac, que son tres el que llaman Puente de Cutuctay tiene 86 varas de largo, y el que llaman de Choruc, que es el más frecuentado, 94. Todos son de maromas a excepción del de Ayrihuanca, que está en el río de Oropesa que es de cal y canto. Pbr haberse sumergido la barca del río Apurímac con 15 hombres y fardos de ropa de Castilla, y llevádose el Río el Puente en 1620, se pasaba por estos puentes de Lima al Cuzco y otras Provincias. Los habitantes de ella llegan a 10,000.

Comprende 13 Curatos. El I es el de Cotabambas, Capital en otro tiempo de esta Provincia. Tiene un anexo nombrado Totora. El II es el de Cullurqui. El III es el de Huayllati. Tiene tres anexos que son: Palpacachi, Llicchivilca y Corpahuasi. El IV es el de Pituhuanca. El $\mathrm{V}$ es el de Aurihuanca, con un anexo nombrado Curasco. El 
VI es el de Chuquibamba, con anexo nornbrado Vilcabamba. El VII es el de Mamara, con un anexo nombrado Turpay. El VIII es el de Aquira, porque hubo en este Pueblo dos Curas. Hoy esta última Iglesia con sus feligreses es anexo del Curato de Llacua. Tiene San Pedro un anexo, nombrado Cocha. En este también hay dos Iglesias de Santiago y San Miguel de Cocha, que igualmente pertenece al Curato de Llacua. El IX es el de Llacua con un anexo, nombrado Patahuasi, y los dos referidos. El X es el de Mara. El XI es el de Pitic, con un anexo nombrado Apomarca. El XII es el de Palcaro, con un anexo nombrado Totorhuaylas. El XIII es el de Tambobamba al presente Capital de la Provincia, con un anexo nombrado Chacato Al Norte de esta sigue la

\section{PROVINCIA DE CHILQUES Y MASQUES O PARURO.}

Confina por el Este con la de Quispicanchis; por el Sudeste con la de Chumbivilcas: por el Sur y Sudoeste con la de Cotabambas; por el Oeste con la de Abancay; por el Nordeste con el Cuzco. Su temperamento es varío segun la diversidad de lugares, y en las quebrade:; es más' o menos caliente y en las Sierras bien frío. Tiene de largo 13 leguas y-25 de ancho. Riéganla tres Ríos, fuera de varios arroyos. Ei que llaman comunmente de Cusibamba que pasa por el Valle de este nombre y entrando por la mitad de la Provincia desemboca por fin en el Marañón. El Guegllamanc deeVelillenseume al de arriba. El de Santo Tomás, que se une con el de Apurímac dentro de la Provincia de Cotabambas. Estos Ríos tienen siete Puentes para el comercio de la Provincia. Uno es de madera, y los otros de criznejas y maromas. Hay ocho lagunas pequeñas, en algunas de las cuales se crían pájaros. En los parajes calientes hay todo género de frutas. Cógense Trigo, Maíz, Legumbres y Papas. Críase algun Ganado, y en algunas partes se ven tropas de Venados. Se fabrica ropa de la tierra, pañetes, bayetas, jergas en algunos Obrajes y también Chorrillos, que son unos obrajes que se diferencian de aquellos en que no tienen Molinos de batanes, porque para tenerlos se necesita licencia del Rey. El Pueblo de Acca está situado a la falda de un Cerro con el continuo peligro que amenaza un crestón que parece está ya para caer sobre el Pueblo, el cual Pueblo se va hundiendo sin que se haya averiguado la causa. Aunque en uno $u$ otro Cerro se hallan señales de Minas, no se trabaja alguna hoy en esta Provincia, y solo se sabe que se hayan trabajado dos en tiempos antiguos. Entre los muchos Temblores que 
ha experimentado esta Provincia fué el mas formidable el del año de 1707, a 17 de Setiembre, en que se asolaron muchos Pueblos y sucedió aquel prodigio, de que hay testigos vivos. En el punto del terremcto una Haciencia pequslia del Pueblo de Coyabanilica, anexo du Capi, situada a la orilla del río de Velille, se pasó al otro lado del río con su huertecita, casa y habitanies, sin que lo sintiesen, que estaban todos en cama, por ser las doce de la noche, hallándose por la mañana en la juriedicción del Curato de Colcha. Dos casos como este han sucedido en esta América Meridicnal. Los habitantes de es'x Provincia llegan a 16,000 .

Comprende nueve Curatos. El I es el de Paruro, Capital de la Provincia. El II es el de Colcha, tiene dos anexos que son: Araypalna y San Lorənzo. El III es el de Parmpachuco. Tiene tres anexos que son: Ccapa, Cuchirihury y Paccpata. El IV es el de Accha Urinsaya. con dos anexos que scri Pilpinto y Huagaconga. El V es el de Accha Anansaya, cen dos anexos que son: Farco y Pocoray. En este Pue blo de Accha hay dos Curalos con los referidos nombres, con distintas jurisdicciones, Parrccos y anexcs. El VI es el de Omachr tiene cue tro anexos que son: Antapalpa, Quilia, Acca y Uilque. El VII es el de Capi, con dos anezos que son: Coyabamba y Tucuyachi. El VIII es el de Huanoquite. Tiene tres anexos que son: Huancahuanca, Coror y Corca. El IX ese el de Yaurisque, con un anexo nombrado Pacarictambo. Sigue di sudeste la de Letras

PROVINCIA DE CHUMBIVILCAS. "Jorge Puccinelli Converso"

Confina por el Norte con la de Quispicanchi algo y con la de Chilques y Masques por el Noroeste; por el Oeste con la de Cotabambas y Aymaraes; por el Sur con la de Condesuyas de Arequipa; y por el Este con la de Canas y Canchis. Su temperamento es por la mayor parte frío, aunque en algunas quebradas se goza templado, por la cual hay frutos de uno y otro: Papas, Trigo, Maíz, Cebada y algn. nas otras semillas y frutas, pero todo con no poca escasez. Esto y la faita de otros comercios, hacen a esta Provincia bien pobre. Abunda de Ganados principalmente Vacuno. Esta Provincia tiene anexo un Partido hacia la Costa, distante de la Provincia, intermediando Cerros nevados y corpulentos que llaman Condesuyos del Cuzco, que confina con la de Parinacochas, mediando el río que baja al valle de Majes de la de Camaná, en que hay cuatro Curatos. Fabrícase alguna ropa de la tierra. En el distrito de esta Provincia se hallan muchas boca- 
minas de plata y oro, cuyos desmontes y profundidades, como también los vestigios de varios Trapiches de metales, manifiestan que en el siglo pasado se disfrutaron sus labores con utilidad. Hasta ahora dura el nombre de las de Quibio del Curato de Chamaca, cuyos metales fueron de plata blanca. Solo se trabaja una de Oro en el Cer:o nombrado Condoray del Curato de Colquemarca. Hállase bastante grana, que llaman Macno, con que tiñen los tejidos de lana de muy bur: nos colores. Hay manantiales de Agua caliente. Ha habido en esta Provincia grandes terremotos. El 24 de Marzo del año 1739 arruinó y desoló el Pueblo de Toro, donde solo escapó el Cura y un Indio, derribadas y desechas todas las casas y la Iglesia. Buscando al otro día en el sitio del altar mayor, el depósito del Santísimo, se hallaron debajo del ara cuatro Idolos de Cobre de figura humana, el depósito o Pyxyde en el cementerio y la Imagen de bulto de Santa Catalina, Patrona del Pueblo fuera de él sobre una peña. Los habitantes de esta Provincia, incluso el partido de Condesuyos, llegan a 16,000.

Comprende esta Provincia 11 Curatos. El I es el de Velille, con un anexo nombrado Ayacasi. El II es el de Livitaca con tres anexos, nombrados Totora, Pataqueña y Alco. El III es el de Chamaca, con un anexo que es el asiento de Quibio. El IV es el de Colquemarca, con un anexo nombrado Yanque. El $\mathrm{V}$ es el de Capacmarco, con un anexo nombrado Cancahuana. El VI es el de Llauzco, con un anexo nombrado Quiñota. ElbVII es el de Santo Tomás. Siguen los que perte necen al partido de Condesuyos del Cuzco. El Vili es el de Alca, con un anexo ncmbrado PuycaP LElcix es el de Tomepampa. El X es el de Cotahuasi, con un anexo nombrado Quillunza. El XI es el de Toro con dos anexos que son: Caspi y Cupi. Sigue la

\section{PROVINCIA DE CANAS Y CANCHIS O TINTA.}

Confina por el Norte con la Provincia de Paucartambo; por el Este con la de Carabaya, hacia el Pueblo de Macusani; por el Sudeste con la de de Lampa, por la cordillera de Vilcanota; por el Sur con la de Caylloma; por el Sudoeste con parte de la de Condesuyos de Arequipa; por el Ceste con la de Chumbivilcas, dividiéndolas el río Apurímac; por el Noroeste con la de Quispicanchi. Tiene de largo Norte-Sur 30 leguas y 15 de ancho. Su temperamento es sumamente frío en la mayor parte, por tener casi toda ella muchos cerros nevados. Cultívase no obstante en ella Trigo, Cebada, Maíz, Papas, Ocas, Quinua, y en los parajes calientes, que son las quebradas cercanas a los Ríos, algu- 
na fruta, aunque no en abundancia. En los alics se cría Garado por la abundancia de pastos y también crecido núrnero de Vicuñas, Huanacos, Vizcachas, que son como Liebres o Ccnejos, Ciervos y Perdices. En los Ríos se cogen Bagres de hasta una tercia de lcirgo. Les rícs que la bañan son el de Vilcamayo, que sale de la de Quispicanchi, en el cual entra otro, que viene de las serranías nevadas de la parte del Este, nombrado Combapata, que tiene un puente de criznejas, por donde va el camino real para Potosí. Tiene so varas. El da Coporaque, que tiene in Puente de piedra. Baja de los altos de Caylloma. Hay muchas lagunas, en que se crían abundancia de aves acuáticas, como Patos. Gallaretas y otras, especialmente en la de Langui, que tiene tres leguas de largo, y una y media de ancho. Hállase piedra Imán. Fabrícase alguna ropa de la tierra. En el distrito de San Pedro de Cacha, en un paraje nombrado Racche, se ve un edificio antiguo y grande, con nueve puertas, la mitad de sus paredes de pledra labrada y la otra de tierra, sobre cinco andenes de piedra que sirven como de otros tantos muros. Dícese que sirvió en tiempo de la gentili. dad de templo de Viracocha. A una cuadra de distancia hay una laguna hecha a mano con conductos de agua que la mantienen siempre er su ser. Su sitio es una Montaña de piedra negra, que tendrá dos leguas de circuito, $y$ en sus vecindades hay vestigios de una población grande, en donde hay un mineral de tierra de que se fabrican tinajas, cántaros y otras vasijas, que se llevan a vender a las Provincias vecinas. El año de 1582, a 22 de Enero, en Yanaoca se hundió todo un Pueblo con sus habitantes.cchállanise cenvestao Provincia muchas minas de plata, pero no se trabajan al presente por haberse aguado unas y derrumbado otras, a excepción de las del asiento de Condoroma que han padecido el primer accidente. Todavía se sacan muchos marcos al año, por haber sido abundantes de plata en otro tiempo sus Minas Se han hecho muchas diligencias y costos grandes para desaguarlas, pero no se ha conseguido el intento. Todavía hay cuatro Ingenios - Trapiches corrientes. En la jurisdicción del Pueblo de Yauri hay dos Minas de Cobre, que se trabajan. También hay algunas de Orn. pero no de consideración. Se experimenta con el asiento de Condorama, y creo que será lo mismo en los demás de la Cordillera y serronías, que en las tempestades de truenos y relámpagos se sienter. en cara, manos y otras partes, unas picadas que llaman Moscas, sin verse alguno de estos animales, las que parecen deben atribuírse a efectos del aire, que está entonces muy electrizado, porque igualmente se observan en los pomos de los' bastones, en los galones, franjas y 
hebillas. En cesando la tempestad, cesan del todo. Es cosa admirable; pero es prueba de que la electricidad se hace muy activa en semejantes parajes en las circunstancias de tempestad, lo que no se ha experimentado de este modo en otras partes. Los habitantes de esta llegan a 18,000.

Comprende esta Provincia 11 Curatos. El I es el de Sicuaní, con una anexo nombrado Maranganí. El II es el de San Pedro de Cacha, con un anexo nombrado San Pablo. El III es el de Tinta, Capital de la Provincia, con un anexo nombrado Combapata. El IV es el de Checacupe, con un anexo nombrado Pitumarca. El V es el de Pampamarca. Tiene cuatro anexos, que son: Tungasuca, Surimana, Pueblo Nuevo y el de Santuario del Señor de Tungasuca. El VI el de Yanaoca. El VII es el de Langui, con un anexo nombrado Layo. El VIII es el de Checa, con un anexo nombrado Quehue. El IX es el de Pichihua, con un anexo nombrado el asiento de Condoroma. El X es el de Coporaque. El XI es ej de Yauri, con dos Capillas distantes del Pueblo: la una llaman el Santuario de la Virgen de Huancani y la otra de la Candelaria, en un trapiche de moler metales. Sigue la

\section{PROVINCIA DE QUISPICANCHIS.}

Confina por el Norte con la Provincia de Calcailares; por el Nordeste con la de Baucartambo; por el Este con la Cordillera de Vilcanota y Provincia de Carabaya; ap Sudoeste con la de Canas y Canchis; y por el Sur tocaJalgofaPla delChumbivileas; Sy nla de Chilques y Masques, con la cual confina también por el Oeste. Tiene de largo NorteSur 35 leguas y de ancho más de 30 . Su temperamento es vario. El del Valle de Oropesa, que es lo más inmediato al Cuzco, es templado y apetecible. Por esta razón tienen en ella muchos vecinos distinguidos del Cuzco, y las Religiones diversas Haciendas de Maíz, Trigo y otras semillas, frutas y hortalizas, con hermosas Casas de recreo, jar. dines y huertas, que adornan y fertilizan a un tiempo este Valle. Casi lo restante de la Provincia es frío, aunque en muchas partes se coge Trigo, Maíz y otras semillas; y en los altos hay varias Estancias de Ganados mayores y menores de que se abastecen el Cuzco, especialmente hacia el Este de la Provincia, por donde corre la Cordillera de Vilcanota, término de la jurisdicción de las dos Audiencias de Lima y la Plata hacia cuya parte, pasada dicha Cordillera, se encuentra la Montaña o Andes de Cuchoa, por donde corre un caudaloso río, nombrado Araza, que engrosándose después penetra en la Montaña de 
los Indios Infieles y juntándose con otros desagua a más de 150 leguas on el Marañón. En un Cerro nombrado Camanti, inmediato a este río hay un Mineral de Oro, y en aquellas comarcas varias Haciendas de Ccca, donde se cogen Plátanos, Piñas, Parayas, Limores, Granad!llis y otras frutas de Montaña, y se crían también varias sabandijas ponzañosas. Para seguridad contra las irrupciones de los Indios bárbaros. mantienen los inieresados del mineral alguna gente armada continua mente. Lábranse en esta Provincia no poca ropa do la tierra, ccmo pañetes, bxyetas y jergas. Hoy baños de agua caliente, de quo usaban les Incas, y algunas Minas de plata y oro, que auncrue abundaniemente en oiro tiempo, hoy por pobres no se trabajaba. Riegan esta Provincia dos ríos notables, con algún Pescado y muchos arroyos, enire ellos el Huatanay que pasa por el Cuzco y aquí va muy crecido. Descaua en el río Vilcamayo, que sale por el Norte de la Provincia a la de Calcailares y entra en la de Canas y Canchis. El otro río notable nombrado Apurimac, pasa por un canto de Provincia de Sudoeste. Otro río se forma de des lagunas que hay en Vilcanota y entra en la Provincia de Pcucartambo. A madia legua del Pueblo de Oropesa, primero al Norte de esia Provincia hay una laguna que hoy llaman la Mohina de más de media legua de largo y un cuarto de ancho, que cría mucha Totora o enea, cría algun Pescado y Aves de agua. Una punta de ella está al pie de un Cerro, nombrado Rumicolca, en cuyo sitio se ven las ruinas del Pala cio de Huáscar Inca. Hay tradición que en el centro de este Cerró están ocultos los inmensos tesorosedelos oncel Emperadores, hasta el dicho Huáscar. En solicitude de ellos han trabajado inútilmente varias personas, gastando grandes caudales, pero con los socabones solo han hallado en lo interior del Cerro algunas cuevas y bocas que llaman Chinganas y reconocido varias cañerías para conducir agua. Desde el año de 1715 hasta el de 18 repitieron muchos temblores en Quiquijana y Urcos, y aun siguieron aunque no tan frecuentes hasta el de 23. Junto al Pueblo de Urcos se halla la laguna, donde se dice haber arrojado los Indios aquella. gran cadena de oro, fabricada en el nacimiento de Huáscar. Ninguna diligencia ha sido bastante para encontrarla. Se presume que esta laguna es formada artificialmente por conductos de entrada y salida, porque siempre está en un ser, y esto desde la Conquista, siendo no grande, pues cuando más tiene 500 varas de largo y 300 de ancho; su profundidad en el centro es de 56 varas. Hay algunas otras Lagunas pequeñas y una grande nombrada Pomacanchi, de tres leguas de largo y más de una de ancho. En el Curato de Quiquijana hay unos manantiales de agua blanca, de donde toman el 
nombre de Parupucquio. Esta agua se petrifica, de suerte que las acequias por donde corie es preciso abririas por tiempos con piccs para que tengan cauce; las pajas y palos estando algún tiempo en esta agua se cubren de una costra de piedras, y no obstante se experimenta que no hace daño alguno a los Indios que son los que continuamente la beben. Hállanse salinas hacia el Sur de esta Provincia, que se comercia en ella y otras cercanas. Hay un Cerro de piedra Imán. Los ríos de esta Provincia por donde pasa el camino real para Potosí, Chuquisaca y demás Provincias de arriba, se pasen por Puentes de criznejas. La cabeza de esta Provincia es el Pueblo de Urcos, y los habitantes de toda ella llegan al número de 7,200. Antes de la peste de 1720 la habitaban cerca de 30,000 , cuya rebaja debe entenderse respectivamente de las de más Provincias de la Sierra.

Comprende esta Provincia 10 Curatos. Yendo del Cuzco el I es el de Oropesa, en cuyo Pueblo además de la Iglesia parroquial hay dos Iglesias bien adornadas; ccmo lo estún casi todas las de esta Provincia, con el títuio de Nuestra Señora de la Estrella y la Virgen de la Hermita. El II es el de Andahuaylillas. El III es el de Urcos, con anex? nombrado Huároc. El IV es el de Quiquijana. A una cuadra de este Pueblo hay una Capilla de Nuestra Señora de la Concepción o de la Virgen del Cabildo. Hállase esta Imagen pintada en una pared, que ocultaba otra unida y lä desculbrió un rayō. Está asistida en 12 Indias beatas, vestidas de sayal, que se mantienen de limosna. El V es el de Quishuares, nombrado asi por la abundancia de unos arbolitos que llaman Quishuarquishuar. Se compone de tres Pueblos que son: Punaquehuar, en este hay un Santuario bien adornado de Nuestra Señora de la Purificación, Cuyotambo y Rondocan. El VI es el de Papres. Tiene tres anexos que son: Pirque, Corma y Zanca. El VII es' el de Acomayo. Tlene dos anexos que son : Acos y Huayqui. El VIII es el de Sangarara. Tiene tres anexos que son: Marcaconga, Yanapampa y Acopia. El IX es el de Pomacanchi. Tiene tres anexos que son: Santa Lucía, San Juan y Sayhua. El X es el de Marcapata, sito al otro lado de la Cordillera de Vilcanota, a la entrada de la Montaña. Pertenecen a su jurisdicción todas las Haciendas de Cocales y el mineral de Camantt. Además de estos Pueblos, hay uno que llaman Pueblo Nuevo en esta Provincia, cuya jurisdicción espiritual toca al Curato de Pampamarca de la de Canas y Canchis, y otro nombrado Ocongate, anexo del Curato de Cacta de la de Paucartambo. Sigue la 


\section{PROVINCIA DE CALCA Y LARES.}

Confina por el Sur con la de Quispicanchis; por el Este con la de Paucartambo; por el Sudoeste con la jurisdicción del Cuzco a cuatro leguas y con la de A.bancay, formando su lindero una larga cadena de CErros nevados; y por el Nordeste y Norte con los Andez o Montaña de los Indios Infieles. Todo esta Provincia es una quebrada que tiene de largo Norte-Sur 36 leguas, y de dos a cinco de ancho. Su temperamento es templado, menos en las alturas de una y otro lado, donde hace mucho frío. Por esto goza de frutos correspondientes a uno y otro temperarnento, Trigo, Maiz, y demás semillas, con abundancia y variedad de frutas, Papas, Ocas y muchas flores olorosas. Hay bastante ganado de una y otra especie. A la parte del Este se atraviesa la Cordillera para dos espaciosos Valles, ncmbracics Quiliabamba y Amabaybamba de temperamento caliente y húmedo, muy fértil, en que hay muchos cañaverales de Azúcar. Al Nordeste se pasa también la Cordillera para los Valles de Ocambamba y Lares, que da la mitad del nombre a esta Provincia, donde tienen frutas de Montaña y bastantes maderas y muchos animales y sabandijas. Liega a ser tal su fertilidad, que las cañas de Azúcar se perpetúan por muchos años una vez plantadas, madurándose a los 14 meses, lo que es admirable, especialmente en los dos primeros. Hállanse vetas de minerales por sus Cerros; pero no se trabaja mina lalgunat, aungue en otroltiempo se sacó mucha plata de algunas que se trabajaron $\mathrm{Y}$ que están ya abandonadas por pobres de ley o por aguadas. Hay Minas de Salitre, que se lleva al Cuzco para pólvora. En el Valle de Lares hay manantiales de agua caliente. Hállanse algunas lagunas aunque no grandes. De una se sirven los labradores para regar por sus tiempos, por medio de compuertas, para que salga el agua con medida. El Río principal de esta Provincia es el de Vilcamayo, que corre por medio de la quebrada o valle, para cuyo tránsito hay varios puentes de criznejas, entra después de la montaña por la frontera de Paucartambo a juntarse con el de aquella Pro vincia. Pasa por la de Quispicanchi antes de entrar $e_{n}$ ésta. En el alto del pueblo de Lamay se ven algunos vestigios de un Palacio en forma de fortaleza, del tiempo de la gentilidad. El Cementerio de la Iglesia do Chincheros se compone de unas gruesas paredes de piedras labradas con muy buenos ajustes, con unos Nichos en forma de Garitas, que manifiestan haber sido una fortaleza, en tiempos antiguos. Sobre un Cerro inmediato sobre el Púeblo de Tambo se conserva una fortaleza fabricada de grandes peñas labradas y unidas con tan admirables ajustes, 
que no es fácil comprender como se condujeron y ajustaron no siendo de figuras regulares ni labradas a escuadra. Tiene sus baluartes, puertas plazuelas, con admirable disposición y arte. Forman su subida unos Andenes 0 escalones anchos y largos, con ciertos callejones y terraplenes. A poca distancia hay en dos partes dos castillejas, que parece servían de fcrificaciones avanzadas para defender la entrada a la dicha fortaleza. Hay en dicha fortaleza unas peñas agujeredas por donde, dicen, pasaban los Indios una cadena con que juzgaban atar al Sol, de donde tomó aquel sitio el nombre de Intihuatana, lugar donde se ata al Sol. Hay también una piedra agujereada, en que se castigaban los delincuentes haciendo pasar la cabeza por el agujero y haciendo resbalar por encima de ésta otra de filo cortante, con que se dividía la cabeza del cuerpo. En la estrechura que hacen los Cerros, se ve de piedra una estatua de un Indio vestido con una honda en la mano. En una Hacienda nombrada Huanca, del Convento de la Merced del Cuzco, se venera una devotísima imágen del Señor de la Columna, pintado en un peñasco, con mucho concurso de devotos. A la parte del Oeste, distante del centro de la Provincia, a un lado de los valles de Amaybamba y Quillabamba, está el Curato de Vilcabamba, donde ha quedado solo la memoria del retiro del último Inca en el pueblo de San Francisco de la Victoria, Ciudad populosa en otro tiempo y en que hubo ricas Minas de que sa sacó mucho caudal. Todavía se ven los vestigios del Palacio del Inca, donde los Ińlios dieron muerté crúlísima al venerable padre fray Diego Ortiz, sacerdote agustiniano en 1568. Este Curato confina con el Obispado de Huamanga. En los Valles de Amaybamba y Quillabamba, frontera de los Chunchos, no hay Pueblo formal, pero habita mucha gente en algunas Haciendas, cañaverales de Azúcar y Coca, que hay a una y otra banda del río Vilcamayo, que por aquella parte cría bastante Pescado, como Sabalos, Dorados y Pejerreyes. Para que den pasto espiritual se nombran por el Obispo del Cuzco dos Sacerdotes con título de Beneficiados o Curas de Andes, que hacen los oficios en las Capillas de las Haciendas. En estos confines, aunque a distancia, tienen sus rancherías los Chunchos de los cuales empezaron a hacer una Conversión los padres de San Francisco; pero cuando fun daba su fervor mayores esperanzas, se desvanecieron con varias irrupciones que hiciercn los gentiles, en que mataron muchos neófitos y auyentaron a otros. I'sio fué el añc 174:1 (28). Los habitantes de esta Provincia llegan a 100,000.

(28) v. Nota 21. 
Comprende esta Provincia siote Curatos. El I es el de Písac, con dos anexcs que son: Sán Salvador $y$ Täray. El Il es el de Lamay, con ur anexo nombrado Coya. El III es el de Calca, Capital de esta Provincia. E! IV es el de Lares. Tiene tres anexos que son: Hualla, Cachin y Chuquicancha. Fl $V$ es el de Chinchero. El VI es el de Ollantaytambo, que comunmente llaman Tambo, con un anexo nombrado Silque. Pertenecen a este Curato los habitantes del Valle de Ocabamba. El VII es el de vilcatarnba. Consiá de dos pueblos que son: San Francisco de la Victoria y San iuan de Lucma. Dentro de los términos de esta Provincia está colocada otra pequeña, nombrada

\section{PROVINCIA DE URUBAMBA.}

Tiene de largo tres y media leguas y dos de ancho; dista siete leguas del Cuzco. Est3, que se llamaßa el Valle de Yucay, es el Marquesado de Oropesa, que se le adjudicó, entre otras cosas, para la subsis. tencia de su casa y familia a Sayri Túpac Inca, cuando Don Andrés Hurtado de Mendoza Marquós de Câriete, Virrey del Perú, lo convidó a que saliese del incómodo retiro en que estaba en Vilcabamba y después ha vuelto a unirse a la Corona. Hay en su distrito varias Haciendas, en que se cogen Trigo, Maíz y otros granos. Hay unas Salinas, cuya Sal se Jlieva la Cuzco. CEs unepedazo de país alegre y ame no, abundante de frutas exquisitas Divídelo el Pío Vil camayo, que se pasa por dos Puentes de Criznejas y cria Bagres, muy regalados. Hay muchas familias de Indios de noble origen, pero muy pobres. Tiene cerca de 5,000 habitantes.

Comprende cuatro curatos: dos a un lado y dos al otro del Río. El I es el de Maras. A medio cuarto de legua de este Pueblo hay un Santuario de Nuestra Señora con el título de la Asunción en un campo raso y ventoso, en donde se apareció a un Indiecita tullida, sanánclola y quedando esculpida en una pared. El II es el de la Villa de Urubamba. El III es el de la Villa de Santiago de Yucay. En este Curato hay un Convento de Recoletos Franciscanos. El IV es el de Huayllabamba. Entre unas haciendas de este Curato hay un convento pequeño, en que asiste un Religioso de San Fraricisco con el título de Guardián, que administra Sacramentos con licencia del Cura a los habitantes del contorno. El sitio se llama Urquilies. Al Este de éstra y de la de Calca y Lares está situada la 
PROVINCIA DE PAUCARTAMBO.

Confina por el Noroeste y Oeste con la de Calca y Lares; por el Nordeste y Este con los Andes y frontera de los Indios infieles; por el Sur con lo de Quispicanchis. Tiene de largo Norte-Sur 26 leguas y de cinco a siete de ancho. Su temperamento en los altos es frío, pe ro en las partes bajas es templado a proporción. Produce esta Provincia bastante Trigo, Cebada, Maíz, Papas y semillas. También hay Arboles frutales. Ella es una quebrada o Valle largo, que termina en la Montaña de los Andes frontera de los Indios, en donde hay varias Haciendas de montaña en que se cultivan diversas frutas, Papayas, Limones, Sandías etc., y algún Algodón y también Coca en mucha abundancia. Por esta parte, posee esta Provincia buena y mucha madera de cedro y otras. Hay multitud de Monos, Papagayos, Loros y también Tigres y sabandijas venenosas. Pasa por esta Provincia un Río que viene de las lagunas de la Cordillera de Vilcanota, que aumentado de otros dos pequeños y varios arroyos se forma uno muy considerable, en que se pescan Sollos, Dorados, Sabalos y otros pescados. Este río, que tiene el nombre de la Provincia, y para el comercio varios puentes de criznejas, entra en los Andes y junto con el de Vilcamayo, el de Vilcabamba y después con el Apurímac va a aumentar las aguas de otros y llega al Marañón con el rombre de Ucayali. Hacia la frontera de los Indios infielesino hay memoria que haya habido Conversiones, pero el año pasado de 1767 un Religioso dominicano, sacerdote de la Provincia de Quito, que llegó a estas partes pidiendo limosna para hacer la Iglesia de su Convento, entró a la montaña y sacó más de 300 Indios bárbaros, que acariciados daban esperanza de establecer una copiosa Conversión, aunque no se puede fiar mucho de su rudeza, barbaridad e inconstancia. Hay en los Cerros de esta Provincia bastante señales de minerales de plata y oro, pues en algunos arroyos encuentran los Indios algunas pepitas, pero ninguno se trabaja. Hay también un Mineral de Azogue que se discurre puede ser abundante, pero tampoco se trabaja. Los habitantes de esta Provincia llegan a cerca de 8,000 .

Comprende cuatro Curatos. El I es el de Paucartambo, que ha corrido con el nombre de asiento. Tiene dos anexos que son: la Calle y Colquepata. El II es el de Catca. El II es el de Caycay, con un anexo nombrado Huásac. El IV es el de Challabamba. Tiene cuatro anexos que son: Huacanca, Cedros, Chimor y Amparáez. Sigue la 


\section{PROVINCIA DE CARABAYA.}

Confina por el Este con la Provincia de Larecaja; por el Oeste con la Quispicanchi; por el Noroeste y Norte con las tierras de los Indios infieles nombrados Carangues y Sumachuanes y otros, a quienes separa el famoso río de Ynampari; por el Sudoeste con la de Canas y Canchis; por el Sur con la de Lampa y Azángaro y algo con la de Puno o Paucarcolla. Por cierto tanteo que se ha hecho, como en otras muchas, tiene de Norte a Sur 40 leguas y 50, por donde más, de Este a Oeste. Sus últimos términos solo distan del Cuzco 14 leguas, aunque para ir a mula se necesita caminar por rodeo 60 leguas. Su temperamento es vario según lo más o menos elevado del terreno; en unas partes muy frío y en otras templado, es más común el primero. Críase en esta Provincia algún ganado, pcrque no faltan pastos; también se cultivan en las vecindades de los Andes y de la Montaña muchos Cocales, que en algunas partes dan tres y cuatro cosechas al año. Esta Provincia comprende hoy otra, nombrada de San Gabán, que se juntaron en una, agregando algunos de sus Pueblos a las de Larecaja, Lampa y Azángaro. Ha sido la más opulenta de oro de toda la América. Hastá el presente pasan de 33 millones de pesos lo que ha dado en oro, fuera de lo ocultamente se ha extraído. Hoy apenas se sacan al año 200 libras, por ser más costosa su saca y haber descaecido los ánimos. Se han sacado considerables pepitas de oro, entre las cuales todavía dura la memoria deduna en figura de cabeza de caballo, que pesó cuatro arrobas y libras y se envió al señor Carlos V., y de otra al señor Felipe IP como la cabeza de un hombre, que se perdió con otras muchas riquezas en el canal de Bahama. Aquella se halló en el primer lavadero decubierto en la Provinciu nombrada Inahua. ya por los fundadores de la Villa Imperial de San Juan del Oro, que fueron los españoles fugitivos de los partidos de Pizarros y Almagros, que penetrando quebradas y bosques se enriquecieron de modo que después de conseguir indulto del virrey Don Antonio de Mendoza, hacia el año de 1533, pasaron algunos a España con aquella pepita y otras grandes cantidades de oro y consiguieron de! Emperador muchos honores privilegios, pero abusando de ellos en contiendas de caballerías se formaron bandos, se destruyeron unos a otros y se destruyó la: floreciente Villa, que tenía ya por entonces más de 3,000 habitantes y hoy apenas llega a seis familias cie Indios y otras tantas de espaoles. Casi todo el suelo de esta Provincia parece que está mezclado con Oro Cuando se limpia el pilón de la fuente de la Plaza de Ayapata, se hallan en él briznas y aun pequeñas pepitas o granos de oro. También 
hay Minas de Cobre y de Plata en varias partes. Entre Corani y Ollachea esiá un Cerro, nombrado Ucuntaya, en que en 1709 se descubrió un Mineral de Plata tan rico que al principio daba 4,700 marcos por cajón. Su riqueza produjo muchos alborotos y muertes, que al tiempo que ponía remedio a ellos el señor Morcillo, Virrey de estos Reynos, cesaron, derrumbándose la Mina una noche y no ha habido quien haya tenido caudal y aliento par $x$ volverla a poner corriente. Hállanse en esta Provincia Manantiales de autuas calientes. El país de Ayapata, que es el más numeroso, es muy sano y se vive mucho en él. Hay muchos hombres de 90 y 100 años con la agilidad y robustez de 30 . Es territorio sujeto a terremołos. Según tradición hubo uno tan grande antes de la Conquista, que transtornó montes y abierta la tierra se hundieron muchos pueblos con sus moradores. $Y$ el año 1747 hubo uno tan grande, que abierta la tierra por algunas partes salía un agua cenagosa, que inficionando las de los ríos hizo perecer mucha gente. Se ven algunos ríos en esta Provincia mayores y menores, que van a desaguar a Inambari, río muy grande y confin de esta Provincia por el Norte y Nordeste con los Indios infieles, hacia donde hay muchos cocales y sementeras de Arroz con muchas y muy buenas frutas de Montaña. En este Río hay abundancia de Pescado, especiaimente Sabalos y Dorados grandes, que se pescan a tiros de fusiles y de flechas. Entra en el Marañón con otros, con el nombre de Ucayali. Hay también muchós] lagunas, peresin pescados; aunque si ccn aves, como patos, gallinetas y otras. Los indios Infieles han solido hazer algunas irrupciones en esta Provincia, en una de las cuales tomaron la Villa de San Gabán, que fué Capital de. Provincia. Tiene ésta 28,000 habitantes.

Comprende seis Curatos. El I es el de Sandia, Capital de la Provincia. Tiene ocho anexos que son: Cuyocuyo, Laqueyque, Nacoreque, Queneque, Patambuco, Chaquiminas, Pascata y Sayani. Estos tres últimos son de la jurisdicción real de la Provincia de Azángaro, pero recauda sus tributos al Corregidor de Carabaya. El II es el de San Juan de Oro, con dos anexos que son: Quiaca y Sina. El III es e! de Para, con dos anexos que son: Limbani y Chejani. El IV es el de Aporoma, que fué en otro tiempo anexo de Para y es frontera de Indios Chunchos. El $\mathrm{V}$ es el de Coaza. Tiene seis anexos que son: el Pueblo del Crucero, con un Santuario de mucha devoción de Nuestra Señora del Rosario, Ajoyani, Usicayos, Esquena, Cuntuquitu e Inambarí. El VI es el de Ayapata con cinco anexos que son: Ituata, Macusani, Ollachea, Azaroma y Corani. Sigue la 


\section{PROVINCIA DE LAMPA.}

Confina por el Norte con !a Provincia de Carabaya; por el Este con la de Azángarc; por el Sur con la de Paucarcoila y algo de la laguna de Chucuito; por el Sudoeste con la de Moquesua; y por el Oes?e con la de Arequipa. Tiene Norte-Sur 30 leguas y de ancho 20. Su temperamento es muy frío por estar la mayor parte circundada de Cordilleras nevadas todo el año. $Y$ aunque tiene muchos llanos o pam. pas, no deja de hacer mucho frío en ellas, por ser unas tendidas faldas de dichas cordilleras que siempre quedan bien altas. La prueba de esto es que en esta Provincia no se crían más frutos que Papas amargas, de que se hace el Chuno: y una semilla, como el Mijo y alguna Quinua, trayéndose los demás frutos de afuera, en cambio de Ganados mayores y menores, de que abunda mucho por la abundancia de buenos pastos. También hay Carneros de la tierra, Vicuñas y Vizcachas. Fabrícanse muchos Cosiales y Alfombres, en cuya especie, así como en Borregos. pagan los indios en muchos Pueblos sus tributos, Bulas y los obvenciones a los Curas. Estímanse por finas las lanas, dando re gularmente en la trasquila cada millar de Ovejas 70 arrobas de lana, que se vende a siete reales la arroba, la cual se conduce a los Obrajes de Quispicanchis y otros. También en el sebo tienen utilidad, pues por lo regular hacen matanzas, rindiendo cada 100 Ovejas de cuatro a cinco quintales de sebo colado, que se venden a 10 pesos el quintal, y llevando laJ carne, Iquitadoe li sebovehelada, que llaman chalona de esta Provincia, la venden a cuatro reales cada una. Estos son los frutos de comercio de esta Provincia, porque por lo que mira a minas, aunque las hay son de poca ley, y así apenas hay quien se dedique a ellas. Con todo hay algunos Trapiches de moler metales corrientes y se trabaja desde 10 a 22 marcos por cajón, pero sus costos son excesivos. Del antiguo Mineral de Vilavila también se sacan metales, y de otras minas que en otro tiempo fueron abundantes. De modo que, aún con todos estos atrasos, producen al año más de 15,000 marcos de plata. Hacia el Norte de la Provincia hay un Cerro bien alto, nombrado Caquenquerani, en el cual se halla una veta de Azogue bien abundarte, que se trabajó en tiempos antiguos. Hay una laguna hacia esa parte, de tres leguas de circunferencia, con mucha totora o enea, entre la cual se crían Conejos en abundancia. Hay algunos ríos en esta Provincia como el Ayaviri, de Nuñoa, y otros no muy considerables que van a desaguar a la Laguna de Chücuilo. En las lagunas se cría abundantísima caza de Aves, Conejos, Palomas, Tórtolas, Cu- 
yes, Venajos y Alcones. No hay bosque ni árboles de consideración $E r_{1}$ ioda esta Provincia. En la laguna de Chulpia se cria en abundancra un Pescado, que llaman Chini. Lo hielan los Indios, lo secan y lo llevan a vender en costales, a tres o cuatro pesos el costal. Cerca de Pucará, se ven las ruinas de un Castillo de los rntiguos Gentiles, de figura cuadrada, y dentro de él dos estanques hechos de piedras, a!gunas de tres varas de largo y dos de ancho. Cerca hay manantial de agua cariente. Óros Castillos o fortalezas moitratadas del ti=mpo, se ven en esta Provincia cerca del pueblo de Ayaviri. Hay un Lago din agua alien!e, cuyo fondo no se ha podido saber. Está siempre on igual aitır el aṣa, se cres que tiene desagüe subterráneo. A dos leguas de éste, hay otro Manantial de jgua caliente muy nociva. ill paso que corre se convierte en piedra, como sucede con la de Huancavelica. A distancia de cuatro leguas de! Fueblo de Santa Rosa, se halla un pozo que llaman del Inca. Su boca es como la de cántaro. Beben su agua los Indios, diciendo que es Chicha como la que se hace de Maíz, aunque algo insícida $y$ en el color no se distinque. Esta agua se discurre que pase por alguros veneros que la ponen de este olor, color y sabor. A. una legua de distancia de Atuncolla, Pueblo hoy el más desdichado de esta Provincia, habiendo sido en la antigüiedad la Corte del Gran Kolla, hay una Laguna grande dentro de la cual hay una Isla que tiene tres cuartos de legua en contorno. Se ven en ella los vestigios del Palacio del Dicho Rey. Es de figura triangular y de unas pledras formaables lal modo dé las de la fortaleza del Cuzco. Han destrujdgeestecriandei edificienlos „codiciosos de tesoros escondidos. Los habitantes de esta Provincia llegan a 37,000.

Comprende esta Provincia 13 Curatos. El I es el de Lampa, Capital de la Provincia, con un anexo nombrado Calapuja. El II es el de Cabanilla. El ill es el de Cabaña. El IV e sel de Mañazo, con un anexo nombrado Vilque. En $V$ es el de Atuncolla. El VI es el de Caracoto con dos anexos: Huaca y Llasin. El VII es el de Pucara, con un anexo nombrado el Asiento mineral de Vilorvila. El VII es el de Ayaviri. El IX es es de Orurillo. El X es el de Nuñoa, con un ane xo nombrado Santa Rosa. El XI es el de Macarí, con un anexo nombrado Cupi. El XII es el de Umachiri, con dos anexos que son: Llalli $\underline{y}$ Ocubiri. El XIII es el de Juliaca. Además de estos Pueblos hay el de Nicasio, que pertenece a la jurisdicción espiritual del Curato de Ca. minaca de la siguiente 
PROIINCIA DE AZANGAFO.

Confina por el Ncrdeste y Esie con la Provincia de Carabaya; por el Sudoeste y Sur con la de Larezaja; for e: Sucioeste con la de Paucarcolla y laguna de Chuctito; y par ei Oeste y Noroeste con la do Lampa. I:z Provincia corta, pues sulo tiene 20 legues de largo y ciras tantas de archo, aunque con irreju!nr figura. Su temperamento es muy frío, y asi solic produce pepas, Qtinua y Cañigua: y si éstas se hielan, lo yus surode algunos años, pican los Indios muichos trabajos, síndoles fozzoso rezurrir a la Frovincia de Larezsia por bastimentos. Pero es ahundantisimo de Genedos, gue es su prinzipal comercio, y en lancs y sebo y algunos Cerdos. Tiene una laguna salobre, de don de se proves de Sal la Frovincia. En el Cerro de Ananco se trabajan Minas de Oro, que solo dan cirico o seis mil casteíanos al año. Dió mucho en otro ternpe. Hoy lo mbarazan las nieves. El río más considerable es el de. Azángarc, que desagia en la laguna de Chucuito. En el Pueblo de Pusi hay ur manantial, en cuya agua reposada sobre nada un aceite que sirve pará alumbrarse. En Asillo hay una Mina de Plomo, que se comercia ora las fundicicnes de Plata a otras Provincias. Los habitantes de esta corta Provincia solo liegan a 3,000.

Comprende nueve curatos. El I es el de Azángaro, Capital de la Provinciz, con tres anexos que son: Muñani y los de minerales de oro, Poto y Annecr. El II es el de Asilo. El IIl es el de Santiago de Frxpuja. El IV es el dé Arápat com un anéxo que es la Villa de Betanzos. El $V$ es el de Caminaca con dos ànexos que son: Achaya, en esta, y Nicasia en "la Provincia de Lampanvel"Wh" es el de Saman. El VII es el de Taraco. El VIII es ol de Pusi. El XI es el de Chupa, con una anexo nombrado Putina.

\section{EL LAGO TITICACA (29)}

Este Año damos las Relaciones de las Provircias del Obispado de La Paz. Las más de ellas están situadas a la orilla de una laguna, que a la primera vista admiraron mucho los Conquistadores. Creyeron que en medio de estas tierras había un Mar sin comunicación con el Océano; pero al verlo de agua dulce conocieron que las aguas de una $y$ otra Cordillera, no teniendo libre corriente, formaban detenidas esta hermosa balsa, que teniendo más de 50 leguas de largo y por partes

(29) El Conocimiento de los Tiempos. Año 1770.2 pp. iniciales y 55.

En tipo pecueño se pone la parle que corresponde hoy a Bolivia; y en tipo corriente las provinciés que forman el Perí aclual. 
más de 25 de ancho, excede a muchas de las más celebradas de Europa $Y$ aun de todo el Mundo. Fuera muy estimable si los habitantes sus vecinos fueran más numerosos y no tuvieran puesta la atención en otros asunios que, en las presentes circunstancias, contribuyen principiamente a su conservación. Por el primer motivo hay poco comercio entre estas Provincias, siendo por esto casi inútil su navegación. A esto se agrega io rígido del temperamento, porque estando todo su terreno sn unci considerable altura que llega a lo menos a media legua de la superficis del mar, hace poco apetecible su habitación. Ni hay con que librarse de los molestias del continuo frío, porque en todas estas Provincias apenas hay leña ni carbón, haciendo que sus moradores se valgan de todos los arbitrios que les sugiere la necesidad, pues se ven obligados a echar mano de la buñiga de los ganados para las cocinas y para calentarse en vez de leña, sufriendo la incomodidad molestísima del humo. En algunas partes se valen de céspedes para lo mismo, cuyo humo no deja también de molestar mucho. Demás de esto, los vientes son impetucsísimos lo más del año y como pasan por los Cerros nevados de la Cordillera/ causan excesivo frío. De la antigíedad de la laguna no hay noticía. Antes de la fundación de este Imperio existía ya. Con todo es verosimil que se hiciese por algún grande terramcto de los muchcs, que según las tradiciones de los Indios hubo en estas partes. Er su fondo es muy natural que haya mucha riqueza. Muchos de los ríos que le entran, bajan de lugares en qua hay minerales de lorot $\vee$ plata. Lads demás Sparticularidades se pueden ver en la descripción de icada Provincia.

\section{DESCRIPCION DE IAS PROVINCIAS PERTENECIENTES AL OBISPADO IEE LA PAZ.}

El Obispado de la Paz, erirido en 1608, comprende sjete Provincias, que son: ia de su nombre, Sicasica, Pacages, Omasuyo, Larecaja, Paucarcolla y Chucuilo. La Ciudad de Nuestra Eeñora de la Paź. lomó esie nombre por haber sido funciada despues de sosegados los alborotos del reyno en 1548, por órden del presidente Gasca. Por esis en la orla del estandarte en que están sus amas, que envió Carlos $V$, se lee: Los discordes en concordia, amor y paz se junlaron, $y$ pueblo de Paz fundaron, para perpetua memcria. Tiene su asiento en un sitio áspero del valle de Chuquiabo en 179 $30^{\circ}$ de latitud austral. Su temperamento es frío y su cielo tormentoso, por estar a tres leguas de la Cordillera. En sus contomos solo se dan frulos de Sierra: Papas, Cebada * algunas Verzas. Es dividida su población por un Arroyo, que baja de la Cordillnra, de buena agua; el cual se pasa por tres puentes de cal y piedra de solo 
un areo. Las más casas están cuibiertas de trio. aun con no tenot mitio costo bis madc-

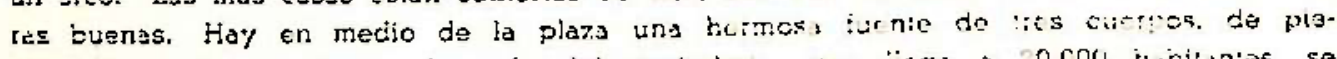

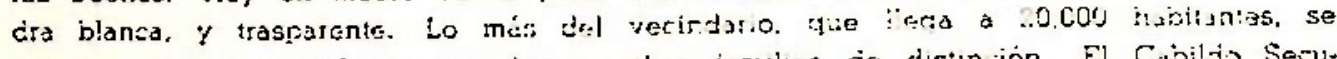
compone de gente vulgar: pero hay muchus ismiliss de distuncion. El Cibildo Secular, a guien preside un Corregidor, se compone de acs Alealios Ordinatios: do Regi-

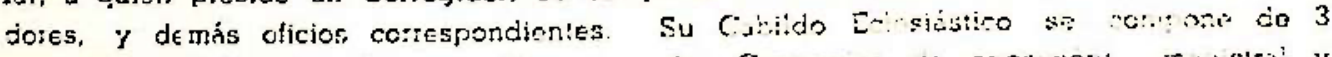

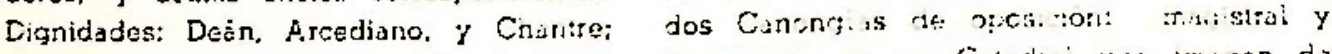

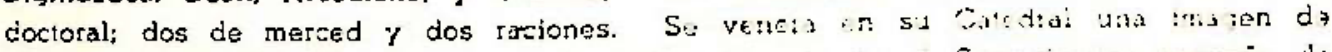

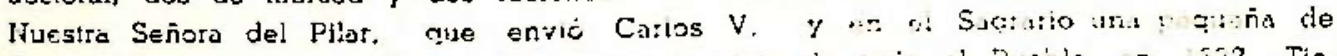

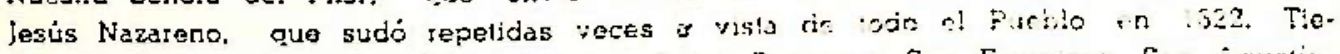

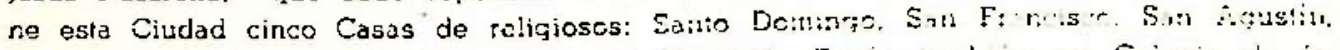
la Merced y San Juan de Dios, con un ilespitai. Iritis anton un Coirgio de je-

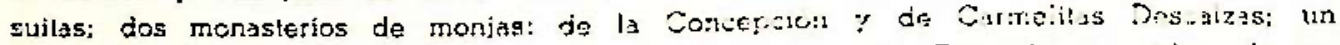

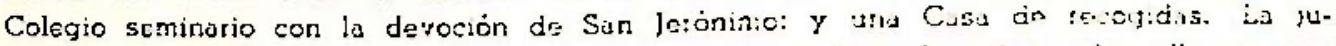

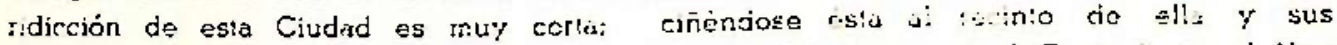
arrabales. Contina por el Este con ha provinria ce Si-asicd for fi Caste hista ol Norte con la de Omasuyes; y por el Sur y Sudoeste con la di Priages; per e! Sudoeste con la de Larecaja. En casi lodo gste Obispado usan los Indios al Licuid. gu llaman

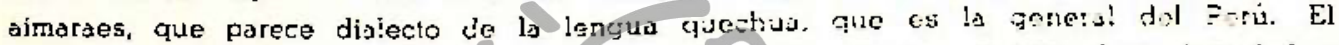
nombre del ville de Chucuiabo viene de Choqueyayu que cuiare decir tisejad o sementera de cro, porque conctieron los antiguos que en los contornos de sale yilie habia mucho de esle matal. Sea prueca de esto el fievacto corro de limeni; del cual se ha sacado innumerable squeza. despuśs que en 1681 dertito un rayo in crestan de la cordillera, en qus está. Tadavia se sacan abuncs marcos de oro en sus inmediaciones.

Comprende esta Cjudad cuátro curatos: el de Saglario, servido por dos Ciliss; al de San Pedro: el de San. Sebastián y el de Sunta Bárbara. Sijue al Este la

\section{FROVINCIA DE SICASICA Irge Puccinelli Converso"}

Conlina por el Norle y Nortesle con las monturas de los Andes y provincia de Larecaja por el Este con la de Cochabamba; por el Sudesie con el Corregitmiento de Oturo y provincia de Paria: por el Sur loda alguna parle del río del Deságuadsio: for el Sudoeste con la provincia de Pacages; y por el Noroeste y Oeste con la Ciudis de la Paz. Esta es una de las moyores Provincias del Perúi pues para la aciministración de justicia recesita el Corregidor 12 Tenienles Corregidores, $\gamma$ uno genera!. Tiene de Norte a Sur 50 leguas. y del Esle al Oeste 80 . Su temperamento es vatio, pues por unas partes hay serranias muy frias, en que se crian toda suerlo de Ganzios, en un grán número de Estancias, que hay. Por las pattes, que toca a los Andes, as muy caliente. y húmeda. Por estas parles es muy lértil y abundante de lodas fruas. Canaverales de azúcar. Haciendas de Coca, de que se hacen un gran romercio: porque se ha propagado el uso de esta hoja, que sćlo la usaban los Indios. a los Españo les de uno y otro sezo, y a todo ginero de gentes: de modo que. valiendo en olros liempos un cesto cinco pesos, en estos llega a venderse a 10 y 11 pesos. Tambjén se cultivan Viñas, de que se coge Vino. Riega a esla Provincia el rio de la paz, que es el origen del río Beni, oue púsa por el Pueblo de los Reyes, el más cccidental de los Moxos. Ademós de dicho río, hay otros, que descienden de los ramos de la cor- 
diliers. que en tiempos de aguas son caudalosos. Por el río de Coroyco se empieza la nuvegación para el Fueblo de Reyes en balsas. Enlre los producciones de esta Provincia debe contarse la Cascarilla o Quina, la cual es lan buena y eficaz como la de icia. cono herros experimentado en Lima. Desie al arroyo de Mejavire, qua divicit: al arrabal te Santa Bátbara de la Paz, comienzz esla Provincia; y en un feque ño Viliz, cie riega, hay algunas Casas de recreo o Quinlas, perterecienies a elgunos vecinos do aqueila Ciudad. Este Valle, de buen temperamento, corre hasla el antigus mi:itial de ore. llamado Chuapiahuillo, en la falda de la Cordillera, en dende se hallo aquella ri.s pepita, que pesó 90 marcos. Es la major que se haya hallado en esto Ficins. Tiere ha especialidad de quilala por losise partes, se le hallaron seis loyes distintis, descis 18 hasts 23 y medio quilates. Se avaluo a 20 reales el castoliano. Impe:tó 11.269 pescs. 3 resles y madio. Se compró de cuenta de S.M., quien la rinitió ecs eprecio y agradecimienlo al Virrey Marquós de Castelluerle, en cuyo icmpo se hallo y remitió al Rey. Por las tierras de los cinco Curálcs de Andes so fijcan je los reitios boscites muy buenas maderas rara fábricas: cedres, cocobolos. elc., y también frutus varias y Tabacos. En esta Provinzia hubo Minas muy ricas de Plata y Oro: y aun en el cerro de Santiago, y otros, las hay: pero fallan ánimos que coslect los preparativos para trabajarlas. En dicho Cerro hay la particularidad de hallarse en unj misma Mins, y aun en una misma veta cro y plata. En el asiento de Harasa hay un Mineral de crc, que rinde hoy poco. De las lanas da les Ganados se labra en esta Provincia alguna ropa de la tierra: pañstes, bayelas y frazadas. Hay aquí un Pusiblo, nombrado Cellana, anexo del Curato de Mecapaca, cuyos Indios desde la Concpuista ro se han querido mezclat con ninguna olta casta; y para evilar esto no dejan domi: en el Fueblo forastero alguno, aunque sea onviado fcr el Corregidor, sino en un rancho apartada, on que ponen tonda; $Y$ si entra alguno lo llevan a la cárcel. donde lo tienen pocas horas, pues en breve to despachan. No se ven en este Pue. blo los vicics y malas propiedades, que selobseryar.generamenle en todos los Indios. Son de vida muy arreglada pagar sin gue sel les cobre y 50 gobieman por campana. Puede servir a todo el reino de ejemplo su conducla. Aunque hace algunos años que 110 resibe esla Provincia daño alguno de los infieles, que habilan las monlañas de los Andes, no cbstante se tienen centinelas avanzadas o uros deslocamenlos, que hacen guardia en sus frenteras para impedir que hagan hostilidades que en olro liempo ha ciar. Los habilantes de esta Frovincia pasan de 50,007.

Comprende esta 16 curatos, que son: El I es el de Coroyco. con dos anexos que son: Huayrassila y Colypota. El II es el de Yanesha, sen tres anexos que scr: Chupe, Millusiay y Choxlia. El III es el de Chulumani, cen des anexos nembrados líxma $Y$ Chirga. El IV cs el de Laza, con un anexc nombrado Irupana. El $V$ es el de Zuri. Estos cirso ciaen hasia la Monlaña de los Andes. El Vl es el de Crsbari, con dos anexcs nexteredes Copiñita e Inquisne. El VII es el de Mchesa, que enlra nue. ve leguas en la Provincia de Cochabamba. Tiene un anexo, r.mbrado Cclquite. El Vlil es el de Yaco, con dos anexos nombrados Icheca y Quimi. El IX es el de Luribay. con un anexo nombrado Haraca. El $X$ es el de Sicasica, carital de la Provincia. Ei XI $\varepsilon z$ el de Haychayc. El XII es el de Calemarca. El XIII es el de Zapaaqui. El X̌IV en el de Caraccto. El XV es el de Mecapaca, cen des anexos nembrados Cconi $Y$ Collana. El XVI es el de Falta, con un anexo nembrado Ccavaya. De estos Curatos pertenecen al Atzchispado de la Plala: Sicasica, Laribay, Yaco, Mohosa y Carabi. Por la parie del Sudoeste sigue la 
Confina for el Norcoste con la provineia de Chucuits. Por cl Norte con le gras Laguna de Titisaca; por el Nerdeste een la Provineia dro Omasuyes y siguiendo para el Este con la Ciudad de la Paz y Provincia de Sicasiza: por el Sulieste con el Co regimiento de Oruro y Frorincja de Parie; fro: el Sur con la de Caranzas; por el Sudoeste y Oeste con la juriscieción cle la Provincia de Arica, nediando les cordillora. Tiene de largo desde el puenie de! ric del Dasarnadero, cue la divide de la Provincia

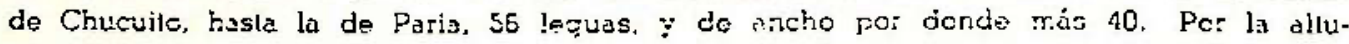
ra de su terreno. Y por esiar a la vish de laz dos cordilleras nevadas. es frio $y$ dosagradable su lemperamento. Por esto es fórtil; y sus trutos son, por lo comun. Papas dulces $y$ amorgas, te que so hars si Chuño. Tutrbién se ccqen abundantes ccsechas de un grano, que lleman Cañihua, que sirve do alimento, y de que se hace Chiccha.

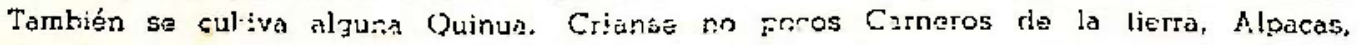
Vicuñas y Viscachas. Horg muchas Estenciar de Ganado ovejuno, do cuya leche hacen quesos muy bucnos. De las Oveins modres, 7 a viejas, se hecen anualmente malanzas. que salajas $y$ endurecitas sua cimes con el hielo, se llaman, en el Perí, Chalones. Estas, con porción de Chuno, se llevan a las Provincias de la Costa de donde en cambio traen Vines. A.juardientes y Algodinn: y de la de Cochrbamba, Maiz, Harinas y otras semillas. Hoy ro so trabêtan Minas algunas en esla Provincia. Anliquamenle fué cpulenta. cuando se labraban en muchas partes de ella. Las de Berenguela fueron de las más antiguas, poderosas y cópbres de! reino, con 700 velasi en cuyas cercanías hubo, secún manifiestan los vestigios. una Población de Españoles. A una legra de este lugar, en e: Cerro nonbraclo Collipsuma. se halla nucho eristal de roca en. granos, que parecen diamontes; $y$ en el de Aconsaja los hay verdes, que parecen

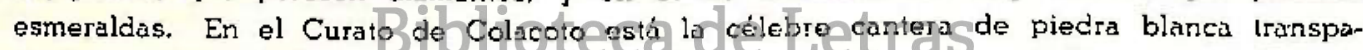
rente, especie de alabastro, que llaman de Berenguela, ta cusl so halla en otros Provincias, como en la de Portoslyg Cochabambalsirveseldelelanon gran parle del Reino para claraboyas, gradas, fuentes y varios utensilios. Beneficiose en esta Provincia Sal, de un riachuelo, nombrado Hayuma, con que se abastece esla Provincia y alqunas comercas. Riegan esta Provincia aljuros arroyos. Entre e!los el mayor es el rio do Maure, cuyas aquas descienden de la Cordillera de la Costa, y van á dar al rio del Desaguadero. Este corre todo el largo de la Provincia. Noroeste-Sudeste. Sale de la larguna de Titicaca o Chusuilo y termina en la Frovincia de Paria, formando una laguna, donde se sumerge y va a selis. por debaio de la cordillera, haria el puerto de Iquique. y según alqunos, da origen también al rio de Loa, que divide las dos Provincias de Arica y Aldcama. Al selir este prolundo Ric de la laguna de Chucuito, tiene algo mas de 61 varas de ancho y cliatro braras de prolundidad. Alli está un puente herho de 24 balsas de totora. o eneas, de cerca de tres varas de ancho y otro tanto de grueso. En una y olra orilla hay Pueblo de Indios, que renueva el puente crda seis meses. Cría esţ Río alizín Pescado. de que se ahaslece esta Provincia. Su curso es tan lento, que apenas se percibe. Es muy probable que la gran laguna de dorde nace, ne desaçua torlas sus aguas por él. Porgue la laguna, fuera de muchos arrcyos, recibe die: rios. de les ruales alcunos exceden en agua al del Desaguadero. Debe pues tener otrcs conduclos sul-lerráneos para conservarse siempre en mismo eslado. Dos lagunas pequeñas, y contiguas, hay en esta Provincia, no lejos del pueblo de Achocolla: las cuales. según constante trasicicin de lodas estas Provincias, tuvieron 
el mismo origen qu el lạc $x$ sfaltites en la Palestina, en donde castigó Dios con fuego el mismo delito de que estahan infecta.ios los. Indios habitantes del Pueblo, que aquí hubo 20r. años hacs, nombraio Anro. El único monumento que hay en esta Provincia de sus antiguas grandezas, es el gue se halla a cuatro leguas de Tiahuanaco, en los vestigios del poder y magnificencia de los Incas. Se ve un Cerro bien alto, hecho a mano sobre qrandes y funrtes cimientos de pisdra, y cerca de él las ruinas de un Saion, en que se ven piedras de nueve varas de largo, 6 de ancho y de grueso, labradas con tal jrimor y ajustes, que se deben iener por prodigios de la industria. No hay en los contorncs peñas ni canteras, de donde se pudiesen haber cortado. Están estos vestigios cuatro leguas distantes de la laguna cie Chucuito. Tiene esta Provincia 2.5.000 habilontes.

Comprende 12 Curatos. El I es el de Caquiaviri. El II es el de Viacha, con un anexo nombrado Achocolta. Fl I!: es el de Tiah:ıanaco. El IV es el do Huaqui, con un anexo nombrado San Pe:iro drl Nesaguadero. El V es el de San Andres de Machaca. E! VI es el de Jesús de Machaca, donde hay un Beaterio de $12{ }^{\circ}$ beatas franciscariss. El VI! el e! de Santiago de Machaca, con un anexo que es el de asiento de San Juan de Berengue!a. El VI!I es el de Calacoto. El IX es el de Caquingcra. El X es el de Callapa. 드 XI es el de Curahuara de Pacages. El XII es el de Hulloma. Estos tres últimos perienecen al Arzobispado de la Plata. Sigue al Norte, y Nordeste la

\section{PRONVINCIA DE OMASUYOS.}

Confina por el Norte y Noroeste con la Provincia de Paucarcolla; por el Nordeste y Este con la de Larecaja, mediando los altos y cordillera que llaman de Acuma; por el Sur con la Ciudad de la Paz y Provincia do Pacages; y corriendo por el Sudoeste confina con là lac̣una de Umamarca, brazo crande, la principal del Titicaca, pues se comunics por el es:rec'.o de Tituina: $Y$ por el Oeste con la gran laguna, en cuya parte cccidental hay una legua de tierra mediando lä laguna perteneciente a esta Provincia, que confina con la de Chucuito. Tiene de Norte-Sur 40 leguas, y de ancho 16 a 20 al contrario rumbo. Su temperamento es frio; aunque uno u otro Pueblo de los de la ribera de la gran laguna, gue corre lo largo de esta Provincia, son un poco templados. Críanse en ella todo género de Ganados y algunos animales silvestres, como son: Vacas, Mulas, Caballos, Ovejas y Cerdos, Huanacos, Vicuñas, Raposas, Viscachas, etc. De las lanas de los Carneros fabrican los Indios costales, bayetas, pañetes y cordellates, y de la de los Carneros de la tierra o Huanacos, hacen varios tejidos para sus vestuarios. Tiene esta Provincia varios Ríos, que le bajan de la Cordillera y entran en la gran laguna, abundantes en tiempo de aguas. Sus frutos son: Papas, Ocas, Quinua, Cañihua, Habas, Cebada; y en alounos parajes algo templados se cultivan Verzas y flores. Cerca de Tanahuacas se ven los vestigios de un gran castillo o fortaleza del tiempo de los gentiles. Es de piedra, y da vista a la gran laguna. Tiene en una plaza cuartos y viviendas del mismo material. La laguna sufraga mucho Pescado de varias especies y muchas aves acuáticas, que se crían en los totorales, de que abundan sus orillas, islas y ensenadas. Entre el Pueblo de Luaycho y el de Carabuco hay una Capilla arruinada que estaba dedicada a San Bartolomé; donde, según tradición muy antigua, se aparreció este Santo Apóstol a predicar a los gentiles. En el altar mayor de Carabuco hay una cruz grande de madera muy fuerte, rue hace portentosos milagros, cuyas astillas solicitan los fieles para cruces para librarse de muchos peligros. Se cree haberla de- 


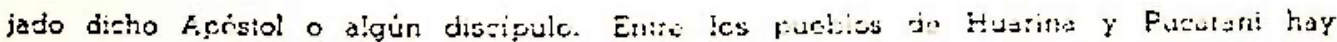

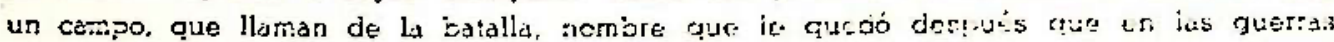

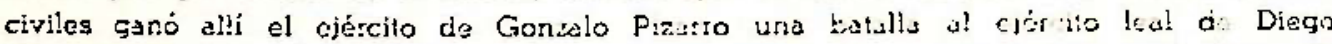

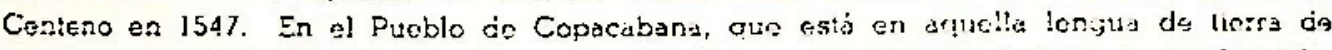

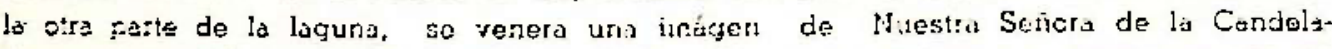

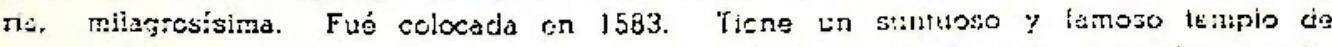
mu lucida arguitcctura adorno $y$ rioucza. Es el Santuaso de rás devosian y culto

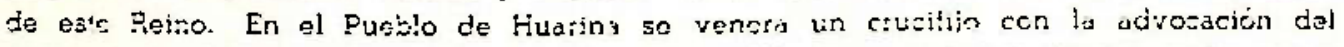

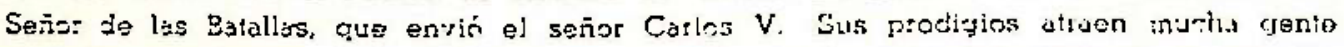

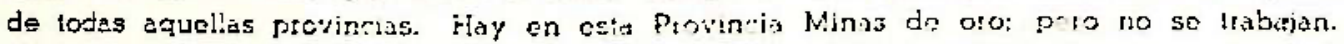

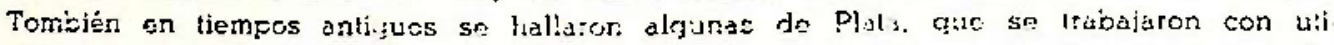
lidad. Pertengce a ester provincia la Isla do Titiesca. lo mas celetio y notable de la la.

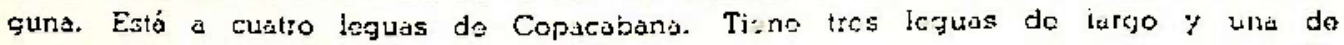
ancho, con 13 quebradas regadas do exquisitse aqués, ? ägumas hariondas bien culli. radas, que por el temperamento menos rigidr, producen alaunas semillis, flores, $Y$ írutas, $y$ se cía Ganjites. Cenciea silvesires y Pulrmas. Por los vestigios que han

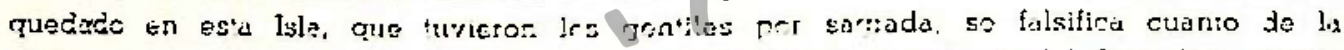

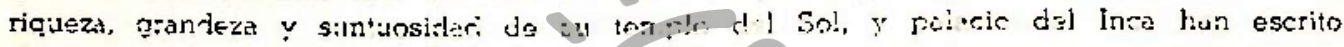
alguncs. Al fatbuloso origen del primer fundazor do estle tmpcrio. miandicion los in. dios otras mil fabules. Menos que no so diga que estos lo demolieron lodo a la entrada de los Esceñoles, y arrojaron a la laçuna las dacantadas ficuezas y dún hasla la úlima pio.

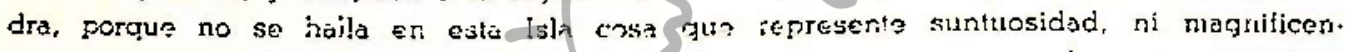

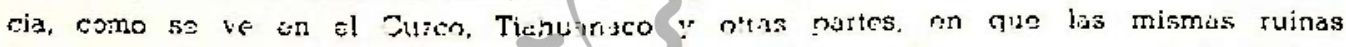
demuestran la grandeza de sus antiguas edificios. Esta gran laguna es capaz de llevar todo ánero ds embarcaciones. $Y$ un Corregidor fabricó, poros āñas hace un hemoso berco, qus navegaba bits a todts les Pustes de las vecinas Provincias. Antes se vieron en ella otros de iotal mene-o. Les hatiantes de este Provincia llegan a 45.000.

Comprende ocho Curatos. El I es e? de Huaycho, con un anezo nombrato Santa

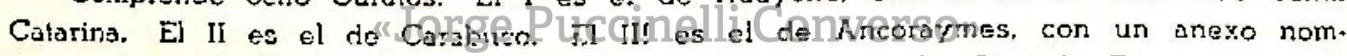
Erado Santa Lucia. El IV es el de Achacache, cue es la Copilal. Tiens, separada

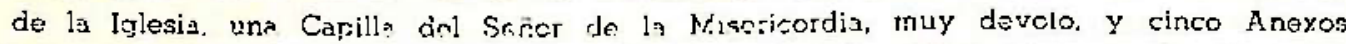
que son: Tajora. Iscacachi, Ancoamaya, Santiago y Belón. El V cs el de Huarina. con dos Curas, y un anezo que es e! Sinfluario do Nuestta Señora de las Pañas. El VI es el de Pucarani, con dos Curas. E] VII es el de Lácsa, con un anexo nombrado Llocilo. El VIII es el de Copacabena. con un anezo nombrado Tíguina. Por el Nor. deste sigue la

\section{PROVINCIA DE LARECAIA.}

Confina por el Norte, $y$ Nordesle con las montañas dis las Indios infieles, casi al Sur de las misiones de Apolobarnba; por el Sur con la Ciudad de la Paz; por el Oeste con la Provincia de Omasuyos, mediando la Cordillera; y siguiendo hacia el Norte con las de Paucarcalla, Azángaro y Carabaya. Toda esta Provincia es como una quebrada, que va de Norle a Sur hasta encontrar con las lierras montuosas do los Infieles, por donde abre mucho. Tiene muchos arroyos, que forman un Río caudaloso que entrando en la Montaña, van sus equas a juntarse con las del rio Beni. Tiene de longilud 36 lequas y 10 de ancho; aunque si se toman las dislancias por elevación. 
ajenas tientu la mitad de unj $y$ olta. Es de siluación desigual, por los muthos cerros $y$ birlancos. Aquolios cubiertos de nieve ledo el año. No cbstante, los pueblos son sanos y de un le:mperumento medio. A las taldes de les Cerros se cultivan todas sewillas y frias. Y bicie los Andes sc coje aljuna boca y los frutos de Montaña. En al. iunos purajes de la Piovincia se crial de todos Ganados, con que se abastece ésta. en el disitito de Quialaya. y en alyunos otres lugares. hay varios Minerales de Orc que cn oiros tiempos fuercn tuuy pingües. Hoy apends hay quien los trabaje, inás por falla de áninics $y$ caudiolos, con eue hacer los gastos previos a las labores, que por tulta de Miris. Cen lodo no dejin de sacarso algunas cantidades algo considerables. For la puite de la montuña de los Andes están las Misiones, que vulgamenle llaman del Gron Pailiti. de Misioneros aqustinos, en qua hay cinco poblacienes de Indios convertidos, quo de algutios añes a es!a parte pagan Tributo, aunque corto, a S.M. en las Calas :ejies de la Saz. Les pueblos son: Huesunatre, Tipuine, Mayire. Chinijo Y Consatu. Tcdos con bion pocos habilantes. Incluso estos. tiene toda la Provincia 20,000.

Comprende it Curalos. El I es el de Zorata, que es la Capilul, por resicit ordinarituncent= alli el Corrogidor. Tiene un onexo. nombrado Tusuaya. El Il es ei de Sonro. El Ill es el de Cinallana, con dos anexos que son: Symaco y Chacapa. II IV es el che Quitabiya. El V es e! die Hjabaya. El Vl es el de Combaya, con cuatro anexos cine son: Chiacuni. Curasani. Cumbili y Coale; y también un Suntuario de Nuestra Señora nonibrado Cluchulaya. El VIt es ol de Ambaná. con seis anexos que son: Co. paiçus. Cusahasya. Tiuusi. Sococone, Chaclaya y Punama, El VIII es el de Italaque. con dos aric:os que son: Limanala y Yocarbaya. El IX es el de Mocomoco. El $X$ es el de Chuma. con un anexo nombrado Patazcachi. El XI es el de Ayata con dos Anexos que son: Yanabaya $y$ iluacapala. Ei XII es el do Charazani, con cinco artexos que son: Anurete, Chajaya, Chulina, Curba y Onobamba. El XIII es el de Ca* mala, con un ancxo nombrado Carijama. El XIV es el de Pelechuco. Este Pueblo fué anexo de Charazani, unieniras fué de RegularesesieCuralo. Sor muerte del úlimo Cura Iranciscano se dividió en dos. Por el Noroeste, $y$ Oeste sigue la "Jorge Pulcclnell Converso»

\section{PROVINCIA DE PAUCAROLLA (30).}

Confina por el Nordeste con la Provincia de Carabaya; por el Este, rodeando la parte septentrional de la laguna de Chucuito con la de Larecaja; por el Norte con la de Lampa; por el Sudeste, al otro lado de la gran laguna, con la de Omasuyos; por el Sudoeste con la Cordillera de la costa; y por el Sur con la de Chucuyto. Su longitud es de

(30) El Conacimiento de los Tiempos. Año 1770. Parte correspondiente al Perú: Paucarcolla $y$ Chucuito.

Por Real Cédula de primero de íebrero de 1796, se roincorporó al Perú la Intenden. cia de Funo. cayendo bajo la jurisdicción de la Audiencia del Cusco.

v. Real Cédula á la Audiencia de Lima sobre agregación de la Intendencióa de Puno al Virreinato del Perú, y el todo de su distrilo á la jurisdicción de la nueva Audiencia del Cusco 1790-11-1, en "Arbitraje de Limites enlro el Perú y Bolivia. Prueba del Perí.". Barcelona, Imp. de Henrich y Comp. 1906. Tomo XI, pp. 391-393. 
68 leguas, y 28 de ancho. Los principales Ríos, que la bañan son: el de Suches, que bajando desde el camino de Arequipa, atraviesa la Pro vincia de Lampa, y entra en la laguna cerci del pueblo de Copachica, el de Taraco, que baja de la de Azángaro, y juntándose con el do Huancané, que viene de la misma Provincia, entra en lu laguna a tres leguas del pueblo de Huancané. E! tempezumento de esta Provincia es generalmente frío. En las partes inmediaias a la laguna se cultivan papas, quinua, cebada y otras semillas de puna. Lo general, en que se ocupan los naturales, es en criar ganados vacunos, ovejunos y de cerda. También crian Carneros de la tierra o Llamas. Hay no pocas Vicuñas, Venados, Viscachas, Cuyes, Ferdices y aves de la la zuna. De ésta se proveen de pescado, corno en las demas Provincias situadas a sus orillas. Hacen viajes a las de la Costa, llevendo Chuños y carnes heladas; y trayendo vinos, aguardientes y otres fruios de costa. De las lanas de sus ganados tejen las Indias sus ropas; dandole varios tintes. Su capital fué el pueblo de Paucarcolla. Pero por haberse disminuido mucho el vecindario de este lo fué el de Huancané. Después del descubrimiento de las minas del cerro Layccicota, sirvió de Capital, desde el año de 1657, el asiento de esto mineral con el nombre de San Luis de Aiva, hasta el año de 1668, en que el virrey Conde de Lemos, pasando a esta Provincia a sosegar las inquietudes que en ellas había, mandó asolar tabpoblación de dicho asiento, que se componía de más de 3,000 casas; y señalo, con título de villa, por capital, el pueblo de Puno, con el hombre udeligedoncepción'spisan Carlos de Puno. Antes se llamaba San Juan Bautista. Dista de la Ciudad de Chucuito cuatro leguas. Fué esta Provincia opulentísima de plata, especialmente desde el año de $165 \%$, en que se descubrió Laycacota, que es lo mismo que laguna encantada; por tener una en la parte superior, formada por los Indios antiguos con el fin de ocultar su riqueza. El Maestre de Campo don José Salcedo, llevado de algunas noticias vagas, y disgustado de habérsele debilitado las labores que tenía en el cerro de San José, mandó a su gente que fuesen a trabajar al de Laycacota. Quebraron un crestón, y reconociendo melales buenos, dieron un barreno á la laguna con lo que se hizo paiente la veta, y en ella una inmensa

v. Exposición de la República del Perú presentada el Excmo. Gobierno Argentino en el juicio de Límites con la República de Bolivia, coníorme al Tralado de Arbitraje de 30 de Diciembre de 1902. Exposición del Perú, en "Arbitraje de Límites en. tre el Perí y Bolivia". Barcelona. Imp. Henrich y Comp., 1906. Tomo I. pr. 1-64. 180.183. 
cantidad de plata blanca, que se sacaba a poca costa. Se abrieron otras bocaminas, la de las Animas y Laycacota la baja, en menos de una cuadra, igualmente ricas. De esta última sacó en una noche Gaspar Salcedo 93 botas, avaluadas en 100,000 pesos. También es constante, que se sacó de esta mina una piedra de plata maciza, que después de desbastada mucho, porque no cambía por el camino, pesó siete arrobas, tan limpia, y sin mezcla, que pagado el quinto al Rey se le puso el cuño como a barra. Levántanse a los lados del referido cerro los de Cancharani y San José, que se han trabajado con grande utilidad, particularmente el primero. Termina por la parte del Norte de los referidos cerros, el que llaman del Azogue, por tener vetas de este metal, que en tiempo del Conde de Alva se benfició, excediedo su calidad y abundancia al de Huancavelica. Pero por motivos que habria para ello, mandó el superior Gobierno que cesasen sus labores. Desde entonces nunca se ha dejado de sacar plata de estos cerros. $Y$ aun se sacan mas de 50,600 marcos al año del de Cancharani. Los Indios de algunos pueblos de esta Provincia, que crían ganados, tienen el comercio de llevar a los Ingenios y trapiches de los minerales, mucha buñiga, que ellos llaman Taquia. Como en estos parajes hay carestía de carbon y leña para quemar metales, sirve este género en su lugar. Esto mismo se practica en otras Provincias de igual temperamento. Cerca del pueblo de Goata se ven tres cerros de tierra, hechos a mano, como de 20 varas de alto. Es fradición que en uno de ellos fué enterrado el tesoro del GrargCollacalltiemp6 que los Incas conquistaron este país. Por parte del pueblo de Capachica se ven en la laguna das islas: la una nombrada San Miguel de Amantañi, y la otra San Rafael de Taquila. Una y otra de tres leguas de circunferencia. En lo más alto de ellas hay llanos en que se ven, aunque maltratados, algunos pueblos antiguos grandes, con la particularidad de ser las casas uniformes, fabricadas de piedra, bóvedas de los mismos. azoteas y plazas, todo muy regular y primorosamente construido. Dichas islas producen en huertos y jardines, algunas verzas, y variedad de flores. Tiene esta Provincia 26,000 habitantes.

Comprende ocho curatos. El I es el de la Concepción y San Carlos de Puno, con dos iglesias: una de Españoles y otra de Indios. Tiene un anexo, nombrado San Pedro de Icho. El II es el del pueblo de Paucarcolla. El III es el de Tiquillaca. El IV es el de Coata, con una Iglesia muy frecuentada, dedicada a la presentación de Nuestra Señora. El $\mathrm{V}$ es el de Cápachica, con un anexo, nombrado Iscallani. El VI es el de Huancané, con una Capilla, dedicada a una admirable Ima- 


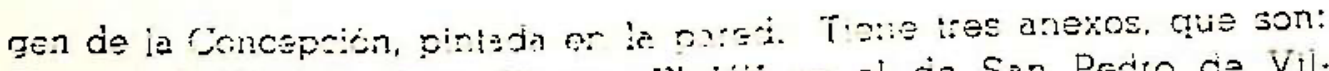

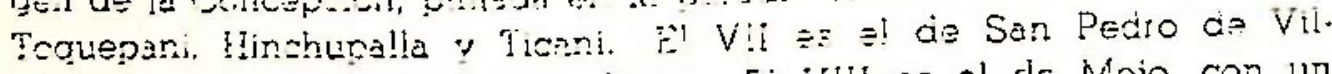
gues, con un anero ncrnorado Coata. E: Vlll es el de Mojo, con un anexo rombrado Conima. Sigue ai Sit iz

\section{PROVINCIA LE: C'HUCUITC:}

Confiria por ei Fiste con la gran lijura y con a'go de la Frovincia do Omastyos; por il Nrire con le tie Puzurcoila o Puno; por el Sudeste con la de Pacages; $v$ por el Sudoeste y Oeste con la Cordillera de la Cos!a, que mira a Moquegua. Tiene Norte-Sur 25 leguas y 36 de ancho. Estaba esta provincia muy roblacia al tiempo de la conquista; y así se consideró desde el principio pcr opulento. Tuvieron sus Governadores el mando político, vicepatronato y Capitanía general de las Provincias inmediatas, incluses algunas de Costa. Su temperāmento es frío pero saludable, particularmente en loz meses de lluvias Diciembre, Enero, Febrero y Marzo. Lás cosechas son genera!mente de papas dul. ces y amargas, de que se hace Chuño, Quinua, Cañihua y alguna Cebaca para pastos. En algunas quebradas abrigadas se cuitivan legurn. bres y aun flores y algunosárboles frutales. Hay abundancia de ganados, Vacas, Ovejas y Cerdos, también de Llamas o Carneros de la tierra, con que trafiçan los naturales en lugar de jumentos, cargando cada uno de cuatro a cinco arrobas. Hallanse tamién Alpacas, Huanacos, Vicuñas, Venados, Euyes Yl Vizcachas, Gliese parecen y saben a liebre, Palomas, Perdices, muchos Patos y algunas Avestruces. De las lanas de aquellos animales fabrican las Indias varios tejides para vestuarios y galas, en que se emplean varios tintes. De la lana de las Alpacas hacen Sobrecamas, Mantas y Alfombras de varios dibujos y labores. Corresponde a la Jurisdicción de esta Provincia el antiguo y poderoso minerál de plata de San Antonio de Esquilache, situado casi al Oeste de la ciudad de Chucuito, en la fría y doblada cordillera, que corre desde los límites de la Provincia de Paucarcolla hasta la de Pacages. Este mineral dió inmensas riquezas; y aun pudiera dar muchas si huolera gente y ánimos para empeñarse en sus labores. Se tie ne por cierto que de sola la gente de aquel mineral tocaba de cucrta. funeral cada año al Obispo 14,000 pescs. Fueron muy ricos sus mineros. Hubo uno que queriendo retirarse lleno de caudal, arrendó la incomparable mina, nombrada la Fragua, una de las 36 amojonadas de aquel paraje, en 1,040 pesos cada día. En estos tiempos aun se saca de estas minas no poca plata, lavándose a 10, 12, y 20 marcos por caión. Y si 
se desaguaran algunas de ellas dieran de 120 a 500 marcos. A más dee este mineral, hay otros muchos que se trabajan, y algunos de oro. Como también manantiales de aguas calientes y medicinales. Esta Provincia está situada a las orillas de la gran laguna de Titicaca, que también se llama de Chucuito. Le dan algunos de largo 36 leguas, desde la Villa de Puno hasta el Desaguadero, que realmente no son más que 31. Pero debiéndose contar desde Arapa y Achaya, pueblos de Azángaro, en donde tres ríos grandes forman un lago de ocho o nueve leguas, que se comunica por un estrecho en el sitio de Ramis con la gran laguna dándole 20 leguas desde Arapa hasta Puno en derechura, tiene dicha laguna 51 leguas de largo Noroeste-Sudeste. Por partes tiene 26 leguas, por otras menos porque es de figura irregular. En sus riberas hay pueblos de seis Provincias; Chucuito, Pacages, Omasuyos, Paucarcolla, Lampa y Azángaro. Su fondo es basiłnte para cualquier género de embarcaciones, pues en muchas ensenadas, no muy lejos de la orilla, hay cuatro y seis brazas de fondo y dentro de 40 y 50 , sin habérsele observado bajos. Críanse cerca de sus orillas unos yerbazales, que llaman Llachcs, que entran a comer las Vacas y los Cerdos y también mucha Totora 0 Enea, que en partes se eleva más de vara y niedia. De esta Totora hacen los Indios sus balsas, no sólo para pescar sino para navegar de unas partes a otras, y para pasar los ganados y frutos de sus cosechas de las muchas Islas que tiene la laguna a tierra. De las cuales están tan cercadas de Totora tupida, que es menester a fuerzalabrir faso para entrar en ellas. También hay en esta laguna sus Jormentas cyisusldesgracias;spor los vientos fuertes y turbulentos que alli corren. Sus aguas son gruesas, pero las beben los ganados y aun los Indios y todos los Uros. Esta es una casta de Indios, rústicos y pobres, que vivian antiguamente en las Islas con mucha desdicha. A fuerza de exhortación y con bastante trabajo han salido a tierra y se acomodan a vivir en unas tristes cuevas y en excavaciones, que cubren con esteras de Totoras y se ocupan en la pesca. Críanse en esta laguna varios pescados. Bagres, Omantos, Suches, Anchovetas, y Boquillas en abundancia. Estas últimas son, por lo común de cerca de un palmo y tres pulgadas de grueso. Los Indios de Yunguyo sacan cada año 700 o más arrobas, que llevan a vender a varios pueblos a cuatro o seis pesos el millar. También se hallan algunos Pejerreyes pequeños. Se cogen innumerables pájaros en la laguna, que salados son de saludable alimento. La Capital de esta Provincia es la Ciudad de Chucuito, donde reside el Gobernador. Está muy bien situada. Su altura de polo es de $17^{\circ}$. Goza de la vista de la la- 
guna y de muchas de sus Islas. A no habor tocio el año tanio frío en este País no hubiera otro de mús comodidades, ni lan alejre y divert:do en todo el Reino; pero el frío incomcda 10 bustante para no ser apetecido. Tiene esta Frovincia varios ríos, gue deseguan en la laguna. El maycr es el Ilave. Sus habianiss llegan a 30,000.

Comprende 18 Curatos. E! I en la Ciudad, es el de la Asunción. El Il en la rnisma, es el de Sunto [orringo. Hay también dos Hermitas: Santa Bárbara y San Sebastián. Es anexo del Curato de Sanio Domingo el Pueblo de Pichacani, asiento de Minas. El IIl es el asiento de San Antonio de Esquilache. El IV y V, San Pedro y San Juan, son del pueblo de Acore, con una Capilla, vice-parroquia. El VI y VII son del pueblo de llave: Santa Eárbura, con sis virs-parroguia, de la Purificación y San Miguel. El VIII, IX, X Y XI son de Juli, que los obtenian los Jesuitas, en donde habia Colegio. Sus Iglesias son San Pedro, Santa Cruz, La Asunción y San Juan Bautista, con un anexo que es el asiento de minas de Záacata, y otras dos Capillas, en dos Salinas que abastecen los minerales de esta Provincia. El XII, XIII, y XIV son de Pomata. Sus Iglesias son: Santicyo, de hermosa arquitectura San Miguel y San Martín. Hay en este Pueblo unc Hermita de Santa Bárbara y otra de Nuestra Señora del Rosario. El de Santiago tiene por anezo el asiento de Huacuilani. El XV y XVI son del pueblo de Yunguyo. Sus iglesias son de la Ásunción y la Magdalena. El XVII y XVIII son del pueblio de Zepita. Sus Iglesias son San Sebastián y San Pedro. El primero tiene por anezo el asiento o puebio del Desaguadero de esta Provineia.uccinelli Converso"

CATELOGO HISTORICO DE LOS VIRREYES, GOBERNALORES, PRESIDENTES, Y CAPITANES GENERALES DEL PERU, CON LOS SUCESOS MAS PRINCIPALES DE SUS TIEMPOS (31).

Reinando el Señor Don Carlos I. Rey de España, V Emperador de Alemania, se comenzó la conquista del Perú por Don Francisco Pizarro con el título de Adelantado mayor, y la gracia de Gobernador y Capitan General gozando de estos Empleos desde el año de 1530, a quien el Rey dió después el título de Marqués de los Atabillos. Murió en Lima a 26 de Junio de 1541. En su tiempo se fundó la Ciudad de San Miguel de Piura el ar̃o de 1531. La de Cartagena el de 1532. La de Guayaquíl el de 1532. Reventó el volcán de Cotopaxi el de 1533.

(31) El Conocimiento de los Tiempos. Año 1763, 25 pp. s.f. 
Se fundó la Ciuciad de Quito el de 1534. La de Lima el 18 de enero co 1535, y después la de Trujillo. La de Popayán el de 1537. Se dió la Balalia entre Pizarros y Almagros, quedando vencidos éstos a 6 de abril de 15.3\%. Fué hecha primera Catedral de estos Reinos la Igiesia de Santa Marta. Se exigió el Obispado de Cartagena. Tambión se erigió el Obispado del Cuzco en 1538, y fué éste mismo Obispo del Perú Don Fray Vicente Valverde, que murió el de 1524 en la Puná a manos de los Indios a quienes predicaba el Evangelio. Se fundó la Audiencia de Panamá en 1538. Se fundaron las Ciudades de Arequipa, La Plata y Huarmanga en 1539, y en este mismo año fué nombrado el primer Obispo de Quito y reventó el Cerro de Pichincha. Se fundó la Ciudad de Santiago de Chile en 14 de febrero de 1541.

2.--Reinando el mismo Monarca llegó al Perú el Licenciado Cristóval Vaca de Castro del Consejo Feal de Castilla, en medio de alionotos del Reino el año de 1541. Gobernó hasta el de 1544 y volvió a España. En su tiempo fué asolada Guatemala por un formidable terremoto, a los 14 años de su fundación en 11 de setiembre de 1541 . Se extinguló el kando de los Almagros en la Batalla de Chupas, juiro a Huamanga, en 6 de Setiembre de 1542. Se fundó por el mismo mes y año la Ciudad de Huánuco. Se electuó la erección del Obispado de Lima, siendo su primer Obispo Don Fray Jerónimo de Loayza, en 25 de julio de 1543 .

3.- Reinando el mismo Monarca entró a Lima, a 15 de Mayo de 1544, Elasco Núñez Vela, que fue el primero que tuvo título de Virrey y de Presidente de lareal Audiencia, Gue serestableció a su llegada. Murió en 15 de enero de 1546, en la Batalla que le dió Gonzalo Pizarro en Iñaquito. Había sido preso por la Real Audiencia para que se volviese a España en 23 de Septiembre de 1544. En su último se volvió a alborctar el Reino. Unos Corsarios franceses saquearon a Santa Marta y Cartagena en 1544. Se descubrió el Cerro Potosí en 1545. Fué preciscada la Audiencia a nombrar par Gobernador del Reino a Gcazalo Pizarro, en 30 de Octubre de 1544. Se fundó la Ciudad de Loja en 1546.

4.--Reinando el mismo Monarca llegó a Panamá, a 10 de Septiembre de 1546, el Licenciado Pedro de la Gasca, del Consejo de la Suprema y General Inquisición, con el título de Presidente, Gobernador y Capitán General, al tiempo de las nuevas alteraciones del Reino yue pacificó. El de 1550, dejando el Gobierno a la Real Audjencia, volvió a España, donde obtuvo las Mitras de Palencia y Siguenza. En su tiempo se erigió el Obispado de Popayán en 1547. Se extinguió el pariido 
de Gonza!o Pizarro el nueve de abril de 1548. Se electuo la erección del Arzobispajo de Lima, recibienjo el Palio el Señor Loayza a nueve de Septiembre de 1548. Se fundj la Ciudad de la Paz en el año de 1549. Se establezió en Santa Fé lo Real Audiencic en 15.34. Se iestablecio !s Real Aujiencia de Lina en 1550. Se erigió el juzgado de Bienes de Difuntos y se fundó la Ciudad de la Concepción de Chile.

5.- Peinando el mismo Monarca entro en Lima el Virrey Don Antonio ce Mendoza, Virrey je la Nueva España en 23 de setiembre de 1551. Murió „n Lima el 21 de julio de 15.52. Quiedó Gobernando la Rea! Audiencia. En su ilempo se erigió el Obispato de la Plata. Se estableció la Guardia de Alabarderos. Continuaba el nismo Arzobispo. En el de 1552 se tundj la Ciudad Imperial y la de Vaidivia y se celobró un Concilio o Congregación en Lima. En 1553 se fundó la Real Universidad de Sen Marcos (.3.).

6.--Reinando el mismo Monarca enirć a Lima el Virrey Don Andrés Hurtado de Mendoza, Marques de Cañete, en 6 de julio de 1555. Murij en Lima a principios do 1561 , pocos dias antes que entrase en Lima su sucesor. En su tiempo hizc la renuncia el Señor Carlos V., en 25 de octubre de 1555, y fué proclamado en Lima el Señor Don Fe lipe II en 1556 .

Se iundó la ciudad de Cuenca on 1557. Se instituyó la Compañía de Lanzas de a Caballo y otra de Intantería, con 200 Arcabuzeros con sueldo, que se extinguió diespués. Murio el Señor Carlos V. en 21 de Septiembre de 1558.

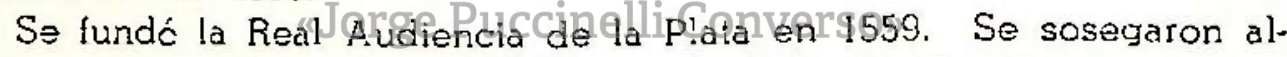
gunas nuevas alteraciones del Reino. Se trajo de España, y se plantó en el Perú, el primer Olivo en 1560. Salió de Vilcabamba el Prizcipe Sayri-Tupac Inca y se bautizó. Continuaba el mismo Arzobispo.

7.-Reinando ei Señor Don Felipe II entró en Lima el Virrey Don Diego Ĺ́pez de Zúñiga y Velasco Conde de Nieva, a 13 de abril de 1561. Murió en Lima al año siguiente. Quedó gobernando la Real Audiencia, en cuyo tiempo se erigieron ios Obispados de Santiago y de la Imperial de Chile. Se fundó la Real Audiencia de Quito en 1563. $Y$ se fundó de crden de este Virrey la Ciudad de lca en el mismo año. Continuaba el mismo A.rzobispo.

8.-Reinando el mismo Monorca entró en Lịma el Licenciado Loce García de Castro del Consejo Real de Indias, con título de Presidente,

(32) Se inauguró el día dos de enero de 1553. La fundación dala del 12 de mayo do 155], según el texto de la Real Cédula dada en Valladolid. 
Gobernador y Capitán General, en 22 de setiembre de 1564. Gobernó hasta el 26 de noviembre de 1569, y volvió a España. En su tiempo se erigió el Arzobispado de Santa Fé en 1564, y se descubrió la mina deAzogue de Huancavelica. Se fundó la Casa de Moneda en Lima en 1565, y hubo en Guatemaia un fuerte terremoto. Reventó furioscamente el volcón de Pichincha en 17 de cclubre de 1566. Se c-3:ebró el Concilio Provincial en Lima en 1567. Se erigió la Real Sala del Crimen en 1568 y hubo un gran temblor en Lima. Continuaba el mismo Arzobispo.

9.- Reinando el mismo Mcnarca entró en Lima el Virrey Don Francisco Toledo en 26 de Noviembre de 1569. Acabó su gobierno en 23 de setiembre de 1581 y volvió a España. En su tiempo se fundó el Tribunal del Santo Oficia de la Inquisición en 1570 y hubo un terremoto en Chile, en que se trastornaron algunos Cerros y se asolaron lugares enteros. Se erigió el Obispado de Tucumán en 1571. Se pasó la Casa de Moneda de Lima a Potosí en 1572. Se erigió el Tribunal de la Santa Cruzada en 1574. Murió el Arzobispo Loayza a cinco de octubre de 1575. Se trasladó la Real Universidad de San Marcos al sitio en que hoi está (33), en 1576. Fué electo de Arzobispo de Lima Don Diego Gómez de la Maàrid en 27 de marzo de 1577, que no paso a Lima y murió de Obispo de Badajóz en 15 de Agosto de 1601 . Hubo un gran terremoto en Giatemalà èn 30 de noviembre de 1577. Reventó el Vo!cán de Pichincha en 1577 . Hubo un fuerte terremoto en Lima en 17 de julio de 1578. Fue degollad6 Tupac Amaru Ineà con desaprobación del Rey. Se hicieron las Ordenanzas del Perú, después de la visita de todo el Fieino. Entró en el Mar del Sur el primer pirata inglés Francisco Drake en 1578. Se publicaron las Constituciones de la Real Universidad de San Marcos en 1581 (34). Entró en Lima de Arzobispo e! Glorioso Santo Toribio a 24 de mayo de 1581.

10.- Reinando el mismo Monarca entró en Lima el Virrey Don Martín Henrríquez, Marqués de Alcañices, Virrey de la Nueva España, en

(33) De San Marcelo a la plaza de la Inquisición. (En la segunda mitad del siglo XIX se trasladó al local del Convictorio de San Carlos, donde aun permanece).

v. El actual Edificio de la Universidad de Marcos por Daniel Valcárcel y Gred Ibscher. Imp. Torres-A.guirre, Lima, 1951.

(34) Don Antonio Ricardo las imprimió en Lima el año de 1602, siendo por lo tanto un incunable limeño.

Cronológicamente, la Universidad colonial tuvo las Constituciones de 1571, 1578, 1581, 1584, las Constituciones añadidas de 1624, lo ordenado en la Recopilación de 1680 (L:bro I, Título XXII), las Modernas de 1735 y los Reglamentos de 1771 y de 1816. 
23 de Septiembre de 1581. Murió en Lima en 15 de Marzo de 1583, y quedó Gobernando la Real Audiencia. En su tiempo se fundó el Colegio de San Martín. El día 15 de Agosto de 1582 empezó el tercer Concilio Provincial de Lima, que se constituyó por Octubre de 1583 y fué aprobado por el Rey y por el Papa. Se fundaron dos poblaciones en el Estrecho de Magallanes para su defensa: Philipopolis y Nombre de Dios, en 1582, que no tuvieron permanencia. Hubo un fuerte temblor en Arequipa y otro formidable en Chile, en 1582. Después saqueó Francisco Drake a Cartagena, quemando la mitad de la población en 1585. Nació Santa Rosa en 20 de abril de 1586, en el cual hubo un fuerte temblor de Lima el día de la Octava de la Vistación de Nuestra Señora. Continuaba el mismo Santo Arzobispo.

11.-Reinando el mismo Monusca entró en Lima el Virrey Don Fer nando de Torres y Poriugal Conde del Villar Don Pardo, en 30 de noviembre de 1586. Déó el goblerno en 8 de enero de 1530 y vol. vió a España. En su tiempo hubo un tormidable temblor en Guatemala en 23 de Diciembre de 1586, y por seis meses antes arrojaba uno de los Volcanes un río de fuego. Entró en el Mar del Sur el Pirata inglés Thomas Cavendish, que tomó la Nao de China en 1587, y hubo un fuerte terremoto en Quito. Continuaba el mismo Sänto Arzobispo.

12.--Reinando el mismo Monarca entró en Lima el Virrey Don García Hurtado de Mendoza Marquśs de Cañetes en 8 de enero de 1590. Había sido Gobernador de Chile en tiempo de su padre. Go. bernó el Perú hasta "eP 24 de Jufio de 1596 Yyevoivió a España. En su tiempo salieron tres navios a reconocer las Yslas de Salomón con ánimo de poblarlas en 1590, y se demarcaron. Se celebró Concilio Provincial en Lima, en 1591, y se fundó por el Santo Arzobispo el Colegio Seminario. Entró on el Mar del Sur el Pirata inglés Ricardo Hawkins, que fué hecho prisionero en 1594. Se estableció el derecho de las Alcabalas en 1596. Sucedió el prodigio de sudar copiosamente una imagen de Nuestra Señora de Copacabana y del Niño en Lima. Continuaba el mismo santo Arzobispo.

13.-Reinando el mismo Monarca entró en Lima el Virrey Don Luis de Velasco Marqués de Salinas, Virrey de la Nueva España, en 24 de Julio de 1596. Duró su gobierno hasta 18 de enero de 1604, y volvió al Virreynato de México. En su tiempo murió el Señor Don Felipe II, en 13 de Septtiembre de 1598. Se levantaron los Araucanos, en 24 de noviembre de 1599, y arruinaron seis Ciudades. Se numeraron los habitantes de Lima, y se hallaron 14,262 en el año de 1600 . Infestó estos Mares el Pirata Olivier de Nort en el mismo año, y reventó con 
gránde estrago el Volcán de Arequipa el día 18 de febrero. Se celebró Concilio Provincial en Lima en 1601. Continuaba el mismo Santo Arzobispo.

14.-Reinando el Sr. Don Felipe III entró en Lima el Virrey Don Gaspàr de Zúñiga y Acevedo Conde de Monterrey, Virrey de la Nueva Éspiña, en 18 de enero de 1604. Murió en 16 de Marzo de 1606. Quedó Gobernando la Real Audiencia. En su tiempo hubo un fuerte temblor en Arequipa, en 2 de noviembre de 1604. Se estableció en Lima el Tribunal Mayor de Suentas en 1605, y se erigió el Obispado de Santa Cruz do la Sierra. Murió en Saña el Arzobispo Santo Toribio, a 23 de Marzo de 1606, precediendo un fuerte Terremoto. I

15.--Reinando el mismo Monarca entró en Lima el Virrey Don Juan de Mendoza y Luna Marqués de Montes Claros, Virrey de la Nueva España, en 21 de Diciembre de 1607. Duró su gobierno hasta 18 de Diciembre de 1615, y volvió a España. En su tiempo se estableció el Tribuna! del Consulado en Lima y se erigió el Arzobispado de la Plata en 1608. Se erigió la Real Audiencia de Chile en Santiago en 1609. Se erigieron los Obispados de Huamanga, Arequipa y la $\mathrm{Paz}$ en el mismo año, y hubo un fuerte temblor en Lima. Entró el Arzobispo Don Bartolomé Lobo Guerrero en 4 de Octubre de dicho año de 1609. Se impliso el derecho de la Sisa. Se fundó el Tribunal del Santo Oficio de Cártagena en 1610. Murió San Francisco Solano en 14 de julio de 1610. En este año se acabó el Puinnte de Lima, y la Alameda en 1611. En 1614 se numeraron losahabitantest de Lima y se hallaron 25,454. Entró en el Margel del Surnell Pirata inglés, Jorge Spitberg on 1615.

16.--Reinando el mismo Monarca entró en Lima el Virrey Don Francisco de Borja y Aragón Príncipe de Esquilache, a 18 de Diciembre de 1615. Se embarcó para España el día 31 de Diciembre de 1621 sin esperar sucesor, dejando el Gobierno a la Real Audiencia. En su tiempo entraron en el Mar del Sur Jacobo Lemaire y Guillermo Schouten en 1616, y se erigieron los Obispados de Trujillo, de la Concepción y de Buenos Ayres. El mismo año entró por el estrecho al Mar del Sur el Pirata inglés Guillermo Fzten. Murió Santa Rosa en 24 de agosto de 1617. Se fundó la Casa de Moneda de Santa Fé. Sucedió el gran terremoto que asoló las Ciudades de Trujillo y Piura en 14 de febrero de 1619. Murió Don Felipe III en 31 de Marzo de 1621. Murió el Arzobispo Lobo Guerrero en 8 de enero de 1622.

17.-Reirando el Señor Don Felipe IV entró en Lima el Virrey Don Diego Fernández de Córdcva Marqués de Guadalcázar, Virrey de la Nue- 
va España en 25 de julio de 1622. Gobernó hasta el l4 do enero de 1629 , y volvió a España. En su tiempo se puso en ia punta de la Is. la de Son Lorenzo del Callao el Pirata Olandes Jacobo L'Heremite con 11 nàvíos con más de 1,600 hombres de desemberco y murió allí de despecho por no no poder conseguir su intento, en 2 de junio de 1624 . Entrć er Lima el Arzobispo Don Gonzalo de Ocampo a 20 de abril de 1625, y murió en la Visita en 19 de Diciemore de 1626, electo Arzobispo de Sevilla.

18.-Reinando el mismo Monarca entró en Lima el Virrey Don Jerónimo Fernández de Cabrera Eobadilla y Mendoza Conde del Chinchón, de los Consejos de Estado y Guerra en 14 de enero de 1629 . Goberró hasta el 18 de Diciembre de 1639 y volvió a España. En su tiempo entró en Lima el Arzobispo Don Fernando Arias de Ugarte en 14 de febrero de 1630 . Hubo un formidable temblor en Lima estando en encierro de Toros, a 27 de noviembre del mismo año, en que sucedió el prcdigio de haberse vuelto una imagen de Nuestra Señora colocada sobre el pórtico de la Iglasia de San Francisco como con afecto de mirar al Sagrario. Se descubrio el grande específicc de la Cascarilla de loja. Murió el Arzobispo Ariús de Ugarte en 27 de enero de 1638.

19.--Reinando el mismo Monarca entró en Lima el Virrey Don Pedro de Toledo y Leyva Marquós de Mancera, del Consejo de Guerra, en 18 de diciembre de 1639 . Gobernó hasta el 20 de Septiembre de 1648, y volvió a España. En su tiempo entró en Lima el Arzobispo Don Fedro Villagómez, reje 22 de MayoCag 16490 "Se amuralló y fortificó el Callao con Artillería de Bronce fundido en Lima, y asimismo les Puertos de Valdivia y Valparaíso por haber intentado, con una Escuadra Holandesa, Enrrique Breaut fundar colonia en Valdivia, de donde fué rechazado. Se introdujo el papel Sellado en 1641. Hubo en Quito repetidos temblores en los meses de febrero y Marzo de 1615, y por Abril del mismo año se asoló Riobamba con uno formidable. Hubo un terremoto casi universal en el Perú que arrasó a Santiago de Chile en 13 de mayo de 1617.

20.-Reinando el mismo Monarca entró en Lima el Virsey 'Don García Sarmiento de Soto Mayor Conde de Salvatierra, Virrey de la Nueva España, en 20 de Septiembre de 1648. Gobernó hasta 24 de tebrero de 1655. y murió después en Lima a 26 de junio de 1659. En su tiempo se vió el repetido prodigio de un Niño aparecido en la Custodia en el Pueblo de Eten, el día 2 y 21 de julio de 1649. Hubo un for- 
midable terremoto en el Cuzco en 31 de Marzo de 1650. Se fabricó la Pila de la Plaza de Lima. Continuaba el Mismo Arzobispo.

21.--Reinando el mismo Monarca entró en Lima el Virrey Don Luis Henrríquez de Guzmín Concie de Alva de Liste, Virrey de la Nueva España, y el primer Grande de España que pasó al Perú, en 24 de febrero de 1655. Gobernó hasta 31 de julio de 1661 y volvió a España. En su tiempo hubo un temblor en Lima espantoso, a 13 de noviembre de 1655. Tomaron los Ingleses a Jamaica en 1655. Hubo un temblor fuerte en Chile, que duró un cuarto de hora, en 15 de Marzo de 1657. Reventó el volzán de Pichincha, a 12 de Octubre de 1660. Continuaba el mismo Arzobispo.

22.--Reinando el mismo Monarca entró en Lima el Virrey Don Diego de Benavides y de la Cueva Conde de Santistevan, del Consejo de Guerra, Virrey de Navarra, en 31 de julio de 166l. Murió en Lima en 16 de mayo de 1666. Quedó Gobernando la Real Audiencia. En su tiempo se fundó Real Audiencia en Buenos Ayres, en 1663, que no tuvo permanencia. Hubo un levantamiento en la Provincia de Chuquiabo, que se disipó brevemente, y hubo un fuerte temblor en Ica en 12 de Mayo de 1664. Murió el Señor Don Felipe IV en 17 de Septiembre de 1665. Continuaba el mismo Arzobispo.

23.--Reinando el Señor Don Carlos II entró en Lima el Virrey Don Pedro Fernández de Castro y Andrade Conde de Lemos, Grande de España, en 21 de noviembre de 1667. Murió en Lima en seis de Diciembre de 1672. Quedó Gobernando la Real Audiencia. En su tiempo sucedieron los últimos alborotos dec Puno,liy Selagublósla"rica mina de Salcedo en 1669. Tomó y quemó Morgan a Panamá en 1670; y el mismo año entró en el Mar del Sur el Pirata inglés Carlos Enrique Clerk, que fué preso en Valdivia. Murió el Arzobispo Villagómez en 12 de mayo de 1671, y entró en su lugar Don Fray Juan de Almoguera en 6 de mayo de 1674.

24.--Reinando el mismo Monarca entró el Lima el Virrey Don Baltasar de la Cueva Henrríquez de Saavedra de Castellar, del Consejo y Cámara de Indias, en 15 de Agosto de 1674. Gobernó hasta 7 de Julio de 1678. y volv:ó a Éspaña. En su tiempo murió el Arrobispo Almcguera en 12 de Marzo de 1676, y entró en su lugar Don Melchor de Liñán $Y$ Cisneros en 14 de febrero del678. Hubo un fuerte terremoto en Lima a 17 de Junio de 1678.

25.-Reinando el mismo Monarca fué recibiào en Lima por Virrey Don Melchor de Liñán y Cisneros, su Arzobispo, en 7 de Julio de 1678. Gobernó hasta 20 de noviembre de 1681. Continuó después 
en la dignidad de Arzobispo y le concediól el Rey una Merced de Título de Castilla, de Conde de la Puebla de los Valles, que se verificó en su Hermano. En su tiempo hubo un fuerte temblor en Guatemala por Marzo de 1679. Entraron en el Mar del Sur por el Darién los Piratas ingleses Juan Guarín y Bartolomé Sharp en 1680; y en este mismo año, a 7 de Agosto, fueron desalojados la primera vez los Portugueses de la Colonia del Sacramento, que volvieron a ocupar después.

26. -Reinando el mismo Monarca entró en Lima el Virrey Don Melchor de Navarra y Rocaful Duque de la Palata, Príncipe de Massa, de los Consejos de Estado y Guerra, en 20 de noviembre de 1681. Gobernó hasta 15 de Agosto de 1689. Murió en Portobslo, volviendo a España, en 13 de Abril de 1691. En su tiempo hubo un fuerte temblor en Arequipa en 1682, y el mismo año se estableció nuevamente Casa de Moreda en Lima. Entró en el Mar del Sur el Pirata inglés Eduardo David por el Cabo de Hornos, y otros ingleses y franceses por el Darién en 1685, que junto con 10 embarcaciones talaron toda la Costa, saqueando a Sãña, Casma, Huaura, Santa, Pisco y Guayaquil. Se fabricó la Muralla de Lima. Sucedió un gran terremoto en Lima en 20 de Octubre de 1687, precedido del prodigio observado en una imagen de Nuestra Señora, de dejar ver cubierto su rostro de sudor y lágrimas. Hubo antes otros dos temblores fuertes en 28 de enero y 31 de marzo del mismo año, y otro a 10 de octubre de 1688. En 12 de febrero de 1689 hubo un fuerte temblor en Guatemala. Goñtinuaba el mismo Arzobispo.

27.-Reinando el mismo monarca entró en Lima el Virrey Don Me!chor Portocarrero Laso de la Vega Conde de "SP" Monclova, Grande de España, Virrey de la Nueva España, en 15 de Agosto de 1689. Murló en Lima en 22 de Septiembre de 1705. Quedó Gobernando la Real Audiencia. En su tiempo se reparó la Iglesia Catedral. Se reedificó el Palacio y se hicieron los Portales de la Plaza y Casas de Cabildo, como asimismo se reparó toda la Ciudad de los estragos causados el año de 1687. Hubo en Lima un fuerte temblor, a 21 de noviembre de 1694. Se fabricó un hermoso Muelle en el Callao. Tomaron los franceses a Cartagena en 1697. Este mismo año hubo en Lima un temblor fuerte en 29 de Septiembre, y otro semejante el día 14 de Julio de 1699. El 20 de Junio de 1698 se arruinó Latacunga con un fuerte terremoto. Se fabricaron tres navías de Guerra en Guayaquil para defensa del Reino. Se numeraron los habitantes de Lima en 1700 y se hallaron 37,234 . Murió el Señor Don Carlos II a lo de Noviembre de 1700. Fué proclamado en Lima el Sr. Don Felipe V, a 5 de Octubre de 1701. Comensaron a entrar en el Mar del Sur Navíos franceses comerciantes. En 
14 de Marzo de 1705 fueron desalojados segunda vez los Portugueses de la Colonia del Sacramento, que después de poco tiempo volvieron à scupar. Continuaba el mismo Arzobispo.

28.-Reinando el Sr. Don Felipe V, entró en Lima el Virrey Don Manuel Oms de Santa Pau Oilim de Semanat y de la Nuza Marqués de Céstel dos Rius, Grande de España, y Embajador en Lisboa y París, el día 7 de Julio de 17.07, y murió en Lima en 22 de Abril de 1710. En su tiempo murió el Arzobispo Liñán en 28 de Junio de 1708. Entraron ai Mar del Sur los Piratas injleses Dampierre y Roggers en 1709, que saquearon a Guayaquil. En este mismo año fué electo Arzobispo de Lima Don Pedro Francisco Levanto, quien por haberlo aprisionado los Ingleses al salir de España, renunció y fué promovido al Obispado de Badajoz el año de 17il. Proseguía el comercio de los Franceess.

29.-Reinando el mismo Monarca entró en Lima Don Diego Ladrón de Guevara, Obispo de Quito, en 30 de Ágosto de 1710, quien por pliego de Providencia estaba nombrado en lercer lugar para este Virreynato, y habían muerto los dos primeros que eran los Obispos de Cuzco y Arequipa. Gobernó hasta dos de Marzo de 1716. Y habiendo obtenido licencia para pasar a España, murió en Mexico a nueve de noviembre de 1718. En su tiempo entró en Lima el Arzobispo Don Antonio Soloaga, en 21 de mayo de 1714. Entraron dos Piratas Ingleses al Mar del Sur en 1715, de qué se apresó uno en las costas del Perú y otro en las de la Nueva España. Hubo un formidable terremoto en Moquegua en 22 de Agóstorde 1715, y otro fuerte en Lima en 6 de febrero de 1716.

30.-Reinando el mismo Monarca entró interinamente en Lima el Virrey Don Fray Diego Morcillo Rubio de Auñón, Arzobispo de la Plata, en 15 de Agosto de 1716 y volvió a su Arzobispado habiendo gobernado sólo 50 días. Continuaba el mismo Arrzobispo.

3i.--Reinando el mismo Monarca entró en Lima el Virrey Don Carmine Nicolás Caraciolo Príncipe de Santo Buono, Grande de España, en cinco de octubre de 1716. Gobernó hasta 26 de enero de 1720 , y volvió a España. En su tiempo hubo un formidable temblor en Guatemala eir 29 de Septtiembre de 1717, arrojando mes y medio antes mucho fuegc el Volcán. En este mismo año vino de España una Escuadra de tres navíos a desalojar a los Franceses comerciantes en el Mar del Sur. Se erigió en Virreinato el Nuevo Reino de Granada, extinguiéndose las Audiencias de Panamá y Quito, en 1718, siendo su primer Virrey el Teniente General Don Jorge de Villalonga Conde de la Cueva, General del Callao, cuya dignidad solo duró hasta el año de 1722 y 
se volviæron a habilitar dichas Audienciās. Comenzó una Peste en las Provincias interiores del Perú en 1719, que duró tres años, en que murieron innumerables Indios y al mismo tiempo hubo ial carestía que se llegó a comprar la hanega de trigo en 50 pesos. Hubo un fuerte temblor er: Huamanga en 17 de Junio de 1719. Continuaba el mismo Arzobispo.

32.--Reinando el mismo Monarca entró en Lirna el Virrey Don Fray Diego Morcillo Rubio de Auñón, Arzobispo de la Plata, en 20 de ene-. ro de i720. Dejó el mando en 14 de Mayo de 1724, y por muerte del Arzobispo Soloaga, sucedicia en 22 de entro de 1722, fué provisto al Arzobispado de Lima en 18 de Diciembre de 1723. En su tiempo entró al Mar del Sur el Pirata Ingí́s Juan C:iperión en 1720, que apresó al Mărqués de Villarrocha con su mujer y familia, que pasaba de Panamá al Perú en un Navio, y a la Condesa de las Lásunas, que en otro se conducía del Callao a Guayaquil. Hubo un fuerie temblor en Chile en 24 de Mayo de 1722. Declararon la Guerra los Araucanos en 9 de Marzo de 1723. Hizo la renuncia el Sr. Don Felipe V, en 15 de ensro de 1724.

33.--Reinando el Sr. Don Luis I entró en Lima el Virrey Don Josź Aimendáriz Marqués de Castelfuerie, Capitán General de los Reales Ejércitos y Caballero del insigne Orden del Toison, en 14 de Mayo de 1724. Gobemó hỉstai cutatro dedeneronden 736، y volvió a España. En su tiempo murió el. Sr. Don Luis I en 31 de Agosto de 1724, y antes de llegar al Perú la noticia de su muerte fués proclamado en Lima en tres de Diciembre del mismo año, y al mismo tiempo hicieron las paces los Araucanos. Hubs en Lima un fuerte terremoto en 6 de enero de 1725, otro igual en Arequipa el día is del mismo mes, y en Chile otro semejante en 27 de Marzo del mismo año. Entraron tres Navios Holandeses al Mar del Sur en 1727, de que se apresaron dos en sus costas y el otro en las Molucas. Murió el Arzobispo Morcillo, en 11 de Marzo de 1730. Hubo en Chile un espantoso terremoto, en que se inundó la Concepción, en 8 de julio de 1730. Se fabricó una fragata de Guerra en Guayaquil, nombrada San Fermín. Sucedieron las Revoluciones del Paraguay, que ocasionaron la inuerte de un Ministro de la Real Audiencia de la Plata, y accidentalmente de dos Religiosos de San Francisco en la Plaza de lima en 5 de Julio de 1731. Se recibió en Lima al Arzobispo Don Francisco Antonio Escandón, en 23 de febrero de 1732. Subió un armamento de Portugueses por el Marañón con el designio de establecerse en los dominios de España, cuyo intento se remedió en 1732. Hubo en Lima un fuerte temblor en 2 
de Diciembre del mismo año, y otro semejante en 28 de mayo de 1734. Entró en el Mar del Sur un Navío Holandés mercante, que no pudiendo vender la carga en sus Costas pasó a las Molucas en 1735.

34.--Reinando el Sr. Don Felipe V, entró en Lima el Virrey Don Antonio José de Mendoza Camaño y Sotomayor Marqués de Villa-García, Conde de Barrantes, en 4 de enero de 1736. Gobernó hasta el 12 de Julio de 1745. Al volver a España el de 1746 murió en 15 de Diciembre en la alturã de 33, habiendo pasado el Cabo de Hornos. En su tiempo se hizo la célebre medida de los grados cerca del Ecuador en la Provincia de Quito. Se

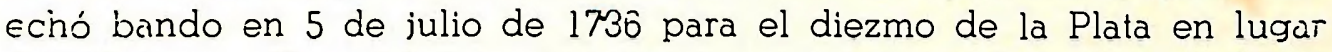
del Quinto. Sucedió la primera quema de Panamá la noche del 2 de febrero de 1737. Hubo un gran terremoto en Valdivia en 24 de dicjembre de 1737, que la asoló. Se puso una estatua Ecuestre del Sr. Don Felipe V sobre el Arco del puente de Lima en 1738, que con el mismo arco padeció ruina en el terremoto del año de 1746. Murió el Arzubispo Escandón en 28 de abril de 1739. Fué arruinado Portobelo por una Escuadra Inglesa comandada pór el Vice-Almirante Vernón en 13 de Marzo de 1740, y después el Castillo de Chagres. Pasó el ViceAlmirante Anson al Mar del Sur y quemó a Paita en 24 de Noviembre de 1741, después de haber hecho varias presas. Este mismo año sə estableció, con el motivo de la Guerra, un nuevo impuesto en el Perú. Sitiaron los Ingleses a Cărtagena este mismo año con un armamento de 50 Navíos de Guerra y 13 embarcaciones de iransporte, con 13,000 hombres de desembarcó, que no fudieron tomar por la conducta y esfuerzc de Don Sebastián de Eslava, Capitán General de los Reales Elárcitos y Virrey del Nuevo Reino desde marzo de 1740, en que se volvió a erigir a aquel Virreinato y nombrado para el del Perú en noviembre de 1742, a donde no pasó. Reventó el Volcán de Cotopaxi en 23 de junio y en 9 de noviembre de 1742. Hubo una sublevación de los Indios Chunchos, cuyos Pueblos cran de moderna conversión, en la Provincia de Jauja a mitad del año de 1742, levantando un Rey y retirándose a las Montañas de la Andes, desde donde hicieron varias salidas a las Provincias inmediatas, llegando a tener un Exército de 3,000 hombres y en una de ellas llegaron hasta la de Canta 40 leguas de Lima (35). Entró en Lima el Arzobispo Don José Antonio de Cevallos el Caballero, en 10 de Septiembre de 1742. Rebentó con horrible estrago el Vol-

(j5) Véase la nota No 21. 
cán de Cotopaxi en 30 de Diciembre de 1744. Murió el Arzobispo Cevallos en 16 de enero de 174:5.

35.-Reinando el mismo Monarca entró en Lima el Virrey Don José Manso de Veiasco Conde de Superunda, Teniente Gerreral de los Reales Ejercitos y Presidente de Chile, en 12 de julio de 1745. Gobarnó hasta 12 de octubre de 1761, y salió para España el día 27 del mismo mes. En su tiempo fué promovido al Arzobispado de Lins, a 14 de junio de 1746, de que tomó posesión por poder Don Agustín Rodríguez Delgado, que murió viniendo de la Plata de donde era Arzobispo, en 18 de diciembre del mismo año. Murić el Sr. Don Felipe V, en 9 de julio de 1746. Sucedió el gran terremolo de 28 de octubre de 1746 en que se arruinó Lima y al mismo tiempo se inundó y asoló el Callao. Fué proclamado en Lima el Sr. Don Fernando VI, en 23 de Septiembre de 1747. Se fundó a un cuarto de legua do! Callao destruído, el Pueblo de Bellavista el mismo año. Se fabricó el Fuerte de San Fernarido del Callao. Se reedificó el Palacio en 1748. Hubo un levantamiento de Indios en la Provincia de Huarochipl, junto con una Conspiración do muchos Indios de Lima y de otras Provincias, que descubierta a tiem. po se disipó, castigando a los principales motores y cabezas en Lima en 1750, y por medio de tropa reglada se hizo lo mismo en dicha Provincia. Se pobló la Isla Grande Juán Fernándoz =l mismo año. Entró a Lima el Arzobispo Don Pedro Antonio Barroeta y Angel en 26 de Ju nio de 1751 .

Se quitó el nuevo impuesto del tiempo de su antecesor en 1751. Se fabricó la Casa de Moneda, que se acabo en 1753, pero desde el de 51 se empezó a fabricar la Moneda circular. Cesó el privilegio de ser presentados los Regulares a Beneficios Curados en 1751. Hubo un terremoto en Chile, en que se inundó y arruinó la Concepción en 25 de Mayo del mismo año y en éste mismo se extinguió la Audiencia de Panamá. Se reedificó el Arco del Puente en 1752. Tomó una nueva forma el Tribunal de Cruzada el mismo año, y se estableció el Estanco del Tabaco de polvo y el siguiente el de Rama. Se construyó en Guayaquil un Navío de Guerra de 60 cañones. Se trató de la nueva línea divisoria de las tierras de Portugal y España en la América por Comisarios, enviados a este fin en 1752, que úitimamente no tuvo efecto. Se permitió repartimiento a los Corregidores, arreglándose al arancel y $\mathrm{Ta}$ rifa, que se señaló en cada Provincia en 1753. Se reedificó la Iglesia Catedral, cuya mifad se estrenó en 30 de Mayo de 1755 y se concluyó el resto para ocho de Diciembre de 1758. Asimismo se reedificó en su tiempo casi toda la Ciudad con Templos y Hospitales. Se extinguió 
casi del todo la rebelión de Indios de las Montañas. Se averiguaron los habitantes de Lima y se hallaron cerca de 54,000 en 1755. Este año hubo un fuerte temblor en Quito el 28 de Abril, y otro formidable el día 3 de Mayo. Sucedió la segonda quema de Panamá en 31 de Marzo de 1756. Se reedificaron las fortalezas de Portobelo. Hubo un formidable iemblor en Latacunga, a 22 de Febrero de 1757, que la arru:nó. Fué promovido al Arzobispo Barroeta al Arzobispado de Granada en 1758. Murió el Sr. Don Fernando VI en 10 de Agosto de 1759. Hubo un temblor formidable que arruinó a Trujillo en 2 de Septiembre del mismo año, y en este mismo entró en Lima el Arzobispo Don Diego de Ccrro en 27 de Noviembre. Fué proclamado en Lima el Sr. Don Carlos IIl (que Dios guarde) en 21 de Agosto de 1760. Murió el Arzobispo Corro en Jauja en 28 de Enero de 1761.

ac.-Reinando el Sr. Don Carlos III (que Dios guarde) llegó al Callào el Exmo. Señor Don Manuel de Amatt y Juniet, Caballero del Orden de San Juan, Teniente General de los Reales Ejércitos, Presidente de Cinile, que al presente gobierna/gloriosamente estos Reinos, en 12 de Ostubre de 1761. Hizo su entrada pública en Lima a 2.1 de Diciembre del mismo año (36).

\section{Biblioteca de Tetras}

Este año, en lugar de la introducción a la Epheméride, va otra á la p£queña obra, que la sigue. Las noticias, que he adquirido del Reyno del Ferú por medio de algunas relaciones, hechas por los Corregidores, en sus Provincias, me han dado motivo para empezar una descripción de este Reyno. La esperanza de adquirir las restantes, me hacen prometer su continuación. Bien veo la dificultad de la promesa, y

(36) Después de Amat, gobernaron los siguientes Virreyes: Don Manuel de Guirior (1776VII-1; a 1780-VII-20), Don Agustín de Jáuregui (1780-VII-20 a 1784-IV3); Don Teodoro de Croix (1784-IV-3 a 1790-111-25), Don Francisco Gil de Taboada y Lemus (1790Ill-25 a 1796-VI-6), Don Ambrosio O'Higgins 1796-VI-6 a 1801-111-18), Don Gabriel de Avilés (1801-XI-6 a 1806-VII-26), Don José Fernando de Abascal (1806-VII-26 a 1816VII-7), Don Joaquín de la Pezuela (1816-VII-7 a 1821-1-29) y Don José de la Sema (1821-1-29 a 1824-XII-9).- (D. V.).

(37) Conocimiento de los Tiempos. Año 1764. 4pp. iniciales s-f. (v. nota 6). 
la arduidad de el Empeñc. Es muy vasto el campo, que pretendo medir y no muy proporcionados los medios. No todas las relaciones de las Provincias estan hechas con la exactitud, que le necesita; porque no todos los que las han hecho tienen la instruccion, que basta para ello. Esto ha sucedido siempre. En tiempo del Duque de la Palata se pidio relacion de cada Provincia á sus respectivos Corregidores. Entregaronse al Doctor Don Juan Ramon, Catedratico de Prima de Matemáticas; el qual no pudo desenredarse de las contradicciones, que, en materia de Geográlía, halló en ellas; y así nada se hizo. Para no verme en el mismo conflicto, he procurado consultar muchos sugetos por lo respectivo á cada Provincia, á fin de adquirir mas noticias, ó verificar las ya adquiridas. De este modo espero expedirme lo menos mal que pueda.

Mi deseo fuera dar Mapas particulares de cada Provincia, ó uno general, que las comprendiese todas; pero, esto, ademas de la im. posibilidad en las circunstancias de abrir aqui las láminas, tiene una suma dificultad, si han de ser, no digo exactas, mas aun pasaderas. Para hacer un Mapa exacto es mensster una colección de observaciones astronómicas de la longitud, y latitud de cada lugar. Con éllas se hace bien, y ibrevemente un Mapa. Todos los lugares se colocaran por \$i mismos en su debido punto; esto es en la interseccion de un Meridiano, y un Paralélo. Yun Mapa assi famás tendrá necesidad de corrección. ¿Pero como se hârá estoen un Reyno, donde hasta aqui no hay observaciones, á excepcicn de algunos lugares de sus costas, y aun de essas algunas bien dudosas?cienliverdadVqueoun Mapa con toda esta perfoccion, si es de un Pais grande, acaso no le hay. Ni para las necesidades ordinarias se pide que sea de una exactitud tan grande. Con tener las longitudes, y latitudes de los principales parages, y poblaciones del Reyno, o de cada Provincia, tuvieramos bastante. La colocacion de los menos principales se haría por las medidas itinerarias, - Ahuja. Pero, como hemos dicho, casi nada hay de esto. Y estas dificultades, que se encuentran para hacer un Mapa de este Reyno, no se superôrán nunca, mientras el Rey no destinare algunos sugetos instruidos, que caminando sus Provincias con los instrumentos, y cuidado necesarios hagan las observaciones, que se desean para esta obra; indagando al mismo tiempo, el origen, y curso de los Rios, y Cordilleras, como también, principalmente los limites de cada Prcvincia.

Por falta de todo esto no se halla todavía un Mapa razonable de esta América. Los de Sanson, y los del Isle son bien defectuosos. Los Roberto Vaugondi de los años de 1741, y el de su Hijo del año de 1751 
no tienen menos defectos. El de Mons. Anville, que es el mas célo bre, por estar hecho con las noticias, y documentos de Mons. Bouguer, la Condamine, y Maldonado, y sobre otros Mapas particulares, no lo tendrá por ajustado qualquier que haya viajado por este Reyno. A la primera vista encontrará en él no pocos errores sobre la posicion, y colocacion de los lugares. Ademas de esto ninguno tiene los límites de las Provincias, ni de los Obispados, ni, lo que es mas, de los distritos de las Audiencias. Todo por falta de observaciones, y noticias.

Estas razones dan bien á entender que esta relacion ó descripcion, que me propongo, es preciso que sea sucinta, no pudiendo dar un noticia mas extensa de la situación de los lugares. Pero podrá servir de plan, para que se perfeccione con el tiempo con nuevas averiguaciones, y nuevas noticias. En esto no hago mas que obedecer á una superior insinuacion del mejor modo, que me es posible por ahora; y que logre el público estas noticias, que por muchos titulos podran servir de instruccion á los curiosos, juntandolas á las que se dieron el año próximo pasado de 1763 en el Catálcgo histórico de los Virreyes de este Reyno.

\section{Biblioteca de Letras

